UNIVERSIDADE DE SÃO PAULO

FACULDADE DE FILOSOFIA, CIÊNCIAS E LETRAS DE RIBEIRÃO PRETO PROGRAMA DE PÓS-GRADUAÇÃO EM EDUCAÇÃO

EDUARDO HENRIQUE DE OLIVEIRA

\title{
MOTIVAÇÃO NAS AULAS DE EDUCAÇÃO FÍSICA: PERSPECTIVA DOS ALUNOS DO ENSINO FUNDAMENTAL
}




\title{
MOTIVAÇÃO NAS AULAS DE EDUCAÇÃO FÍSICA: PERSPECTIVA DOS ALUNOS DO ENSINO FUNDAMENTAL
}

\author{
Versão Corrigida \\ (Versão original encontra-se na unidade que aloja o Programa de Pós-graduação)
}

Dissertação apresentada ao Programa de PósGraduação em Educação da Faculdade de Filosofia, Ciências e Letras de Ribeirão Preto, Universidade de São Paulo como requisito parcial para obtenção do título de mestre em Educação.

Área de Concentração: Educação

Orientadora: Prof. ${ }^{a}$ Dr. ${ }^{a}$ Myrian Nunomura 
AUTORIZO A REPRODUÇÃO E DIVULGAÇÃO TOTAL OU PARCIAL DESTE TRABALHO, POR QUALQUER MEIO CONVENCIONAL OU ELETRÔNICO, PARA FINS DE ESTUDO E PESQUISA, DESDE QUE CITADA A FONTE.

Oliveira, Eduardo Henrique

Motivação nas aulas de Educação Física: perspectiva dos alunos do ensino fundamental. Ribeirão Preto, 2018.

117 p. : il. ; $30 \mathrm{~cm}$

Dissertação de Mestrado, apresentada ao programa de mestrado em educação da Faculdade de Filosofia Ciências e Letras de Ribeirão Preto da Universidade de São Paulo/USP. Área de concentração: Educação.

Orientador: Nunomura, Myrian.

1. Educação Física Escolar. 2. Motivação. 3. Educação Física e Saúde. 4. Educação. 
Nome: OLIVEIRA, Eduardo Henrique

Título: Motivação nas aulas de Educação Física: perspectiva dos alunos do ensino fundamental

Dissertação apresentada à Faculdade de Filosofia, Ciências e Letras de Ribeirão Preto da Universidade de São Paulo para obtenção do título de Mestre em Educação.

Aprovado em: 04/12/2018

Banca Examinadora

Prof. Dr ${ }^{\mathrm{a}}$. Mariana dos Santos Moretto Moreschi

Instituição: Prefeitura Municipal de Ribeirão Preto

Julgamento: Aprovado

Prof. Dra ${ }^{\mathrm{a}}$. Camila de Moraes

Instituição: Escola de Educação Física e Esporte de Ribeirão Preto

Julgamento: Aprovado

Prof. Dr. Rafael Pombo Menezes

Instituição: Escola de Educação Física e Esporte de Ribeirão Preto

Julgamento: Aprovado 


\section{DEDICATÓRIA}

Aos meus pais pelo incondicional amor, carinho e apoio durante todos os meus passos acadêmicos. Eles que são exemplo para minha vida e que mesmo nas horas mais difíceis jamais fraquejaram, mas me mostraram que o caminho da honestidade e dos estudos é o mais gratificante e precioso que o ser humano pode construir. 


\section{AGRADECIMENTOS}

Àquele que me permite a cada dia abrir olhos e realizar todos os meus desejos e compromissos. A Ele que me deu o dom da vida e me proporciona forças quando o caminhar parece tão árduo e difícil. Meu Deus, e Senhor da minha vida, que me faz ter a certeza da vitória e me faz acreditar que eu tudo posso se Nele confiar.

Em especial, àquela que me deu a oportunidade e confiança de conquistar este momento. Orientou não só este trabalho, mas também os meus passos nessa nova trajetória acadêmica. A ela que foi sentimento de calma e paciência quando precisei e me estendeu a mão para realização de um sonho profissional e pessoal. Professora Dr. ${ }^{a}$ Myrian Nunomura, os meus mais sinceros agradecimentos pelo aceite para com meu projeto e admiração à sua pessoa pela capacidade, humildade e amor com seus orientandos.

À minha avó e ao meu avô (este in memorian), que em suas simplicidades e pouco estudo sempre conheceram os meus sonhos e viram meu esforço, o meu amor e meu muito obrigado pelas orações. Aos meus pais, que sempre me apoiaram e acreditaram no meu potencial.

Às amizades que fiz durante essa minha caminhada, incluindo a pessoa maravilhosa Fernanda Martins Pereira que tanto me animou nos momentos conturbados. Aos meus amigos do Grupo de Estudos e Pesquisa em Aspectos Socioculturais e Pedagógicos do Esporte (GEPESPE-RP) com os quais aprendo a cada dia.

A todos os docentes e funcionários que tive o prazer de conhecer durante o processo de desenvolvimento da pesquisa. Também à banca examinadora que tanto contribuiu para a conclusão e refinamento deste trabalho.

Aos meus mestres de graduação que tanto me deram apoio e incentivaram para continuar o meu traço na vida acadêmica.

Aos professores e amigos que me ajudaram durante o processo de pesquisa e tornaram este sonho possível: Professora Maria Renata Junqueira e Cristiana Aparecido de Souza Oliveira, que contribuíram para que as entrevistas ocorressem e com materiais para enriquecer este estudo.

Aos meus amigos, que tiveram importância nessa minha caminhada acadêmica, em especial aos mais próximos: Glaucia de Fazio, Janaína Bavaresco, Pedro Jacinto, Juliana Faramiglio, Ana Silvia, Clarice Nascimento, Filipe Risso, Aline Tosta e Mariana dos Santos.

Por fim, agradeço a vocês e todos que comigo estiveram durante meu trabalho. 


\section{RESUMO}

A Educação Física (EF) é uma disciplina curricular obrigatória no sistema educacional e uma das aulas mais almejadas e prazerosas na perspectiva dos alunos. Ao longo dos anos, a EF sofreu diversas transformações, de disciplina com caráter higienista, voltado aos cuidados do corpo e ao militarismo, passou por uma fase tecnicista, na qual o foco era o desenvolvimento e aprimoramento das técnicas e do físico para competições. Porém, atualmente, além das práticas esportivas, a EF possui seu enfoque para o lazer, a saúde e a formação de um cidadão autônomo e reflexivo. Devido a sua relação com a saúde, é função da EF escolar promover programas e aulas que demonstrem ao aluno a importância da prática de atividade física/esporte relacionada aos hábitos de vida saudáveis, de modo que conheçam seu próprio corpo, executem atividades diárias com facilidade e evitem complicações gerais para a saúde futuramente. Ao longo dos anos, percebe-se a perda de interesse dos alunos em praticar as aulas com a mesma veemência dos anos iniciais, fato que se observa principalmente a partir do $6^{\circ}$ ano do Ensino Fundamental, quando os alunos se entretêm com outras atividades que não seja a prática de exercício físico/esporte. Devido à relevância desse fato, é importante investigar sobre a motivação desses alunos e compreender a falta de entusiasmo para as aulas de EF. A motivação caracteriza-se por estar movido a fazer algo, que pode ser caracterizada como intrínseca, isto é, inerente à prática (por prazer), ou extrínseca ligada a fatores externos. Nesse contexto de desmotivação dos alunos para com a EF, e sendo ela de potencial impacto à saúde, o objetivo desse estudo foi analisar a motivação dos alunos do Ensino Fundamental para as aulas de EF. Além disso, compreender a significância da disciplina para os alunos e como ela é percebida em sua relação com a promoção da saúde e qualidade de vida. A pesquisa se fez importante para conhecer a perspectiva dos alunos e trazer reflexões para melhoria do cenário que se encontra a EF escolar. O estudo utilizou a abordagem qualitativa, com entrevistas semiestruturadas, das quais participaram alunos do $9^{\circ}$ ano do Ensino Fundamental de uma escola municipal de Ribeirão Preto/SP. Para análise dos dados foi utilizada a análise temática. Foi possível compreender diversos fatores que impactam na motivação dos alunos, como: conteúdos, ações do professor, experiências ligadas ao contexto social (família e práticas esportivas) e aspectos voltados para a saúde. Identificou-se que o cenário das aulas de EF dessa instituição não se configura motivador e, para os alunos, o significado da disciplina se resume às práticas esportivas e a um "tempo livre". O professor foi muito citado como agente responsável por promover ou não uma aula diferenciada e motivadora, e a saúde reconhecida pelos entrevistados como fator importante e interligado às aulas. A motivação apresentou-se como um desafio para a EF, com a responsabilidade de diversos agentes que compõem o campo educacional, a fim de formar um cidadão transformador dessa prática perante a sociedade.

Palavras-chave: Educação Física Escolar; Motivação; Educação Física e Saúde; Educação. 


\begin{abstract}
Physical Education (EF) is a compulsory curricular discipline in the educational system and one of the most desired and pleasurable classes in the students' perspective. Over the years, EF underwent several transformations, from discipline with a hygienist character, focused on the care of the body and militarism, went through a technical phase, in which the focus was the development and improvement of the techniques and the physique for competitions. However, nowadays, in addition to sporting practices, EF has its focus for leisure, health and the formation of an autonomous and reflective citizen. Due to its relation to health, it is the function of the school EF to promote programs and classes that demonstrate to the student the importance of practicing physical activity / sport related to healthy living habits, so that they know their own body, perform daily activities with ease and avoid general health complications in the future. Over the years, students have lost interest in practicing classes with the same vehemence of the initial years, a fact that is observed mainly from the 6th year of elementary school, when students entertain themselves with other activities that do not be it the practice of physical exercise / sport. Because of the relevance of this fact, it is important to investigate the motivation of these students and understand the lack of enthusiasm for EF classes. Motivation is characterized by being moved to do something, which can be characterized as intrinsic, that is, inherent in practice (for pleasure), or extrinsic linked to external factors. In this context of students' lack of motivation towards EF, and being of potential impact on health, the objective of this study was to analyze the motivation of Elementary School students for EF classes. In addition, understand the significance of the discipline for students and how it is perceived in its relationship with health promotion and quality of life. The research became important to know the perspective of the students and to bring reflections to improve the scenario that is the school EF. The study used the qualitative approach, with semi-structured interviews, in which students from the 9th grade of elementary school from a municipal school in Ribeirão Preto / SP participated. Thematic analysis was used to analyze the data. It was possible to understand several factors that impact students' motivation, such as content, teacher actions, experiences related to the social context (family and sports practices) and aspects related to health. It was identified that the scenario of EF classes of this institution is not motivating and, for the students, the meaning of the discipline is reduced to sports practices and a "free time". The teacher was highly cited as the agent responsible for promoting or not a differentiated and motivating class, and the health recognized by the interviewees as an important factor and interconnected to the classes. The motivation presented itself as a challenge for the EF, with the responsibility of several agents that compose the educational field, in order to form a citizen transforming this practice before the society.
\end{abstract}

Key-words: School Physical Education; Motivation; Physical Education and Health; Education. 


\section{SUMÁRIO}

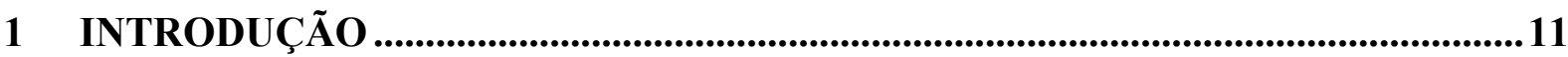

2 OBJETIVOS......................................................................................................................14

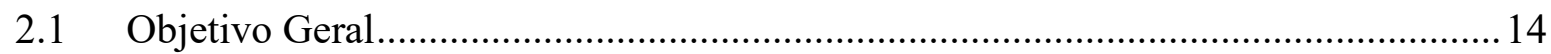

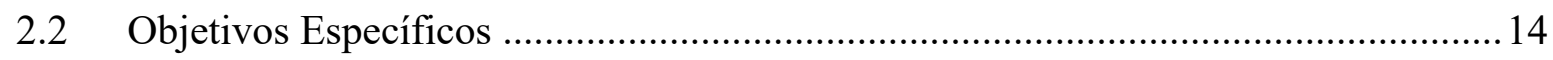

3 JUSTIFICATIVA...........................................................................................................14

4 REFERENCIAL TEÓRICO.........................................................................................15

4.1 Educação Física no Brasil: Breve Contexto Histórico...................................................15

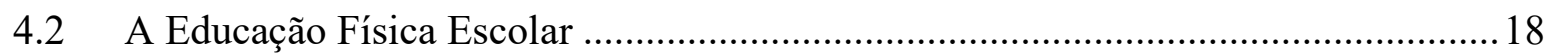

4.3 A Educação Física escolar em uma dimensão sociológica .............................................25

4.4 As abordagens pedagógicas da Educação Física …………………………………....22

4.5 A Educação Física na rede de ensino Estadual de SP e no Município de Ribeirão Preto 33

4.6 A Criança e o Adolescente na fase escolar ....................................................................40

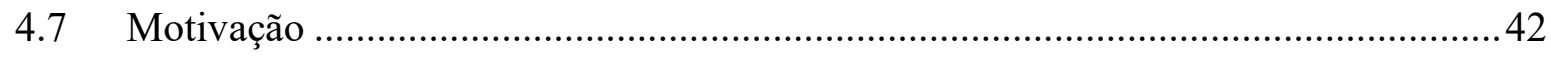

4.7.1 Teorias da Motivação ………………………………………………………......4

4.7.2 A motivação e a educação física escolar .................................................................4

4.8 Promoção da Saúde na Educação ……………………………………………….......52

4.8.1 A Saúde no contexto da Educação Física escolar..................................................54

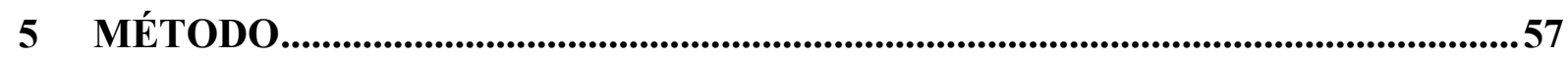

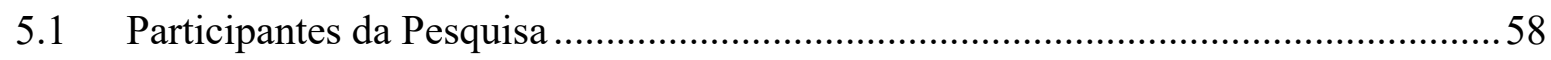

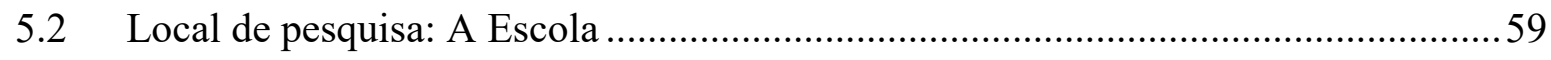

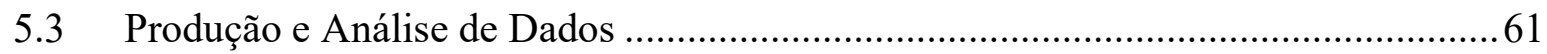

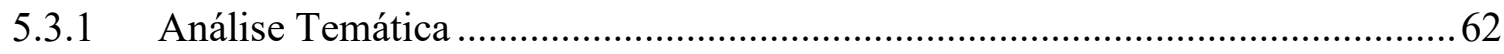

6 RESULTADOS................................................................................................................65

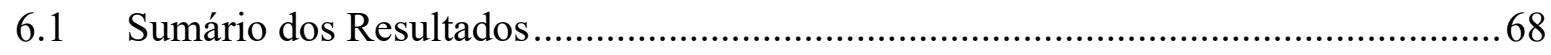

6.2 Representatividade da Educação Física Escolar: tempo livre e práticas esportivas ..71 


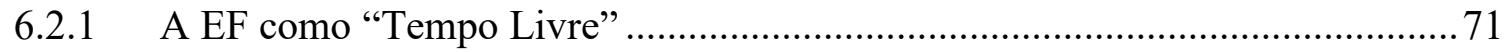

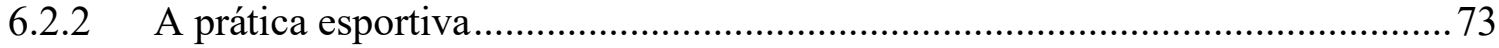

6.3 O conteúdo da aula: "aula livre", conteúdo dirigido e o papel do professor.............78

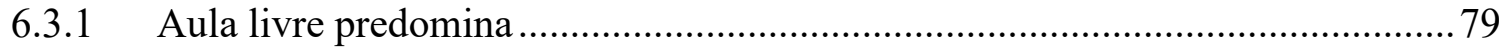

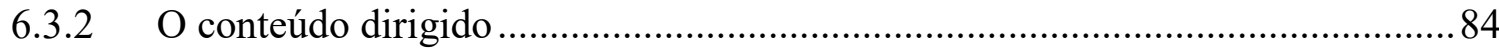

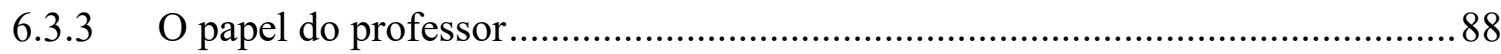

6.4 A família e as vivências no esporte. ................................................................. 92

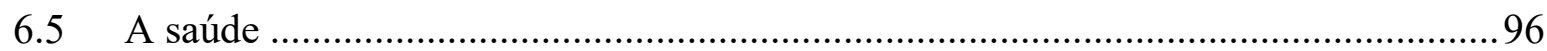

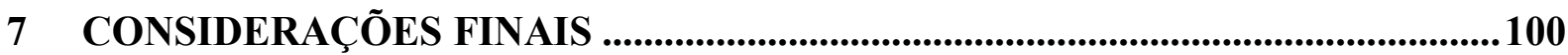

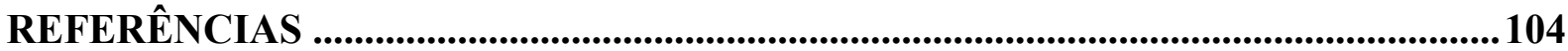

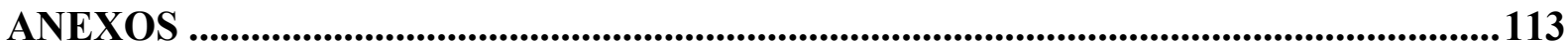

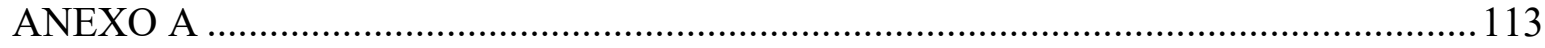

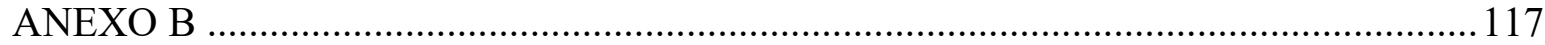




\section{INTRODUÇÃO}

A Educação Física (EF) é uma disciplina presente na grade curricular do Ensino Fundamental em nosso país, e sua obrigatoriedade no ensino foi reforçada pela Lei 10.328 de 12 de dezembro de 2001, devendo ajustar-se às faixas etárias e às condições da população escolar, e tornou-se facultativa em cursos noturnos (BRASIL, 2001).

Para muitos estudantes, as aulas de Educação Física remontam uma ideia prazerosa e divertida, manifestada pelo interesse e satisfação pessoal em praticar modalidades coletivas e individuais, que envolvam conquistas, jogos e brincadeiras. Contudo, outros nutrem uma ideia não muito boa, amarga e descontente dessas aulas, mostram-se desmotivados por razões que vão desde a preferência dos amigos em colegas mais habilidosos até pelas formas como os professores abordam os conteúdos ou conduzem a disciplina (MARZINEK, 2004).

Assim, há uma proposta dos Parâmetros Curriculares Nacionais (PCNs) para diversificar e democratizar a prática pedagógica na EF, com a finalidade de que ela desenvolva, tanto a corporeidade, como também dimensões afetivas, cognitivas e socioculturais dos alunos (BRASIL, PCNs EDUCAÇÃO FÍSICA, 1997). A proposta do documento é que a área atinja, por meio da cultura corporal, condições crítico-reflexivas sobre o ambiente, seus hábitos de vida e não apenas se limite a disputas esportivas ou sentimentos amargos da disciplina.

A realidade na prática das aulas é outra e, muitas vezes, difere do que preconizam documentos como os PCNs, a legislação e outras diretrizes. Quando falamos em motivar e despertar alegria e interesse em aula, envolvem-se diversos fatores, como: ambiente, conteúdo, experiência profissional, etc. E, manter diversos alunos motivados por um longo tempo, é uma tarefa não muito simples para muitos professores.

Ao longo dos anos, percebe-se que, as crianças e os jovens começam a perder o interesse nas aulas de Educação Física e, aquela aula que parecia divertida e prazerosa para eles torna-se desinteressante. Fato que podemos perceber com mais veemência nas séries finais do Ensino Fundamental (correspondentes do $6^{\circ}$ ao $9^{\circ}$ ano) e no Ensino Médio, sendo comum vê-los durante as aulas apenas sentados e conversando, mexendo em dispositivos móveis ou ainda entretidos com outra atividade que não seja a prática de exercício físico na aula (DARIDO, 2004).

Sobre a desmotivação dos alunos, um estudo de Cavalieri (2012), com alunos do Ensino Médio, ressalta sobre a evasão dos alunos nas aulas de EF, pois a proposta esportivista 
não vem ao encontro das expectativas e os conteúdos se fazem repetitivos. Tenorio e Silva (2013) reforçam que a repetição de conteúdo, o predomínio do universo esportivo (as formas didáticas como é proposto) e o foco em outras prioridades de vida (como vestibular ou mercado de trabalho) afastam os alunos da vivência da EF escolar.

A motivação impulsiona os indivíduos a realizarem algo que lhes desperte o interesse. Atualmente, sua ausência é fato nas aulas de EF, e os alunos e professores consideram a atividade como algo complementar e a deixam em segundo plano. O sistema escolar contribui para que a EF seja vista como uma disciplina menos rígida, com menos importância à prática de atividades corporais e foco intelectual nas demais disciplinas (TENORIO; SILVA, 2013).

Em vista disso, perpetua-se a falta da motivação intrínseca, isto é, segundo Ryan e Deci (2000) aquela que impulsiona o indivíduo determinado a praticar atividade por puro prazer e a recompensa é inerente à prática, promove a autoestima e resulta aprendizado de alta qualidade e criatividade. Em contrapartida, os autores ressaltam que a motivação extrínseca se baseia no incentivo externo à prática, uma recompensa ou obtenção de resultados, ou seja, relacionada a fazer algo que leva a um resultado separável. Os motivos extrínsecos podem estar relacionados à resistência e desinteresse em realizar a ação ou impulsionado por atitude que reflete a aceitação de um valor.

A prevalência da motivação extrínseca nas aulas de EF resultaria na perda desse interesse pelas aulas. $\mathrm{O}$ entusiasmo vai se perdendo na medida em que a prática não possui significância para o aluno, e ele passa a executá-la apenas por obrigação. A partir do momento em que o jovem cumpre a disciplina apenas por fazer parte do seu cotidiano escolar, para cumprir o currículo imposto, e não há enriquecimento de aprendizado com as aulas, são necessárias propostas inovadoras que revertam esse quadro (MARZINEK, 2004). O ambiente social e as diferenças individuais proporcionam necessidades às pessoas e esse fato possui impacto na motivação. Os desafios tendem o indivíduo para a autodeterminação, e os resultados satisfatórios deixa-o motivado intrinsicamente. Porém, se houver sentimento de pressão, ansiedade ou ausência de determinação ele está motivado extrinsecamente (RYAN; DECI, 2000). Estratégias que reforcem o interesse intrínseco precisam ser realizadas para fixação da aprendizagem e da conquista pessoal por parte dos alunos.

É importante frisar que, atualmente, as crianças e a juventude vivem um bombardeamento de tecnologias e atrativos eletrônicos, bem como incentivos para hábitos alimentares não muito saudáveis e cheios de alimentos hipercalóricos e ricos em gorduras. É claro que esses fatores contribuem muito para o aumento do sedentarismo e causam danos para jovens menos interessados em praticar atividades físicas. 
Assim, o ambiente escolar torna-se essencial e propício para a promoção da saúde, bem-estar e qualidade de vida. Neste contexto e por meio da Educação Física, presente como disciplina curricular, os estudantes podem ser conscientizados sobre hábitos de vida saudáveis e estilo de vida ativo (com a prática regular de exercícios).

Ferreira (2001) salienta que os exercícios físicos melhoram os níveis de colesterol, reduzem os distúrbios cardiovasculares, aumentam a vascularização, reduzem a ansiedade, a depressão e podem combater a obesidade. Tais problemas de ordem fisiológica, como: ansiedade, depressão e obesidade são comuns e visíveis na adolescência, contudo podem ser reduzidos com a prática regular de exercícios físicos e hábitos alimentares saudáveis. Assim, “cumpre à educação física escolar criar nos alunos o prazer e o gosto pelo exercício e pelo desporto, de forma a levá-los a adotar um estilo de vida saudável e ativo" (FERREIRA, 2001, p.44).

A EF escolar é a própria atividade física inserida no cotidiano dos alunos e com o objetivo de desenvolver toda a parte corporal e também a conscientização para a saúde e cuidados com o corpo.

Portanto, este estudo, de caráter qualitativo, com foco no ambiente escolar, visa verificar o cenário de interesse ou não dos alunos pelas aulas de EF, a perspectiva motivacional, e a relação com a promoção da saúde corporal.

Visamos com isso contribuir para a área escolar, para que tenham uma Educação Física diferenciada, de qualidade, atraente e motivadora, a fim de provocar a reflexão dos professores e demais profissionais envolvidos que poderiam aprimorar este cenário.

A melhoria da EF escolar desde a base do ensino se faz importante para nossas crianças e jovens, pois impactam nas demais dimensões humanas ao longo da vida, por exemplo, na mudança de hábitos saudáveis no cotidiano. 


\section{OBJETIVOS}

\subsection{Objetivo Geral}

Analisar a motivação dos alunos do Ensino Fundamental para as aulas de Educação Física.

\subsection{Objetivos Específicos}

Compreender os fatores que impactam no nível de motivação dos alunos na Educação Física escolar e a significância das aulas de Educação Física e sua representatividade para os alunos que encerram o ciclo do ensino fundamental.

Identificar a relação da conscientização da saúde com a motivação dos estudantes e se por meio dela seria possível aprimorar e sugerir intervenções para a prática da disciplina.

\section{JUSTIFICATIVA}

A realização deste estudo se justifica pelo quadro de desmotivação nas aulas de EF que se observa em alunos dos anos finais Ensino Fundamental $\left(6^{\circ}\right.$ ao $9^{\circ}$ ano $)$ ao longo de sua trajetória escolar. Nesse cenário, enxerga-se uma situação preocupante com a geração de um público sedentário em idade tão importante para o desenvolvimento pessoal e incorporação de hábitos saudáveis para a vida.

A EF é uma disciplina associada ao desenvolvimento físico, motor, afetivo, sociocultural e também à saúde. Assim, apesar de sua importância para crianças e jovens, a EF escolar não tem aplicado seus reais objetivos, necessitando de uma prática motivadora e significativa para os educandos.

Portanto, a pesquisa faz-se necessária para compreender o quadro desmotivador para a prática da EF escolar e o que poderia ser sugerido para reverter essa situação.

É pertinente também o legado e a contribuição da pesquisa para a literatura existente, pois tem potencial para suscitar novas investigações e reflexões para os profissionais da área escolar. Além disso, a melhor maneira de compreender e aprimorar esse cenário é atuar ao agente principal do contexto e a oportunidade ao aluno de se expressar sobre as aulas, reforça 
o legado de importância que ele possui como agente protagonista da EF escolar e como cidadão transformador da sociedade.

\section{REFERENCIAL TEÓRICO}

\subsection{Educação Física no Brasil: Breve Contexto Histórico}

A atividade física se faz como necessidade prática do ser humano desde os primórdios, seja para seu prazer ou para sobreviver em meio às dificuldades impostas pela vida cotidiana (MOREIRA, 2009), ou seja, atividades que visam a busca por qualidade de vida que se observa em nossa sociedade.

No contexto atual, a Educação Física $(E F)$ é relacionada à saúde, lazer e práticas esportivas, porém, na primeira metade do século XX, no Brasil, ela era vista pelos setores do Estado e pelo exército como uma atividade estritamente militar (CASTRO, 1997).

Assim, a história nos mostra que a Educação Física traz um vínculo com as instituições militares, um conceito de disciplina e cuidado com o corpo. A introdução da Educação Física no Brasil teve forte influência da França, essa que "durante toda a segunda metade do século XIX, a chamada 'corrente francesa' de educação física foi dominada pelos militares e caracterizada justamente por seu marcante “espírito militar”" (CASTRO, 1997, p. 4).

A história da EF remonta aos tempos do Brasil Império e dos primeiros momentos do período Republicano e com várias citações que a vinculam às instituições militares, tais como: a criação da Escola Militar pela carta Régia; a introdução da Ginástica Alemã; a fundação da missão militar francesa; a criação do Centro Militar de EF e também o fato de os militares terem formado os primeiros professores civis de EF (CASTELLANI FILHO, 1988).

A EF teve forte influência dos métodos ginásticos europeus, dentre eles o alemão, sueco, francês e inglês. O primeiro possuía fortes tendências médico-higienistas que visava doutrinar os civis em defesa da pátria, além do preparo do corpo para o mercado de trabalho, possuía um caráter militar patriótico e a formação de homens fortes e robustos. O método sueco tinha um viés de manutenção da saúde e combate dos vícios presentes na sociedade, formar homens trabalhadores que preservassem a paz e a família. O método francês vinha de 
um caráter filosófico e ideias liberais, chegou ao Brasil no início do século XX, com concepções de "ginástica como remédio" e a prática da calistenia. Por fim, o inglês trouxe a universalização dos esportes e das regras, tendência esportivizada que teve grande influência nas décadas de 40 e 70 (no século XX) e influenciam a EF até hoje (SOARES, 2007).

No Brasil, a EF era extremamente defendida pelos médicos como "remédio" para os males da sociedade que disciplinava o corpo e a moral e garantiam a manutenção do poder. Caracterizava-se por uma educação do físico, somada à concepção de "superioridade racial", em uma sociedade biologizada (SOARES, 2007).

Ainda no século XIX, a EF era valorizada para promover um indivíduo forte, saudável, com vistas ao desenvolvimento do país e para sair de sua condição de colônia. Porém, esse caráter de educar o físico e voltado à saúde corporal não foi algo exclusivo dos militares, pois junto com eles estavam os médicos que visavam à formação da "nova família" por meio da conduta moral, física e intelectual que se opunha à estrutura colonial (CASTELLANI FILHO, 1988).

No início de 1929, um anteprojeto de lei do general Nestor Sezefredo Passos tornou a EF obrigatória em todos os estabelecimentos de ensino, federais, municipais e particulares, a partir da idade de seis anos e para ambos os sexos. Com esse anteprojeto, os militares invadiram a escola e tiveram a EF como instrumento para intervenção educacional e social do país (CASTRO, 1997). Castellani Filho (1988) nos confirma o fato ao ressaltar a adoção da EF por parte dos militares como maneira de formar cidadãos fortes e saudáveis para defenderem a pátria. E, esse ponto nos remonta às influências do método alemão destacada por Soares (2007).

Portanto, instala-se, na EF brasileira o caráter higienista, com meta em um físico saudável e pouco suscetível a doenças, e também a preocupação com a eugenia, que visava manter a "pureza" da raça branca. Contudo, o trabalho e o esforço físico não eram vistos com bons olhos pela elite, devido à associação com os serviços escravos. Assim, a prática de atividades físicas na escola sofria resistência e não era obrigatória (BRASIL, PCNs EDUCAÇÃO FÍSICA, 1997). Como Castellani Filho (1988) reforça, a preocupação com a eugenia, com uma EF voltada à educação sexual de homens e mulheres a serem responsáveis em manter a raça "pura" e de "qualidade" da raça branca. Entretanto, a elite imperial era resistente por assimilar a prática de atividades físicas ao trabalho escravo.

No Brasil, foi nessa década de 30 que o exército passou fortemente a ser o principal idealizador e que comandava movimentos a favor da EF, que visava ao patriotismo e ao treinamento militar. Com o Decreto n. 69.450, de 1971, considerou-se a EF como a atividade 
que desenvolve e aprimora forças físicas, morais, cívicas, psíquicas e sociais do educando. Tinha-se a iniciação esportiva a partir da quinta série para busca de talentos que competissem e representassem internacionalmente o país (BRASIL, 1997).

“O 'adestramento físico' era mencionado como forma de preparar a juventude para 'o cumprimento de seus deveres para com a economia e a defesa da nação"” (CASTRO, 1997, p. 11). Assim, acentuava-se um extremo autoritarismo e patriotismo no país, no qual a Educação Física era o canal de preparação para o físico saudável e de disseminação de ideologias vinculadas à padronização de raças (eugenia).

Segundo Castro (1997), a única crítica que havia era da igreja e, mesmo assim, apenas sobre aspectos morais e não políticos, tais como ela era difundida na escola em questões materialistas, promiscuidade dos sexos, etc. Porém, durante o Estado Novo, a Educação Física era inquestionável e em grande parte os professores eram os militares.

Em 1937, na elaboração da Constituição, incluíram-na no currículo como uma prática educativa obrigatória em todos os estabelecimentos de ensino (BRASIL, PCNs EDUCAÇÃO FÍSICA, 1997). Fato esse ocorrido durante o governo provisório de Getúlio Vargas que criou, na década de 30, o Ministério da Educação e Saúde Pública, o qual estava sobre o domínio dos militares no que se refere à EF (CASTRO, 1997).

A EF utilizava a ginástica para preparar a mulher para a maternidade ou para promover a socialização, não sendo permitidos esforços fora das condições do seu corpo. Ao inserir a EF na escola, essa passou também a ser responsável por esse desenvolvimento da mulher como mãe, e a ginástica era permitida para ambos os sexos (CASTELLANI FILHO, 1988). É importante destacar dessa época que o papel do homem era muito mais valorizado que o da mulher, o que caracterizava muito a figura patriarcal, inclusive, na $\mathrm{EF}$.

A EF, ainda em meados dos anos 30, foi voltada para fortalecer trabalhadores e melhorar a produção nas indústrias devido ao processo de industrialização. Porém, o esporte só ganhou seu espaço com a Lei de Diretrizes e Bases de 1961, que obrigou a disciplina nos ensinos primário (antiga classificação para o atual ensino fundamental) e médio.

Castellani Filho (1988) nos recorda a era tecnicista da EF de 1964, em que se visava ao desenvolvimento do aluno em caráter técnico e físico para promover mão de obra qualificada. Logo após esse período, sob o regime militar em nosso país, retomou-se a questão da "Ordem e Progresso", que voltou a formação da EF para a questão de segurança e um indivíduo forte e saudável ligado ao exército. Posteriormente, na década de 80 , houve algumas mudanças em que a disciplina foi inserida também na pré-escola, com enfoque no 
desenvolvimento psicomotor da criança, e extrapolou até os limites biológicos e de rendimento.

Diante desse contexto histórico brasileiro da EF, diretrizes confirmam que os modelos que se adotavam vieram ser questionados também devido ao Brasil não ter se tornado uma nação olímpica e começou a ser aplicada como disciplina também nas séries iniciais (de primeira a quarta) e o enfoque de preparo ao alto rendimento, o qual passou a ser o desenvolvimento psicomotor do aluno.

Considerada atualmente como uma área essencial na escola e com vários discursos e propostas para o desenvolvimento do aluno, a EF ainda é marginalizada, considerada de pouca importância por professores, gestores e outros profissionais da educação. Alocada em horários de contra turnos dos alunos, que não favorecem as suas especificidades ou que seja conveniente a outras áreas do conhecimento ou à instituição. É importante ressaltar que entre instituições, especialmente públicas e privadas, existem diferenças quanto à oferta da $\mathrm{EF}$, em questão de estruturas, benefícios e investimentos (quando há iniciativa privada). Porém, Severino e Adriano (2015) reforçam que a aproximação do ensino médio faz com que inclusive as escolas privadas priorizem algumas disciplinas para o vestibular, o que não inclui a EF na maioria dos casos.

Após conhecermos sobre o histórico da EF, a próxima sessão traz informações sobre a disciplina no ambiente escolar nos dias atuais: seus objetivos, obrigatoriedade, dificuldades, posição docente, propostas, entre outros.

\subsection{A Educação Física Escolar}

A EF é uma disciplina obrigatória na educação básica e integra a grade curricular do Ensino Fundamental em nosso país (BRASIL, 1996). Ela se difere das demais práticas físicas e esportivas experimentadas na escola à medida que integra a proposta pedagógica do ambiente escolar e, fazendo-se obrigatória, é ministrada por profissional legalmente licenciado e geralmente no turno regular (TEIXEIRA, 2015).

Visto que a Educação é um direito de todos assegurado pela legislação, e a EF uma disciplina integrante dessa Educação Básica, todos os alunos matriculados nas escolas de ensino fundamental possuem a obrigatoriedade e equidade de acesso a esse conhecimento (NISTA-PICCOLO; MOREIRA, 2012). 
A EF é tida como a própria atividade física inserida no cotidiano dos alunos e com o objetivo de desenvolver toda a parte corporal e também o preparo da mente. Trata-se da área de inserção e integração do aluno na cultura corporal, e esse usufrui de jogos, esportes, lutas, danças e ginásticas em prol do exercício da cidadania e da qualidade de vida (DARIDO, 2004). A EF faz o aluno se movimentar, define as relações do homem com a cultura do movimento, e visa promover a práxis social na comunidade em que está inserido (KUNZ, 2004).

Para reafirmar esses objetivos por meio dos Parâmetros Curriculares Nacionais (PCNs), a EF escolar propõe-se a favorecer a autonomia dos alunos em suas próprias atividades, regular o esforço, traçar metas, conhecer as potencialidades, limitações e o que pode ser prejudicial. Sendo assim, ela deve ainda contribuir para o desenvolvimento de todos os alunos, de forma não seletiva, visando ao aprimoramento como seres humanos (BRASIL, 1997). Por meio da EF o aluno pode conhecer seu próprio corpo a partir de práticas prazerosas, interagiria com professor e demais alunos. Em vista disso, seu papel se caracteriza em educar, socializar, motivar e proporcionar qualidade de vida saudável (SANTOS; DUQUE, 2010).

Os PCNs (1997) propõem que a EF promova na escola dimensões afetivas, cognitivas e socioculturais, a fim de formar cidadãos não apenas voltados aos aspectos físicos e de habilidades esportivas, mas um ser humano com potencialidades e consciente do seu papel na sociedade. É importante destacar diante de propostas para a disciplina que "Levar o aluno a conhecer, a querer e a praticar EF implica reconhecer fatores que interferem nas mudanças de comportamento, como os fatores biológicos, socioculturais e motivacionais" (NISTAPICCOLO; MOREIRA, 2012, p. 31). É preciso propor oportunidades que sejam agradáveis para realizar o exercício sistematizado na prática esportiva, condicionamento físico, ginástica e outros (NISTA-PICCOLO; MOREIRA, 2012).

Sobre os aspectos afetivos nessa proposta, deve ser contemplado o companheirismo, a inclusão, a aceitação e a melhora da autoestima, as potencialidades, os laços de amizades, dentre outros, e articulado ao Projeto Político Pedagógico (PPP) da unidade escolar. Também é preciso ter cuidado com a exposição do aluno, favorecer a inclusão de pessoas com deficiência, o respeito como algo primordial, alegria e responsabilidade. Em relação aos aspectos cognitivos, a EF pode promover o raciocínio lógico, a organização e intervenção de forma autônoma nos espaços, a elaboração de estratégias, o conhecimento sobre o próprio corpo e suas capacidades. Por fim, a contribuição para formar um cidadão reflexivo, construtor de sua cultura, é relacionada às dimensões socioculturais da proposta, nas quais por 
meio das aulas sejam trabalhados elementos de diversas manifestações culturais, tais como: aspectos históricos, danças de diferentes povos, lutas diversificadas, formas de manifestação de ginástica, etc., um vasto patrimônio cultural que contribui para uma postura não discriminatória e visa ao pleno exercício da cidadania por parte do aluno (BRASIL, PCNs EDUCAÇÃO FÍSICA, 1997).

Como componente curricular, a EF deve proporcionar ao aluno a introdução e a integração da cultura corporal do movimento para produzir, reproduzir e transformá-la, formar um cidadão por meio do usufruto de jogos, danças, ginásticas e outras práticas em prol da qualidade de vida (BETTI; ZULIANI, 2002). Além disso, a EF escolar deveria despertar nos alunos, após as aulas formais e dirigidas, a autonomia da prática de atividades físicas regulares sem o auxílio de especialista, e encontrar uma prática prazerosa (DARIDO, 2004).

Em suma, as aulas devem ampliar a cultura e o conhecimento científico dos alunos, pois além das informações compartilhadas pelo docente, é essencial que se permita o estímulo pela busca de novos conhecimentos que transcendam as experiências da aula (MOREIRA, 2009).

Atualmente, a proposta da EF escolar é proporcionar ao aluno o pleno exercício da cidadania, a concepção da cultura corporal, o desenvolvimento da autonomia, a cooperação, a afirmação de valores e os princípios democráticos. Em vista disso, é possível elencar alguns aspectos importantes que a disciplina se propõe a cumprir, ou seja, por meio dos conteúdos, visa que o aluno conheça atividades lúdicas e esportivas como direito e necessidade de todos; o conhecimento sobre o corpo, hábitos de boa alimentação e higiene corporal também devem estar inclusos no cronograma das aulas; por meio de aulas mistas, os alunos aprendem a tolerância em relação às diferenças de gênero com boa convivência e respeito às diversidades; o respeito às regras também deve ser trabalhado, juntamente com a questão da não violência no jogo e a questão ilícita do consumo de substâncias prejudiciais à saúde (BRASIL, PCNs EDUCAÇÃO FÍSICA, 1997).

Autores como Moreira (2009) vão um pouco além do que dizem os PCNs e ressaltam que a EF hoje, forma e capacita o aluno por meio de vivências corporais que exigem além de movimentos, mas por meio delas ele se torne independente e construa o conhecimento. Assim, a aula não se resume em aquecer, jogar e alongar, mas é preciso que exista ação, reflexão, discussão e crítica, e agregue valores e capacidade ao educando de promover suas escolhas e tarefas.

Da mesma forma que os PCNs propõem a EF voltada à cultura corporal, tendências surgiram para ampliar o trabalho da disciplina e romper com uma visão unilateral e 
tradicionalista. Essas tendências seguem caminhos da psicologia, sociologia, saúde e proporcionam um vasto campo de trabalho a partir do que se denomina de abordagens da EF.

Por volta da década de 80 e 90, surgiram abordagens como: ConstrutivistaInteracionista, Crítico-Superadora, Cultural, Sistêmica e outras. Muitas foram proveitosas para repensar a prática, porém, com pouco impacto de mudanças no cotidiano das aulas. Até mesmo com o surgimento dos PCNs (no final dos anos 90), citado já no estudo em relação aos objetivos e propostas da disciplina, é pouco usado por professores, pois esses não acreditam na aplicabilidade do que é proposto à realidade local, contudo, muitos desses docentes não se dão ao trabalho de conhecer ou ler o documento (MOREIRA, 2009).

O documento seria para orientar o professor em seu planejamento curricular, contudo, ele reduz a autonomia dos professores e não considera a diversidade das escolas para os temas sugeridos. Além disso, é difícil considerar um conhecimento básico e geral que o documento preconiza com diversos contextos regionais e saber quais critérios usar para a seleção de conteúdos em detrimento de outros, pois vivemos grande influência de avaliações externas (FERRAZ; CORREIA, 2015).

Em vista disso, o estudo de Camacho e Almeida (2008) debatem os PCNs, e ressaltam que os documentos e diretrizes elaboradas pelo governo consideram a sociedade como harmônica, homogênea e ignora as contradições e as diferenças regionais. Tal posição configura-se como instrumento de poder que percebe apenas os problemas gerais e não considera a realidade que professores e alunos estão inseridos.

Rodrigues (2002) discorre sobre os PCNs voltados a EF e critica o caráter superficial que os temas trazem para o aluno sobre a indústria esportiva, a mídia e o consumismo do esporte para o pensamento crítico e reflexivo, com exemplos que não apontam a realidade de exclusão social e desigualdades econômicas presentes no país. A autora ainda ressalta que a superação das contradições do documento pode ser encontrada no próprio opressor, isto é, em seu conteúdo, a partir de reflexões e identificação das exigências do processo de globalização.

Assim, um documento que rege tanto os temas do currículo não só da EF como das demais disciplinas, vale considerar e refletir sobre sua aplicação nas aulas em meio às críticas realizadas. Contudo, é importante ressaltar que os PCNs são de caráter propositivo e não obriga as escolas a aderirem e, portanto, apesar de inúmeras críticas, tem sido a principal diretriz de escala nacional pelos professores (NETO; TEIXEIRA, 2017).

Segundo Betti e Zuliani (2002), a matemática, as ciências, as línguas, e outras são áreas do saber científico e erudito que se desenvolveram isoladamente. Por outro lado, a Educação Artística, a antiga Educação Moral e Cívica e a Educação Física não se enquadram 
nesses limites e ocupam hoje um lugar incômodo na Escola, o que leva ao questionamento de suas finalidades. Assim, desde meados de 1920, a tradição aponta, a EF como uma atividade complementar e isolada nos currículos escolares, com objetivos voltados mais ao treinamento pré-militar, eugenia, nacionalismo, preparação de atletas, etc. E, apesar da EF apresentar esgotamento, nos últimos anos houve crescimento da prática esportiva, porém, com maior ênfase no consumo em "assistir o esporte" do que praticá-lo, ou seja, ainda como espectador ou apreciador.

É pertinente lembrar também que, para muitos, as aulas de EF remontam uma ideia prazerosa, divertida, com vitórias e brincadeiras, porém, outros nutrem uma ideia não muito boa, amarga e descontente dessas aulas (BRASIL, PCNs EDUCAÇÃO FÍSICA, 1997).

Essa ideia de prazer e de ser uma das disciplinas favoritas ocorre por ser um espaço menos rígido que o da sala de aula. Contudo, o predomínio de valores competitivos e o universo esportivo como conteúdo principal presentes na cultura da EF escolar ainda carrega essa ideia de experiência negativa para alguns alunos que se sentem menosprezados e inferiorizados ante aqueles que são mais habilidosos (TENORIO; SILVA, 2013).

A proposta dos PCNs se configura em algo bom e proveitoso para se trabalhar, porém, difere um pouco em sua aplicabilidade na prática do cotidiano escolar. Atualmente, as escolas brasileiras, e não só no ensino público, enxergam a EF como disciplina complementar, com importância secundária no currículo da escola. Ela é vista como disciplina à margem perante as demais, e sendo assim, há um desencadeamento de problemas como a não aplicabilidade de conteúdos como propostos nos PCNs.

Pinto (2011) confirma esse fato de que a EF não é plenamente presente nas escolas particulares, por não ser contemplada no vestibular, e nas escolas públicas muitas vezes é ignorada, não cumprindo seus objetivos e tampouco utilizando o espaço que lhe compete. Faz, portanto, uma crítica destacando que não se alfabetiza apenas com Português e Matemática, mas também as demais disciplinas têm suma importância na formação, como a Educação Física, que contribui para a prática da cidadania, discussões de regras, autodisciplina, competição, etc.

No próprio documento dos PCNs da EF é reconhecida essa marginalidade na disciplina, que acaba atingindo inclusive o docente que se convence de que sua disciplina não é valorizada, distancia-se da equipe pedagógica e acaba desenvolvendo um trabalho isolado (BRASIL, PCNs EDUCAÇÃO FÍSICA, 1997).

Em vista desse trabalho isolado encontram-se os problemas de aplicabilidade e desenvolvimento de programas propostos nos objetivos da EF. Os professores acabam por 
não se motivarem em promover aulas diferenciadas e, como afirmam Santos e Duque (2010), eles trabalham meritocracia em práticas esportivas, nas quais os mais habilidosos se destacam e não há variações para outros aprendizados. Esses dados mostram o que popularmente se conhece nas escolas como a política do "rola a bola". Dessa forma, temos nesse campo da EF, segundo a teoria de Bourdieu (1983), que as regras e a conduta, isto é, a "doxa" está pautada em quem tem mais habilidade para desenvolver as tarefas propostas pelo currículo, tornandoo legítimo no campo.

Moreira (2009, p. 99), diante de um panorama em que os PCNs dificilmente são seguidos e as abordagens não foram totalmente satisfatórias e de pouco avanço nas aulas de EF de forma geral, aponta propostas para (re)significar a área no ensino fundamental:

- A necessidade do processo de inclusão (articulado ao PPP), isto é, integrar aquele aluno que sente desgostoso com a aula, todos participando e superando seus obstáculos em suas condições;

- Problematização para gerar soluções, devendo o professor deixar que os alunos a partir de suas experiências motoras resolvam o problema de uma ação;

- Adaptação à diversidade dos alunos, ou seja, lembrar que os alunos são diferentes em suas capacidades e é preciso que a atividade seja adequada e significativa para eles e não o inverso;

- Meios de comunicação e tecnologia como recurso, isto é, utilizar da mídia como recurso reflexivo e crítico para que o aluno analise o meio esportivo como um cidadão não alienado;

- Corresponsabilidade pela prática, que neste caso diz respeito à relação estabelecida com o professor e sua turma. O conteúdo não deve ser de domínio apenas do docente, mas é preciso analisar a necessidade, realidade e gostos dos alunos com os quais se está trabalhando.

É uma proposta que, em meio a linhas escritas, se faz muito satisfatória e pertinente para o avanço da EF no ambiente escolar, contudo, é preciso ter compromisso do professor e da instituição de trabalho, bem como conhecer toda essa realidade que abordamos aqui por diversos autores sobre a realidade da disciplina. Nesse contexto que se vive da EF, encontram-se diversas dificuldades que têm perdurado por anos, seja dispensa das aulas, falta de interesse, concepções equivocadas dos objetivos da aula, entre outras.

Darido (2004) possui trabalhos na investigação da EF escolar com alunos que não participam das aulas, e ressalta que muitos que pedem a dispensa dessas alegam transmissão 
de pouco ou nenhum conhecimento, da falta de interesse dos professores, falta de material ou até mesmo prática de atividade em outros locais. Baseado nesse fato, é difícil perceber a concretização dos objetivos da EF que consta na legislação e nos PCNs.

Os conteúdos predominantes nas aulas de EF são as práticas esportivas, sendo as mesmas na preferência de muitos alunos, por fatores como a influência da mídia ou por se destacarem em suas habilidades em alguma modalidade, contudo, outras atividades devem ser trabalhadas, pois é apontada por muitos estudantes a baixa qualidade nas aulas, sempre repetitivas, sem criatividade e que sempre destacam o papel do vencedor (DARIDO, 2004). Nessa perspectiva, Ferreira (2001) confirma essa repetição de atividades e afirma que, no Brasil, a EF é a única disciplina que aplica os mesmos conteúdos desde a $5^{\text {a }}$ série (atualmente $6^{\circ}$ ano pela reforma do ensino de nove anos) até o Ensino Médio. Para tanto, o autor pede que essa comprovação seja feita e propõe visitas às escolas, públicas ou privadas, consulta aos alunos ou mesmo no resgate de nossas próprias aulas. Além da repetição, é importante que a progressão pedagógica de tais conteúdos seja repensada.

Martinelli et al. (2006) estudaram alunas do Ensino Médio que indicaram desagrado no conteúdo da EF, que se caracteriza apenas em forma de jogo, com destaque para: vôlei, handebol, basquetebol e futebol. Foi apontada a falta de exercícios de fundamentos, falta de aquecimento de outras atividades como, dança e ginástica. Alguns professores "pegam" a bola, jogam para os alunos e não há o aprendizado prévio dos movimentos que auxiliem na situação do jogo.

Sendo assim, muitos conteúdos e objetivos sugeridos na EF escolar ainda estão à margem da aplicabilidade, assim como a própria disciplina. Os professores são ainda muito influenciados pela concepção esportivista e as modalidades tradicionais predominam ainda como conteúdo principal das aulas, sem sistematização, de forma aleatória e sem critérios (PEREIRA; SILVA, 2010). Farias et al. (2017) em estudo quantitativo com alunos no ensino fundamental, destacam $83 \%$ de apontamentos às práticas esportivas como conteúdo principal das aulas e que define a EF com uma cultura ainda esportivista. Conteúdos que deveriam ser contemplados como: dança, ginástica e lutas ficam apenas na vontade dos alunos.

Diante dessas considerações, atualmente os professores desenvolvem suas aulas com conteúdos pré-selecionados em livros e esportes, não valorizam a participação do aluno e isso se configura apenas como transmissão do conhecimento, que ocorre devido à herança cultural tecnicista. Existe resistência a mudanças nas práticas pedagógicas da EF, e os docentes ainda insistem na teoria voltada para o esporte e melhora de aptidão física (SILVA et al., 2010). 
Sendo assim, este cenário educacional nos remete a refletir como a EF é entendida pelos estudantes, sendo uma disciplina de suma importância e pode nos ajudar a entender a questão motivacional a qual este estudo propõe. Vale destacar que o contexto históricocultural da EF tem grande importância para o enriquecimento da reflexão e melhor compreensão da área, portanto, no próximo item será abordada a EF a partir de uma visão na sociologia.

\subsection{A Educação Física escolar em uma dimensão sociológica}

Em uma abordagem sociológica pela teoria de Pierre Bourdieu, todo campo social é aquele caracterizado por uma disputa de poder para alcançar o que se é legítimo dentro desse determinado campo, proposto por regras e normas que o autor denomina de "doxa" do campo.

Essa busca por legitimidade está em torno dos agentes que compõem o campo, no caso das aulas de EF, os alunos buscam a ascender nesse campo e cumprir o que propõe a "doxa" para se tornar legítimo (BOURDIEU, 1983). Sendo assim, cumprir as tarefas propostas de forma mais eficiente possível caracteriza-o como bom aluno e habilidoso na disciplina.

Assim, a EF escolar é considerada, em dimensão sociológica, como um campo social que possui uma estrutura legitimada e com disputa por poder entre os agentes envolvidos, ou seja, toda comunidade escolar (BOURDIEU, 1983).

Ainda falando do campo, ele não é uma estrutura fixa, ou seja, os agentes atuam conforme suas posições e podem conservar ou mudar sua estrutura. Atrelado ao campo está o conceito do "habitus", que é definido como disposições em perceber, fazer ou agir de determinada forma em uma dada circunstância. Sendo assim, o campo estrutura o "habitus" e o "habitus" constitui o campo (THIRY-CHERQUES, 2006).

O aluno, principal agente do campo na EF escolar, possui então o "habitus", ou seja, sistemas de esquemas de percepção e apreciação das práticas que refletem características do meio em que foi socializada (BOURDIEU, 1996). Uma estrutura, estruturante e estruturada, isto é, algo que foi construído pelas disposições e ações no campo e que poderá se transformar com novas interações.

A EF escolar, como um campo social, possui sua "doxa" pautada nos documentos oficiais, legislações, e planos de ensino que regem e moldam a educação brasileira, dentre eles podemos citar: Leis de Diretrizes e Bases (LDBs) como a 9.394/96, os PCNs da EF; Plano Político Pedagógico de cada escola; o plano de aula do professor; etc. Bourdieu ressalta que 
os agentes não questionadores desta "doxa" visam mantê-la para garantir sua legitimidade e são considerados ortodoxos. Por outro lado, os questionadores e visualizadores, de outras formas de ascensão no campo seriam os heterodoxos (BOURDIEU, 1983).

Além da "doxa" e do "habitus" que estão entrelaçados ao campo social da EF, a contribuição dessa disciplina proporcionará a aquisição de diversos conhecimentos que são importantes na vida dos indivíduos (os agentes), os quais foram denominados por Bourdieu de capitais. Ao longo da construção do "habitus", o aluno vai acumulando os capitais, isto é, formas de trabalhos acumulados que podem ser materializadas ou incorporadas e proporcionariam poder e legitimidade no campo em questão.

Os capitais são classificados pelo autor em: o capital social, que se configura nas relações com os demais agentes; o capital econômico, que são a posse de bens e poder monetário; o capital cultural, o qual possui três formas, sendo ele incorporado (conhecimento adquirido ao longo da vida), objetivado (bens culturais ou materiais) ou institucionalizado (certificações) (BOURDIEU, 1986). Cabe ressaltar, portanto, que a escola, bem como a EF, objeto desse estudo, é um espaço institucional em que há presença do capital cultural e sua construção, principalmente, em relação ao objetivado e institucionalizado, os quais presumem que o sujeito possua o incorporado e o transforme em suas interações.

Ao observar o ambiente da EF escolar, Darido (2005) destaca que existe forte tendência ao esporte como principal conteúdo e, principalmente, no que se refere aos mais conhecidos mundialmente (basquete, vôlei e futebol), aplicados muitas vezes de forma descontextualizada. Dado esse levantado pela autora, nos faz refletir que se forma uma "doxa" nos ambientes que isso ocorre (as escolas), e o "habitus" do agente é construído de forma que seu capital cultural relacionará a EF ligada fortemente ao âmbito esportivo e distanciando dos demais fatores que a disciplina envolve.

Ao analisar essa dimensão sociológica, a EF é uma disciplina em que a construção do "habitus" do indivíduo se manifesta de diferentes formas e é muito influenciada pela cultura do local em questão, ou seja, da instituição e dos agentes ministrantes (os professores). Para entendermos a questão da cultura é pertinente destacar o que Bourdieu (1996) afirma sobre a cultura ser conteúdo substancial da educação, sua fonte e sua justificação última, assim uma não pode ser pensada sem a outra. Desse modo, é preciso compreender que a cultura de um local está ligada às interações e como o aprendizado se desenvolve naquele contexto e campo, uma vez que tudo isso ocorre ao longo do tempo (na história).

Ao se abordar o conceito de campo, a EF escolar se configura em uma cultura relacionada ao local em questão, em que é destacada a teoria da aprendizagem cultural e da 
cultura de aprendizagem. A primeira teoria permite compreender que a interação com o ambiente evolui o "habitus" do agente, cria novos horizontes ou até mesmo cria limites prospectivos. Seria o modo que o ambiente propicia que os indivíduos se apropriem dos conhecimentos (às vezes de forma tácita ou intencional) daquele espaço, em virtude do "habitus" e da posição do indivíduo no referido campo (BARKER-RUCHTI et al., 2016). As culturas de aprendizagem estão relacionadas com o campo e os conhecimentos apropriados e reproduzidos pelos agentes por meio das interações (HODKINSON; BIESTA; JAMES, 2007).

Portanto, o aprendizado pode variar de acordo com o campo em questão (nesse caso a escola), com a legitimidade do campo e como foram construídas culturalmente as aulas de EF desse local, bem como da bagagem cultural e do "habitus" que os agentes expostos a essas aulas trarão em sua interação.

Este campo da EF escolar traz uma série de abordagens de ensino, cada qual com sua característica e proposta para a melhoria da aplicabilidade de conteúdos e preparação pedagógica para o ensino da EF na escola. No próximo item de sessão será elucidado um pouco sobre essas abordagens.

\subsection{As abordagens pedagógicas da Educação Física}

É importante ressaltar que as abordagens surgiram no plano da EF escolar para romper com o modelo mecanicista (ou esportivista em que impera a influência do esporte na EF), de aprender apenas técnica voltada ao esporte e renovar de forma teórico-prático os conhecimentos em EF. Em suma, elas objetivam o foco não apenas no aprender a fazer, mas na ação (como fazer) do professor que proporcione significado à prática do aluno, ou seja, entender o porquê de realizar determinadas atividades, além de transmitir valores da cultura corporal do movimento (SILVA et al., 2010). Azevedo e Shigunov (2000) ressaltam essa renovação teórico-prático que busca uma nova dimensão, que vai desde os conteúdos e elementos específicos até o procedimento de avaliação dos alunos na EF.

A primeira abordagem é a desenvolvimentista. Preconiza a aplicação da aprendizagem alinhada à sequência de desenvolvimento das habilidades, para que os conteúdos não fiquem além nem aquém das capacidades reais da criança. Assim, a EF deve possuir seus objetivos em função das mudanças de comportamento do indivíduo, respeitam características afetivasemocionais, habilidades, conhecimento, etc. Há, por exemplo, a necessidade de aquisição de 
habilidades básicas para evitar problemas em desenvolver e aprender habilidades específicas e complexas (TANI et al. 1988).

A partir da proposta dos autores outros estudos como Silva et al. (2010) expressam que o movimento é o principal condutor dessa abordagem, ou seja, a aprendizagem de movimentos simples e complexos promoverá interação com o indivíduo responsável em desenvolver seu comportamento motor. "Preconiza para a EF que seja proporcionado ao aluno condições para que seu comportamento motor seja desenvolvido através da interação do aumento da diversidade e da complexidade de movimentos" (AZEVEDO; SHIGUNOV, 2000 , p. 4). Os autores ainda citam que os movimentos devem respeitar o estágio de crescimento e desenvolvimento da criança (em foco dos 4 aos 14 anos) para que se alcancem as habilidades. Contudo, há de se considerar que acompanhar o desenvolvimento de cada aluno torna-se uma tarefa difícil para o professor que adota essa abordagem, pois geralmente trabalha-se em salas numerosas com alunos em diferentes ritmos de desenvolvimento e aprendizagem.

A abordagem construtivista-interacionista, traz Freire (1989) como idealizador e destaca que as experiências corporais que as crianças necessitam para compreender o mundo devem estar presentes na escola e ser significativas para elas, isto é, experiências que condizem com sua realidade, trabalhando cultura infantil e utilizando do conhecimento que a criança já possui. É a abordagem que prepara a EF como um caminho para que o aluno atinja o desenvolvimento cognitivo. Para tanto, o movimento funciona como canal de aprendizagem para aspectos cognitivos como lógica, leitura, escrita, dentre outros (SILVA et al. 2010). A partir de suas vivências e experiências com o mundo, o aluno construirá seu conhecimento. Por meio da EF e a utilização de jogos, brincadeiras populares, com regras bem definidas e interação com objetos desenvolve-se o componente cognitivo e a capacidade de resolução de problemas no indivíduo (FREIRE, 1989). Nessa abordagem as experiências e a cultura do aluno devem ser valorizadas, a atividade lúdica com tarefas cada vez mais complexas e os jogos são os principais meios para se ensinar (AZEVEDO; SHIGUNOV, 2000).

A próxima é uma abordagem ressaltada por Darido (1998) como crítico-superadora, e se baseia no marxismo e é influenciada por autores como José Libaneo e Dermeval Saviani, tendo como oposição o modelo mecanicista. É uma proposta diagnóstica que pretende ler os dados da realidade, interpretá-los e emitir juízo, seus idealizadores são Castellani Filho, Valter Bratch, Carmen Soares e outros estudiosos da área que levantam questões de poder, interesse, esforço e contestação. É a abordagem que possui o conhecimento como forma de mediação entre a construção do aluno e a realidade social complexa em que vive, tendo a cultura 
corporal como parte constituinte dessa realidade e que as atividades voltadas ao movimento sejam realizadas de forma crítica e transformadora não algo isolado apenas no mecânico da técnica (COLETIVO DE AUTORES, 1992).

Em relação aos conteúdos, deve ser considerada sua relevância social, contemporaneidade e características sócio-cognitivas dos alunos, bem como eles devem ser trabalhados de maneira aprofundada ao longo dos anos, sem a visão de pré-requisitos. Nesse contexto, o conhecimento não é transmitido, mas proporcionada ao aluno a possibilidade de criar seu pensamento crítico, assimilar e contextualizar fatos. Assim, a EF fica entendida como a disciplina que aborda a cultura corporal do movimento (com jogos, esporte, dança, ginástica e capoeira) (AZEVEDO; SHIGUNOV, 2000). A cultura corporal na escola não é apenas para ser reproduzida, mas para ser apropriada criticamente e por meio dela o estudante exercer sua cidadania e papel consciente na sociedade (BRACHT, 1999).

A abordagem crítico-emancipatória é proposta e idealizada por Kunz (2004) desde 1994, com o propósito de superar o trabalho e interesse técnico na área da EF (em especial de esportes) e assumir um propósito crítico-emancipatório. Tem-se como exemplo, a proposta do ensino do atletismo aos alunos com formas não de mensurar ou superar seus rendimentos, mas de desenvolver, emancipar seu movimento e se divertir. Além disso, é importante destacar a proposta de superar as injustiças sociais, e ensinar o esporte como meio de contribuir ao jovem para a reflexão crítica e emancipatória (SILVA et al. 2010). Reflete o ensino do esporte para transformar o aluno em um ser crítico e questionador de diversas realidades, bem como desconstruir a imagem do esporte como algo negativo e puramente tecnicista (AZEVEDO; SHIGUNOV, 2000).

$\mathrm{Na}$ tentativa de romper com o modelo esportivista, nessa abordagem o aluno descobrirá formas de participar em atividades do movimento, expor pela linguagem o que aprenderam e experimentaram e, por fim, aprender a questionar suas descobertas e entender a cultura da aprendizagem (DARIDO, 2003). Utiliza-se de uma didática que envolva trabalho, interação e linguagem e desenvolvem-se os objetivos da EF: propor situações problemas e escolha das atividades (trabalho), trabalho em grupo com os colegas para superação de limites e medos (interação) e a expressividade do aluno na forma verbal, seja por fala, comemoração ou até mesmo gritos e vibrações (linguagem) (KUNZ, 2004).

$\mathrm{Na}$ abordagem sistêmica o aluno é visto como um ser social que sofre constante influência do meio e dos que o cercam, é uma abordagem que não se ampara em uma única resposta, mas visa integrar e introduzir o indivíduo em sua cultura física, para que ele possa usufruir, compartilhar e transformá-la (BETTI, 1991). "Existe a preocupação de garantir a 
especificidade, na medida que considera o binômio corpo/movimento como meio e fim da Educação Física escolar" (DARIDO, 2003, p. 10). A habilidade não é o foco principal como ainda destaca a autora Darido (2003), é preciso que o aluno compreenda o significado de toda a atividade e como tirar o melhor proveito dela. É preciso conhecer as consequências de determinado exercício e como ele influenciará no cotidiano, saber em um esporte além da habilidade para conquistar o ponto, mas como se organizar socialmente para jogar, respeitar as regras e o adversário dentre outros. Ela é um sistema hierárquico aberto que influencia e também sofre influência da sociedade.

Segundo Azevedo e Shigunov (2000), é uma abordagem que evidencia como é importante para o aluno entender os motivos pelo qual pratica a atividade e que essa seja para ele positiva em conquistas materiais, afetivas e sociais. Betti (1991) principal idealizador da abordagem, coloca o caráter sociológico e que pudesse atender às necessidades pedagógicas e contrapor uma EF que apresenta um cenário de fatores como: aulas reduzidas às práticas do futebol, um esporte escolar elitizado e reprodutor, professores despreparados e desmotivados, dentre outros. Além disso, o autor a considera um sistema hierárquico aberto que sofre influência e ao mesmo tempo influencia a sociedade. A partir do conceito de cultura física o aluno não busca na EF a melhoria de suas habilidades, mas entende o movimento como uma discussão mais ampla e reflete os propósitos e aspectos positivos na sua prática (BETTI, 1994).

Outra abordagem que não é só indicada na EF, mas também para a psicologia, psiquiatria, neurologia e orientação educacional é a da psicomotricidade. É uma das teorias que visa o aprendizado da criança por meio de processos cognitivos, afetivos e psicomotores, para garantir uma formação integral. Le Boulch (1992) destaca que a educação psicomotora desenvolve a consciência corporal no indivíduo, auxilia na aquisição da lateralidade e coordenação para os movimentos que pratica por meio dos processos de assimilação e acomodação. Nessa perspectiva, o professor precisa ser consciente de que não possui apenas responsabilidades técnicas e esportivas, mas também pedagógicas (DARIDO, 2003). De acordo com Azevedo e Shigunov (2000), deve se utilizar do componente lúdico para que o desenvolvimento e a aprendizagem sejam impulsionados. Essas aprendizagens devem ser significativas, exploratórias e espontâneas da criança em suas relações interpessoais.

A abordagem cultural vem para criticar o processo biológico que norteia a EF e a visão do corpo humano como um conjunto de ossos, músculos e articulações. O corpo é produto da cultura na qual está inserido e por meio dela seu significado é expressado. Apesar de possuírem a mesma composição, os corpos não são iguais e assim as aulas de EF por 
trabalharem esse corpo e sua forma de expressão no cotidiano também não podem ser a mesma para todos em qualquer época e lugar (DAOLIO, 1997). A cultura se difere, portanto, a técnica de cada aluno também, pois é resultante de aprendizagem específica de uma sociedade. Nessa abordagem, sugere-se que o professor leve em consideração todo repertório e bagagem cultural do seu aluno e sem julgar a técnica como correta ou mais adequada (DARIDO, 2003).

Azevedo e Shigunov (2000) afirmam que o movimento é considerado uma técnica construída culturalmente em um grupo social, sem a existência do movimento certo ou errado. O movimento produzido pelo aluno é fruto da história do seu corpo e do contexto social que ele está inserido. Sendo assim, Daolio (1997) ressalta que desvincular o homem da sua cultura é algo impossível e nas aulas de EF devem-se trabalhar conteúdos ligados à sua realidade e contexto cultural sem impedir inclusive que eles expressem movimentos ligados às suas histórias de vida, aprendizados e experiências que são produtos de suas respectivas culturas.

A próxima é a abordagem dos jogos cooperativos, na qual Brotto (1995) que é autor referência no Brasil sobre esta ideia, destaca o ponto em que a participação de todos é importante, sem que haja exclusão por habilidade, que exista interação de grupos e divertimento entre os participantes. O importante não é o resultado, o fato de vencer ou obter sucesso mediante a competição, e sim obter prazer com a diversão e estar unido. Nesses jogos, o intuito não é a superação ou eliminação de um grupo, mas a percepção que todos os alunos devem possuir de unidade e companheirismo para se atingir determinado objetivo. Os jogos cooperativos são algo transformador, divertido, com valores humanitários em que todos experimentam o sentimento de vitória sem promover a exclusão (SILVA, et al. 2010).

A abordagem intitulada como saúde renovada, busca conscientizar sobre os benefícios da atividade física para a qualidade de vida. Promover aulas que não se baseiem em aspectos esportivos ou desenvolvimento e aprimoramento de habilidades, mas organizar experiências que proporcionem aos educandos um estilo de vida fisicamente ativo e os incentivem a adotálo na vida adulta (GUEDES; GUEDES, 1993). Nahas (1997) corrobora ao propor e entender os objetivos da EF em ensinar aos alunos a relação da atividade física com a saúde e seus benefícios para ao longo da vida, nutrindo hábitos alimentares saudáveis e prática costumeira de exercícios.

É importante destacar seu aspecto voltado para a questão da saúde e qualidade de vida, e visa promover a atividade física para estimular funções fisiológicas (cardiovascular, respiratória, hormonal etc.), capacidades físicas (força, resistência, flexibilidade, etc.) e composição corporal para melhoria da saúde e benefícios no cotidiano do ser humano. A 
autora ainda frisa que nas décadas de 70 e 80 esse foco biológico da EF, para investigar níveis de força, resistência e outros não tinha como objetivo o ambiente pedagógico. Contudo, com o passar dos anos esse caráter biológico da EF começou a ser levado para dentro da escola, a fim de romper com o caráter higienista e eugenista presentes na época. Para concluir, essa abordagem visa reverter a incidência de distúrbios orgânicos pela falta de atividade física, e ensinar ao aluno conceitos básicos da prática regular de exercícios com a aptidão física ligada à saúde (DARIDO, 2003). Dentre todas, atualmente uma das mais relevantes pelo estado físico das crianças e relação com a vida adulta e adiante.

Por fim é importante destacar os Parâmetros Curriculares Nacionais (PCNs), já citados neste trabalho, inclusive como referência bibliográfica de conceitos e objetivos da EF na escola. Este não se configura uma abordagem, mas traz contribuições para mudanças na EF escolar. Devido à relevância desse documento, Darido (2003) destaca sua elaboração iniciada em 1994 e seu lançamento em 1997, 1998 e 1999 para o ensino fundamental ciclos I e II e ensino médio, respectivamente. Eles vieram como proposta de democratização do ensino da EF e para ampliar a visão não apenas biológica, mas social, cultural e afetiva. Os PCNs enfocam a EF para desenvolver o currículo das escolas que dialogue com propostas já existentes e forme um aluno participante de atividades corporais, que pratique atitudes respeitosas, de dignidade e se torne um cidadão crítico-reflexivo.

Todas essas abordagens que norteiam a área da EF surgiram ao longo da história, e a maioria permeia até hoje nas escolas. Mesmo com o surgimento dos PCNs há de se notar dentro de seu conteúdo e na própria caracterização de seus objetivos muitas outras abordagens implícitas. Cada uma possui características importantes para as aulas de EF, e visa ao desenvolvimento do aluno e qualidade das aulas e muitos professores, em escolas particulares, adotam diferentes dessas abordagens ao longo do ano como destacam os resultados do estudo de Silva et al. (2010), outros tendem a seguir apenas uma (como os próprios PCNs) e em escolas estaduais muitos nem conhecem ou adotam essas abordagens.

Se existe a melhor ou mais adequada, é importante lembrar que todo aluno possui sua história de vida, seu contexto social, assim como a escola em que essas aulas acontecem possui sua cultura, então, essas abordagens precisam ser refletidas pelos docentes antes de serem adotadas na prática.

$\mathrm{Na}$ sessão seguinte, será abordado como a EF se molda nas escolas municipais de Ribeirão Preto, a qual uma delas faz parte desta pesquisa, bem como na rede estadual de ensino (no estado de São Paulo) em que se localiza este município. 


\subsection{A Educação Física na rede de ensino Estadual de SP e no Município de Ribeirão Preto}

A Educação, mesmo tendo os mesmos princípios e deveres para com a comunidade em diversos âmbitos do país, possui consideráveis diferenças quando falamos de currículo, organização e até mesmo público atendido nas esferas estaduais e municipais. Assim, será abordado aqui como ocorre, em específico, a EF nas escolas da rede estadual de São Paulo e do município de Ribeirão Preto/SP (local de realização da pesquisa).

No currículo escolar do Estado de São Paulo a Educação Física está presente como disciplina da área de linguagens, códigos e suas tecnologias. Esse documento reforça a importância do sujeito estar inserido em diferentes culturas que não dissociam do corpo, movimento e intencionalidade (SÃO PAULO, PROPOSTA CURRICULAR, 2008).

Assimilando-se ao que afirma os PCNs da Educação Física, o documento que trata sobre a disciplina no estado afirma: “... Educação Física trata da cultura relacionada aos aspectos corporais, que se expressa de diversas formas, dentre as quais os jogos, a ginástica, as danças e atividades rítmicas, as lutas e os esportes" (SÃO PAULO, CURRÍCULO DO ESTADO, 2011, p. 224).

A partir da $5^{\text {a }}$ série (atualmente $6^{\circ}$ ano) do Ensino Fundamental (anos finais), a disciplina deve evidenciar significado e sentido nas experiências proporcionadas aos alunos, isto é, explicar o sentido e a intencionalidade dos aprendizados nas culturas esportiva, lúdica, gímnica, de lutas e ritmos (SÃO PAULO, CURRÍCULO DO ESTADO, 2011). A Proposta Curricular de São Paulo (2008) sugere a partir dos conhecimentos e experiências nos movimentos corporais já pertencentes ao aluno, a fim de ampliá-lo e qualificá-lo criticamente.

Os conteúdos desenvolvidos na Educação Física, para os anos finais do Ensino Fundamental, são indicados conforme quadro 1 a seguir:

Quadro 1 - Conteúdos da Educação Física para Ensino Fundamental anos finais da rede Estadual de SP.

\begin{tabular}{|c|c|l|}
\hline \multirow{4}{*}{$\begin{array}{c}\text { Conteúdos } \\
\text { para } 6^{0} \text { anos }\end{array}$} & $\begin{array}{l}\text { Jogos populares, cooperativos e pré-desportivos; } \\
\text { Esporticas }\end{array}$ & $\begin{array}{l}\text { Esportivas } \\
\text { bola }- \text { futebol ou handebol: técnicas, táticas, regras e histórico; } \\
\text { Modalidade Individual: ginástica artística ou rítmica - gestos } \\
\text { técnicos, regras e histórico. }\end{array}$ \\
\cline { 2 - 4 } & Lutas & Não especificado \\
\hline
\end{tabular}




\begin{tabular}{|c|c|c|}
\hline & $\begin{array}{l}\text { Atividades } \\
\text { Rítmicas }\end{array}$ & $\begin{array}{l}\text { Noções gerais sobre ritmos; } \\
\text { Jogos rítmicos. }\end{array}$ \\
\hline & Ginástica & Não especificado \\
\hline & $\begin{array}{l}\text { Conhecimento } \\
\text { do Corpo }\end{array}$ & $\begin{array}{l}\text { Capacidades físicas: noções gerais, agilidade, velocidade, } \\
\text { resistência, força e flexibilidade, alongamento e aquecimento; } \\
\text { Aparelho locomotor e seus sistemas; } \\
\text { Postura. }\end{array}$ \\
\hline \multirow{5}{*}{$\begin{array}{c}\text { Conteúdos } \\
\text { para } 7^{\circ} \text { anos }\end{array}$} & $\begin{array}{l}\text { Práticas } \\
\text { Esportivas }\end{array}$ & $\begin{array}{l}\text { Modalidade individual: atletismo (corridas e saltos); ginástica } \\
\text { artística ou rítmica; } \\
\text { - Princípios técnicos ou gestos técnicos, táticos, regras e histórico; } \\
\text { Modalidade coletiva: basquetebol ou voleibol; } \\
\text { - Princípios técnicos e táticos, regras, histórico. }\end{array}$ \\
\hline & Lutas & $\begin{array}{l}\text { Princípios de confronto e oposição; } \\
\text { Classificação e organização; } \\
\text { A questão da violência. }\end{array}$ \\
\hline & $\begin{array}{l}\text { Atividades } \\
\text { Rítmicas }\end{array}$ & $\begin{array}{l}\text { Manifestações representações da cultura rítmica nacional: } \\
\text { Danças folclóricas e regionais: histórico, a questão do gênero. }\end{array}$ \\
\hline & Ginástica & $\begin{array}{l}\text { Ginástica geral: Fundamentos e gestos, histórico: dos métodos } \\
\text { ginásticos clássicos à ginástica contemporânea. }\end{array}$ \\
\hline & $\begin{array}{l}\text { Conhecimento } \\
\text { do Corpo }\end{array}$ & $\begin{array}{l}\text { Capacidades físicas: aplicações em esportes coletivos, no } \\
\text { atletismo e atividade rítmica. }\end{array}$ \\
\hline \multirow{5}{*}{$\begin{array}{l}\text { Conteúdos } \\
\text { para } 8^{\circ} \text { anos }\end{array}$} & $\begin{array}{c}\text { Práticas } \\
\text { Esportivas }\end{array}$ & $\begin{array}{l}\text { Modalidade Individual: Atletismo (corridas e arremessos / } \\
\text { lançamentos) - princípios técnicos e táticos, regras, histórico; } \\
\text { Modalidade Coletiva: a escolher - Técnicas e táticas como fatores } \\
\text { de aumento da complexidade do jogo, noções de arbitragem. }\end{array}$ \\
\hline & Lutas & $\begin{array}{l}\text { Judô, karatê, taekwondo, boxe ou outra: Princípios técnicos e } \\
\text { táticos, regras, histórico. }\end{array}$ \\
\hline & $\begin{array}{l}\text { Atividades } \\
\text { Rítmicas }\end{array}$ & $\begin{array}{l}\text { Manifestações e representações da cultura rítmica de outros } \\
\text { países; } \\
\text { Danças folclóricas: histórico, a questão do gênero. }\end{array}$ \\
\hline & Ginástica & $\begin{array}{l}\text { Práticas contemporâneas: ginástica aeróbica, ginástica localizada, } \\
\text { princípios orientadores, técnicas e exercícios; } \\
\text { Ginásticas de academia; } \\
\text { Padrões de beleza corporal, ginástica e saúde. }\end{array}$ \\
\hline & $\begin{array}{c}\text { Conhecimento } \\
\text { do Corpo }\end{array}$ & $\begin{array}{l}\text { Capacidades físicas: aplicações no atletismo e luta; } \\
\text { Princípios e efeitos do treinamento físico; }\end{array}$ \\
\hline
\end{tabular}




\begin{tabular}{|c|c|c|}
\hline & & $\begin{array}{l}\text { Atividade física/exercício físico: implicações na obesidade e no } \\
\text { emagrecimento; } \\
\text { Substâncias proibidas: doping e anabolizantes. }\end{array}$ \\
\hline \multirow{5}{*}{$\begin{array}{l}\text { Conteúdos } \\
\text { para } 9^{\circ} \text { anos }\end{array}$} & $\begin{array}{l}\text { Práticas } \\
\text { Esportivas }\end{array}$ & $\begin{array}{l}\text { Modalidade coletiva: a escolher - técnicas e táticas e noções de } \\
\text { arbitragem; } \\
\text { Esporte na comunidade escolar; } \\
\text { Esporte na mídia e grandes eventos esportivos; } \\
\text { Jogo e esporte: diferenças; } \\
\text { Modalidade de outros países: rugbi, badminton e outros; } \\
\text { Organização de campeonatos. }\end{array}$ \\
\hline & Lutas & $\begin{array}{l}\text { Capoeira como luta, jogo e esporte: Princípios técnicos e táticos, } \\
\text { histórico. }\end{array}$ \\
\hline & $\begin{array}{l}\text { Atividades } \\
\text { Rítmicas }\end{array}$ & $\begin{array}{l}\text { Manifestações rítmicas na comunidade escolar e em seu entorno; } \\
\text { Manifestações rítmicas ligadas à cultura jovem: hip-hop, } \\
\text { streetdance e/ou outras: expressões, passos, coreografias; } \\
\text { Organização de festivais de dança. }\end{array}$ \\
\hline & Ginástica & Não especificado \\
\hline & $\begin{array}{l}\text { Conhecimento } \\
\text { do Corpo }\end{array}$ & Não especificado \\
\hline
\end{tabular}

Fonte: Proposta Curricular do Estado (2008).

A Resolução SE no 81 de 16 de dezembro de 2011, dispõe a aplicação desses conteúdos em aulas com a seguinte carga horária: duas aulas semanais, com duração de 50 minutos cada, em horário regular de funcionamento da classe e por um professor especialista (SÃO PAULO, 2011).

Em relação ao município de Ribeirão Preto, para os anos iniciais a EF está ligada à área de arte e movimento, na qual o aluno representa seu conhecimento baseado em suas experiências físicas, culturais e sociais. Para o trabalho específico de movimento é importante que o professor de EF (profissional habilitado) trabalhe o aprimoramento das potencialidades físicas, corporais e sociais do aluno (SECRETARIA DA EDUCAÇÃO, REFERENCIAL CURRICULAR, 2011). Para os anos finais (compreendendo de $6^{\circ}$ a $9^{\circ}$ ano), a disciplina fazse mais específica e visa garantir o acesso dos estudantes às práticas corporais, contribuir para a construção de um estilo pessoal de exercê-las e oferecer instrumentos para que sejam capazes de apreciá-las criticamente (SECRETARIA DA EDUCAÇÃO, REFERENCIAL, 2017). 
O documento municipal que contempla os anos finais ressalta as competências da EF que as aulas devem proporcionar aos alunos, tais como: participar de atividades corporais, estabelecendo relações equilibradas e construtivas com os outros; respeito mútuo e solidariedade nas atividades lúdicas e esportivas; conhecer e desfrutar da manifestação da cultural corporal do país e do mundo; adotar hábitos saudáveis de higiene, alimentação e atividades corporais; saber regular suas possibilidades de esforço e perseverar no desenvolvimento de competências; conhecer e saber refletir e criticar os padrões de beleza e estética; desenvolvimento da autonomia (SECRETARIA DA EDUCAÇÃO, REFERENCIAL, 2017). Todos remetem ao que também propõe os PCNs em relação à disciplina.

Os conteúdos são trabalhados e selecionados nas concepções conceitual, procedimental e atitudinal, e mesmo nos últimos anos e com um resgate histórico a EF, tenha priorizado apenas a questão procedimental, então, é preciso que em seu planejamento o professor reflita e aplique as demais dimensões. Nessa perspectiva, a EF deverá apresentar os conteúdos nas três dimensões, respeitando as particularidades e prioridades da escola e dos alunos (SECRETARIA DA EDUCAÇÃO, REFERENCIAL, 2017).

Essas dimensões em que se baseia o ensino da EF municipal de Ribeirão Preto são propostas por Zabala (1998) que define cada dimensão com uma pergunta para melhor compreensão e com propósito de alcançar as finalidades educacionais. Sendo assim, o autor ressalta que o conceitual está relacionado à questão "o que se deve saber? ", o procedimental seria “o que se deve saber fazer?" e por fim o atitudinal "como se deve fazer?".

Darido e Souza Junior (2015) explicam tais dimensões relacionadas ao conteúdo da EF: “o que se deve saber" (conceitual), seria conhecer as transformações que passam a sociedade, os esportes, como executar de forma correta algumas técnicas corporais etc.; “o que se deve fazer" (procedimental), vivenciar os movimentos da dança, da ginástica, dos esportes, jogos e brincadeiras; e por fim o "como se deve fazer" (atitudinal), configura-se a valorização do patrimônio dos jogos, a questão do respeito e da não violência, a prática de atividades em grupo e de cooperação, habituar-se em praticar atividades físicas.

Voltando o olhar para o programa de habilidades que a EF da rede municipal de ensino visa desenvolver há continuidade nos anos finais, desde o $6^{\circ}$ ao $9^{\circ}$ ano em diversos aspectos, como cita o Referencial da Secretaria da Educação (2017): Conhecimento do corpo, associação da atividade física com os cuidados necessários à saúde, reflexões sobre perigos como sedentarismo, obesidade, anorexia, anabolizantes, etc.; Desenvolvimento das capacidades físicas; Conhecer e vivenciar jogos pré-desportivos, de cooperação e atividades 
adaptadas; Vivenciar diversas modalidades esportivas bem como o contexto histórico que as envolvem; Conhecer danças folclóricas, jogos e cultura africana, danças regionais e jogos não tradicionais; Entender esquemas táticos de jogo bem como as regras de modalidades esportivas.

Todas essas habilidades são importantes para o desenvolvimento do aluno nas aulas de EF e devem ser trabalhadas por meio das atividades escolhidas que compõe o plano do professor.

Os conteúdos aplicados na rede municipal nos anos finais são aplicados em trimestres, sendo o total de três trimestres ao longo do ano letivo. Os alunos possuem duas aulas de EF por semana com carga horária de 50 minutos, isto é, uma média de 8 aulas mensais. A seguir, será demonstrada no quadro 2, de maneira resumida, com os conteúdos de cada ano do ensino fundamental, conforme o Referencial da Secretaria da Educação (2017):

Quadro 2 - Conteúdos da Educação Física para anos finais do Ensino Fundamental na rede municipal de Ribeirão Preto.

\begin{tabular}{|c|c|c|}
\hline \multirow{4}{*}{$\begin{array}{c}\text { Conteúdos } \\
\text { para } 6^{\circ} \text { anos }\end{array}$} & $\begin{array}{l}\text { Corpo e } \\
\text { Saúde }\end{array}$ & $\begin{array}{l}\text { Conhecimento sobre o corpo; } \\
\text { Aquecimento e vestimenta adequada às aulas de Educação Física; } \\
\text { Aparelho locomotor: funções ósseas na atividade física e } \\
\text { movimento. } \\
\text { Mensuração massa peso/altura. }\end{array}$ \\
\hline & $\begin{array}{c}\text { Prática } \\
\text { Esportiva }\end{array}$ & $\begin{array}{l}\text { Jogos pré-desportivos: Cooperativos, Competitivos, Xadrez, } \\
\text { Olimpíadas Indígenas; } \\
\text { Basquetebol, Handebol, Voleibol e Futsal: histórico, conceito e } \\
\text { fundamentos; } \\
\text { Ginástica Artística; } \\
\text { Atletismo; } \\
\text { Esporte de Aventura: skate, rolimã, etc. }\end{array}$ \\
\hline & $\begin{array}{l}\text { Atividades } \\
\text { Rítmicas / } \\
\text { Ginástica }\end{array}$ & Danças folclóricas e regionais. \\
\hline & Lutas & $\begin{array}{l}\text { Contexto social das lutas; } \\
\text { Capoeira. }\end{array}$ \\
\hline $\begin{array}{c}\text { Conteúdos } \\
\text { para } 7^{\circ} \text { anos }\end{array}$ & $\begin{array}{l}\text { Corpo e } \\
\text { Saúde }\end{array}$ & $\begin{array}{l}\text { Alimentação e práticas saudáveis; } \\
\text { Capacidades físicas: força, flexibilidade, velocidade/agilidade e } \\
\text { resistência, equilíbrio; }\end{array}$ \\
\hline
\end{tabular}




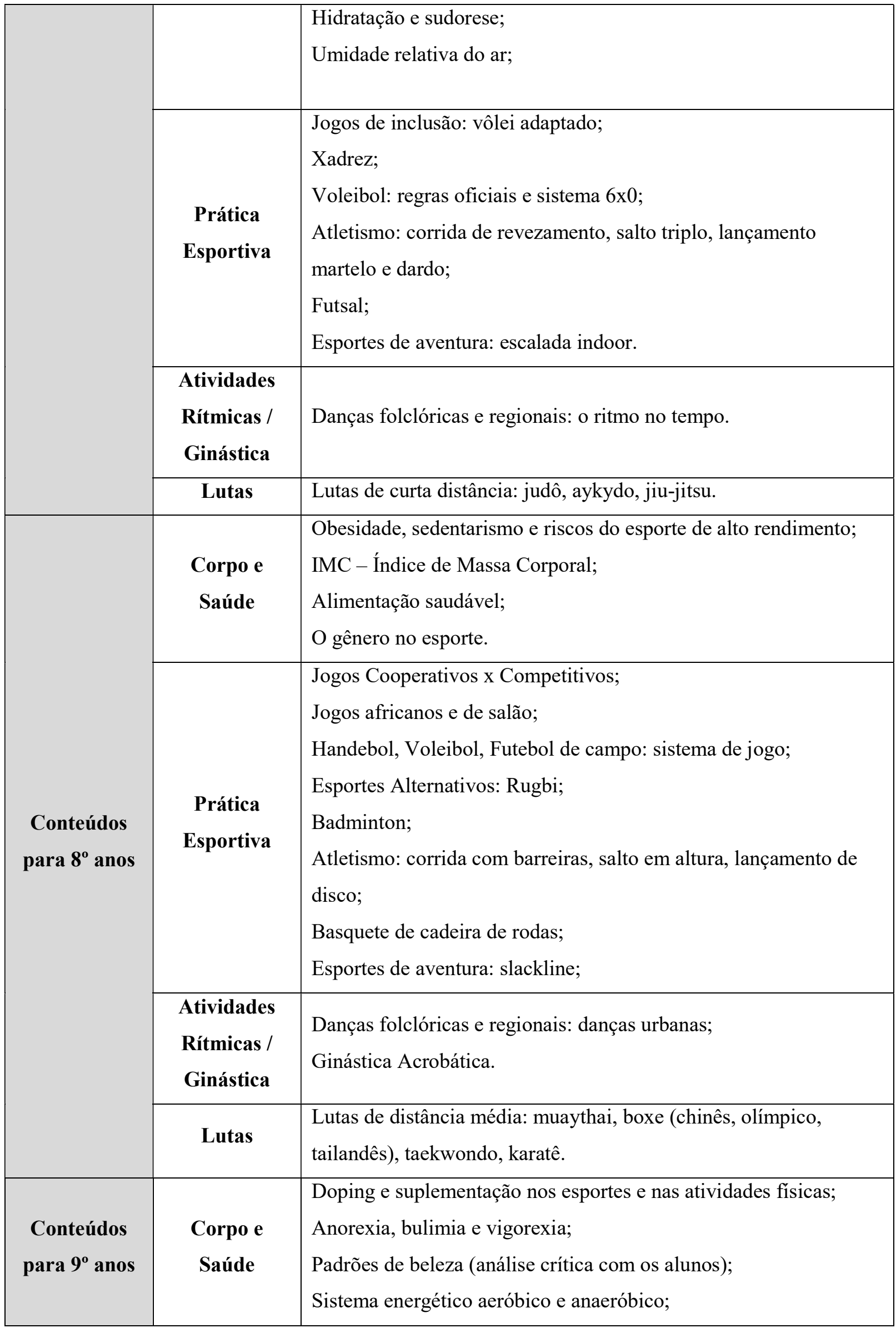




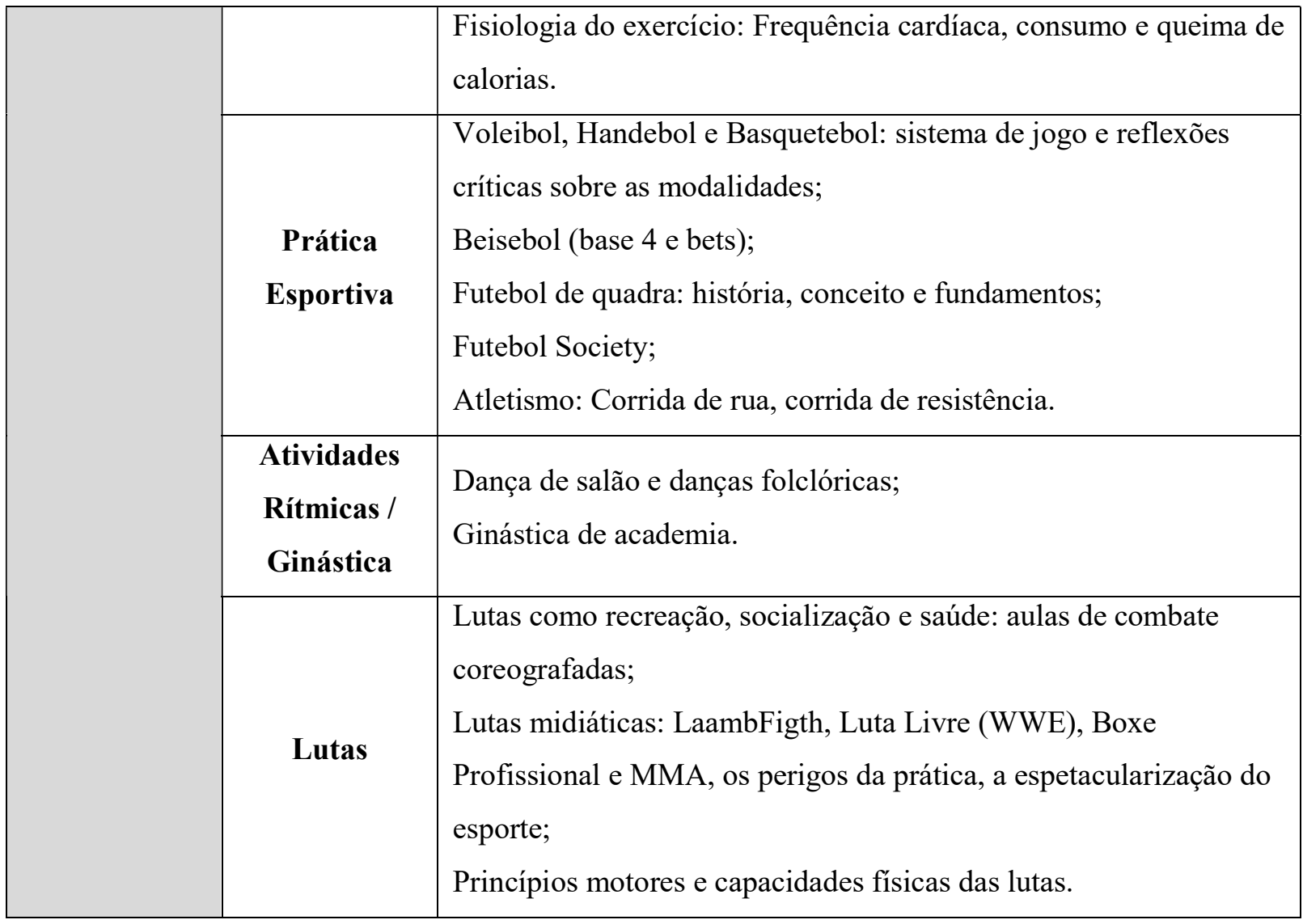

Fonte: Referencial Curricular Municipal (2017).

Conforme pode-se constatar, a EF é proposta na rede estadual de ensino do estado de São Paulo como na rede municipal de Ribeirão Preto, com objetivos similares para integrar o aluno na cultura corporal, conhecimento do corpo, modalidades esportivas e demais exercícios físicos. As propostas se diferem na quantidade de aulas oferecidas nos anos escolares (sendo duas aulas semanais na rede estadual e três na rede municipal) e também em alguns pontos na organização do conteúdo curricular. Essas três aulas são mantidas pela prefeitura de Ribeirão Preto assim como eram nos anos 80, porém, na Resolução SE $n^{\circ} 81$ de 16 de dezembro de 2011, Art. 2 o estado estabelece as duas aulas semanais para disciplinas de Arte e EF (SÃO PAULO, 2011). Existe um projeto de lei $n^{\circ}$ 249/2012 que estabelece carga horária mínima para a EF de duas horas semanais. Como ainda não foi aprovado pela câmara dos deputados, não se sabe como esse tempo de aula será organizado.

É evidente que sobre o conteúdo existe ainda a organização da escola, o planejamento do professor e o ambiente que determinados alunos estão inseridos culturalmente. Portanto, é preciso destacar que ambos os conteúdos e independente da estrutura, as duas redes preconizam em seus discursos e documentos atingir os objetivos da disciplina em seus 
documentos oficiais de propostas, visando que o aluno aproveite ao máximo de suas aulas e tenha oportunidade de experimentar o amplo conteúdo que a EF tem a oferecer.

A rede estadual de ensino propõe o uso dos "cadernos do professor e do aluno", não só para a EF, mas para todas as disciplinas. Nos cadernos contém o conteúdo a ser trabalhado por cada ano do ensino, porém, a maior crítica que se faz é a falta de sugestão de como trabalhar tais conteúdos, sem progressões pedagógicas e geralmente escritos por pessoas que não atuam/atuaram na prática. Lima et al. (2015) ao estudarem a Ginástica Artística (GA) proposta nos cadernos pela Educação do Estado de São Paulo percebem a proposta apenas como um ponto de partida, pois existem lacunas como: poucas orientações para organizar a aula, falta de sequência pedagógica para os movimentos da GA, falta de aprofundamento do conhecimento sobre o ambiente, segurança e eventual ajuda manual. Assim, os autores frisam que os cadernos são importantes fontes de consultas aos profissionais e fornecem a visualização da GA no contexto escolar, porém, não orientam adequadamente os professores, ou seja, ainda é preciso um conhecimento mais amplo.

Com relação à rede municipal de Ribeirão Preto, não existe material como os "cadernos" do Estado, ela é baseada em seus referenciais, os quais seguem (como já destacado em sessão anterior) as dimensões: conceitual, procedimental e atitudinal (ZABALA, 1998) e não há uma abordagem pedagógica definida a se seguir nos referenciais. Contudo, o que se observa a partir dos conteúdos e habilidades de cada segmento (ano e trimestre) é a presença de abordagens como: crítico-superadora, ao refletir sobre os esportes e voltar a prática do movimento à cultura corporal; a crítico-emacipatória, na qual observamos atividades que visam conscientizar para superação de injustiças sociais, tais como conhecer jogos cooperativos, atividades adaptadas bem como jogos e brincadeiras voltados à emancipação do movimento e diversão; e também se observa, e muito, a abordagem da saúde renovada, quando se propõe conteúdos voltados à conscientização para a prevenção de doenças posturais, distúrbios alimentares, sedentarismos e prática regular de exercícios.

Tendo em vista que o aluno é o principal agente da EF escolar, como citado algumas sessões anteriores, o próximo item será para conhecer melhor sobre a criança e o adolescente, bem como a faixa etária escolar que envolve o ensino fundamental.

\subsection{A Criança e o Adolescente na fase escolar}


Segundo o Estatuto da Criança e do Adolescente (ECA), esse público é definido por meio da seguinte faixa etária: até os 12 anos incompletos considera-se criança, e dos 12 aos 18 o adolescente (BRASIL, 1990). A Organização Mundial de Saúde (OMS) (1965) define uma abrangência maior de idade à adolescência, atribuindo dos 10 aos 20 anos e antes desse período então a fase da infância. Salles (2005) cita que esses conceitos de criança e adolescente surgiram associados à sociedade industrial, vinculada às leis do trabalho, para separar assim este público dos adultos, do mundo de responsabilidades trabalhistas e configurá-los como dependentes dos pais. Contudo, o conceito de adolescência surgiu com a escolarização para separar o adulto do sujeito em formação.

A adolescência, que caracteriza os agentes desse estudo, inicia-se com as mudanças corporais da puberdade, o aumento de hormônios, a alteração de forma física, o ganho de força, altura e a sexualidade, além de mudanças de comportamentos psicossociais. Ela se encerra com a inserção social, profisssional e econômica do indivíduo na vida adulta (SCHOEN-FERREIRA; AZNAR-FARIAS, 2010). Assim, é a fase de transição gradativa da criança para a vida adulta com adaptações corporais e psicológicas para novas responsabilidades e compromissos que se seguirão.

Exímia de responsabilidades como possuem os adultos, a criança é inserida no ambiente escolar para aprendizado e formação. O art. 53 do ECA (1990) garante que: "A criança e o adolescente têm direito à educação, visando ao pleno desenvolvimento de sua pessoa, preparo para o exercício da cidadania e qualificação para o trabalho", bem como a garantia de acesso à escola.

Com a alteração do Ensino Fundamental para nove anos, a criança passou a iniciar sua formação básica aos seis anos de idade, o que antes pertencia à Educação Infantil, e encerra assim o ciclo por volta dos 14 ou 15 anos (BRASIL, 2006). Assim, o segundo ciclo do Ensino Fundamental, público trabalhado neste artigo, contempla do $5^{\circ}$ ao $9^{\circ}$ ano, abrangendo a faixa etária dos 11 aos 14-15 (aproximadamente) com quatro anos de duração (BRASIL, 2005).

A proposta em ampliar o ensino de oito para nove anos visa garantir maior convívio da criança no ambiente escolar e mais oportunidades educativas, em especial àquelas desfavorecidas socioeconomicamente e excluídas do sistema educacional (ARELARO; JACOMINI; KLEIN, 2011), considerando uma etapa que o desenvolvimento de habilidades cognitivas, afetivas e sociais é fundamental.

Para as aulas de EF, segundo os PCNs (1997) é de responsabilidade dos primeiros anos a iniciação do repertório motor, atividades lúdicas para conhecimento do corpo, movimentos e da cultura corporal, enquanto aos anos finais cabe o aperfeiçoamento de movimentos 
corporais, das técnicas já aprendidas, aprofundamento nas modalidades esportivas e um pensamento crítico e reflexivo sobre a atividade física no seu cotidiano.

Nessa perspectiva, o aluno em seu ambiente de estudo e exposto às aulas de EF precisa de estímulo, incentivo e significado para sua prática atingir os objetivos educacionais e promover o seu desenvolvimento como cidadão ao longo dos anos. No entanto, e conforme elucida a justificativa desta pesquisa, a EF escolar encontra-se em alguns contextos escolares em que muitos não se sentem motivados a praticá-la, e após entender um pouco sobre o público que usufrui dessa disciplina, a próxima sessão aprofundará sobre a motivação.

\subsection{Motivação}

A palavra motivação está associada ao vocábulo motivo, o qual se caracteriza por uma força interior, um impulso, que faz a pessoa agir ou fazer algo de uma forma, sendo ela uma das formas pelas quais se explica o comportamento dos indivíduos. "Ser motivado significa ser movido para fazer alguma coisa" (RYAN; DECI, 2000, p.54). Assim, um indivíduo que não sente vontade ou ímpeto de agir é considerado como alguém não motivado, enquanto aquele indivíduo energizado ou ativado para algo é considerado motivado (RYAN; DECI, 2000).

Todorov e Moreira (2005) definem que a motivação é um conjunto de mecanismos biológicos e psicológicos que desencadeiam uma ação e norteiam fatores como orientação, intensidade e persistência à meta pretendida ou ao afastamento dela: quanto mais motivada a pessoa estiver, mais persistente e maior será a atividade. "Em toda e qualquer ação desempenhada pelo ser humano, a motivação está presente como um dos fatores que pode determinar êxito ou fracasso na execução de tarefas" (PEREIRA, 2006, p. 46). É um conceito que está ligado ao comportamento da pessoa, ou seja, um impulso ou intencionalidade em realizar determinada tarefa ou ação (MAGILL, 1984). Seria ela "o processo que leva as pessoas a uma ação ou à inércia em diversas situações, sendo ainda o exame das razões pelas quais se escolhe fazer algo" (TRESCA; DE ROSE JR., 2000, p. 9).

Existem três variáveis que os conceitos de motivação enfatizam e Witter e Lomonaco (1984) nos apontam elas: aspectos ambientais; forças internas como vontade, desejos, emoções, etc.; objeto ou alvo que atrai ou repele o organismo. Sendo assim, ao perceber inquietações e necessidades no meio em que vive, o indivíduo sente desejos e impulsos para determinada ação e por meio dessa irá obter prazer ou repelir algo indesejado. 
É importante frisar também que Weinberg e Gould (2001) definem a motivação como sendo a busca ou proximidade de uma pessoa em determinada meta e a intensidade ou esforço que ele aplica para atingi-la. A motivação pode estar centrada no indivíduo, na situação ou na interação entre ambos.

Voltando a visão para o âmbito escolar, em que se caracteriza o processo de ensinoaprendizagem, Witter e Lomonaco (1984) ressalta ligação direta da motivação, sendo ela o fio condutor para explorar o ambiente e pelo interesse do indivíduo na atividade há maior a possibilidade de construir o próprio conhecimento. Quanto mais se explora o ambiente, maior a construção do conhecimento, ou seja, pela curiosidade é que a pessoa aprende (KOBAL, 1996).

A motivação é fator importante no processo ensino-aprendizagem para impulsionar estudos, trabalhos e outras atividades, e um aluno desmotivado não possui a mesma dedicação em relação ao motivado (FOLLE; TEIXEIRA, 2012). Isso confirma a importância da motivação no espaço educacional e como ela norteia o sucesso das atividades desenvolvidas. A motivação tem relação de reciprocidade com o processo de aprendizagem, pois o educando pode chegar ao aprendizado por estar motivado, ou pode atingir a motivação pelo fato de querer mais conhecimentos (MAGILL, 1984).

É importante afirmar também que a motivação serve como fio condutor de várias circunstâncias na aprendizagem, sendo que o interesse do indivíduo pela atividade faz com que ele construa seu próprio conhecimento e, além disso, os problemas relacionados à motivação atingem todas as faixas etárias de alunos, professores, coordenadores e demais membros da gestão escolar (KOBAL, 1996).

A motivação sendo algo que impulsiona as ações do ser humano pode atrai-lo ou não em determinada atividade. Ela está ligada diretamente aos motivos, isto é, aos interesses que norteiam o indivíduo em uma ação ou atividade que pratica. As pessoas possuem orientações diferentes de motivação (RYAN; DECI, 2000), e essa orientação está ligada aos objetivos e atitudes das pessoas. Por exemplo, um aluno pode se sentir motivado em fazer o dever de casa pelo interesse e curiosidade em aprender ou apenas para agradar seus pais e obter a aprovação do professor (cumprir obrigações).

Uma das teorias da motivação, que norteia discussões na área educacional e será abordada neste estudo, é a da autodeterminação, a qual apresenta duas orientações: a Intrínseca e a Extrínseca. Ryan e Deci (2000) definem que a intrínseca envolve comportamentos exploratórios, ligados à curiosidade, realização própria e diversão, são comportamentos espontâneos que não anseiam recompensa instrumental, mas são praticados 
em razão das experiências positivas associadas à extensão das capacidades. Enquanto a motivação extrínseca está claramente ligada ao recebimento de recompensas, gratificações com valor a parte da atividade. A busca um resultado separável à ação é o mais presente nas atividades do homem adulto, possuindo uma autonomia relativa.

Kobal (1996) utiliza esses conceitos dos autores e reafirma que quem está motivado intrinsicamente possui atração pela atividade de forma a despertar o interesse em executá-la novamente ou mesmo uma atividade semelhante, o indivíduo se sente autodeterminado e competente, sua vontade é uma causa interna, sendo assim a recompensa é inerente à atividade. O indivíduo motivado extrinsecamente possui suas razões de prática externa à atividade, ou seja, espera benefício material ou algo que agrade caso a tarefa seja cumprida com sucesso (KOBAL, 1996). Ela se faz mais presente inclusive entre os alunos quando participam da atividade ou realizam o que é proposto pela obrigação de notas ou aprovação na disciplina.

Um exemplo a se destacar inclusive nas aulas de EF é que um aluno que pratica as aulas de voleibol sente-se alegre e busca progredir em seus fundamentos técnicos por curiosidade e benefícios que não sejam externos ao jogo, é um aluno intrinsicamente motivado. Porém, aquele que pratica a mesma aula, não pelo prazer de participar ou aprender o esporte, mas para se sobressair, outros retornos materiais, como nota ou até mesmo pressão familiar, é um indivíduo motivado extrinsecamente.

Segundo Rocha (2009), recompensas externas podem prejudicar a motivação intrínseca, a não ser que essa também seja elevada e, estando motivado intrinsecamente, o indivíduo em atividades relacionadas à EF têm se mostrado mais esforçado, perseverante e com maior grau de satisfação.

Em um estudo com docentes de EF realizado por Prandina e Santos (2016), afirmam em seus resultados que as crianças dos anos iniciais possuem muito mais motivação nas aulas, preferindo jogos e brincadeiras do que às do ensino médio, que na maioria das vezes praticam a atividade apenas pelo conceito da nota. Assim, temos que as crianças, em alguns casos, estão mais motivadas intrinsecamente para a EF. Contudo, após a primeira infância, a liberdade de ser intrinsecamente motivado torna-se cada vez mais reduzida pelas demandas sociais e os papéis de responsabilidades que passam a assumir em suas vidas, tornam-se atividades pouco interessantes. Nas escolas, por exemplo, a motivação intrínseca parece apresentar-se mais fraca ao avançar dos anos letivos (RYAN; DECI, 2000).

Conforme este conceito, Kobal (1996) revela em estudos que a motivação intrínseca se mostra mais favorável à aprendizagem, pois o conhecimento obtido fixar-se-á e se manterá 
constante, enquanto na extrínseca ele se deteriora, pois não é algo prioritário quando atingida a necessidade ou recompensa do seu praticante. Devemos canalizar a motivação ao aluno não só em motivos novos, mas também naqueles existentes, isto é, proporcionar significância sobre o que ele traz de desafiador e que isso passe a ser algo atraente e satisfatório para se atingir.

No que envolve o indivíduo em questões de competição ou rendimento, os indivíduos que estão altamente motivados respondem mais rápido e aprendem com mais facilidade em relação àqueles com baixo grau de motivação. Contudo, esse êxito depende de aplicações e tarefas que não sejam monótonas, rotineiras e sem desafios (PEREIRA, 2006). Com essa colocação da autora e ao analisar as abordagens intrínsecas e extrínsecas, o indivíduo motivado intrinsecamente encontra prazer e satisfação no que realiza, mesmo em caso de competições, em que haja pressão por metas e resultados, pode para ele significar desafio satisfatório e atraente, por exemplo.

Rocha (2009) confirma que pessoas podem participar de competições esportivas por motivos intrínsecos. São indivíduos motivados a se tornarem competentes, aprenderem novas competências, apreciam competições ou excitações e com isso se divertem e aprendem ao máximo que forem capazes. A ideia de competição pode em alguns casos trazer a hipótese de aspectos motivacionais apenas extrínsecos, pois envolvem recompensas e motivos que estejam externos à atividade, porém, existem pessoas que têm na competição o prazer e a alegria na prática da própria atividade.

Além das abordagens intrínsecas e extrínsecas da motivação, muitas são as teorias que visam explicar os conceitos e a reação dos indivíduos. Kobal (1996) destaca diversas teorias da motivação e seus respectivos autores, e explica as origens e formas de comportamento, as quais se destacam algumas: a teoria da vontade, dos instintos, do impulso, da intensidade do estímulo, do prazer, da curiosidade, de campo, da autonomia funcional, teoria hierárquica da motivação humana e a cognitiva, a qual esta última se baseou em seu estudo. $O$ autor ainda ressalta que a motivação, seja por impulso ou por incentivo, é necessária para o desempenho do indivíduo em qualquer atividade.

Rocha (2009) também elucida teorias da motivação que estão ligadas aos contextos educativos e esportivos, tais como: teoria da autodeterminação de Deci e Ryan (1981), teoria da motivação de realização proposta por Atkinson e McClelland (1953), teoria da atribuição de Weiner (1985), teoria das metas de realização defendida por Nicholls (1984) e teoria da competência, caraterizada por sua importância na área esportiva (WEINBERG; GOULD, 2001). A seguir, essas teorias serão explicadas. 


\subsubsection{Teorias da Motivação}

A teoria da autodeterminação (abordada por este trabalho) se baseia na necessidade de autonomia, competência e relação social da pessoa, a qual é capaz de mudar o contexto que se insere influenciada pelas condições biológicas e socioculturais (RYAN; DECI, 2000b). Autonomia refere-se ao fato de ser fonte do próprio comportamento e alcançar a concordância entre as atividades e o próprio senso. Competência refere-se à necessidade de ter um efeito sobre o meio ambiente e alcançar resultados desejados.

A relação social é a vontade de sentir-se conectado aos outros, estar integrado no meio social (TAYLOR; NTOUMANIS, 2007). Rocha (2009) confirma essas necessidades na qual a pessoa tem força para determinar seu próprio comportamento por meio da autonomia, a competência se relaciona à intenção de controlar os resultados e a relação com os outros seria em experimentar a satisfação com o mundo social.

Portanto, nessa teoria a transformação de comportamentos regulados externamente em comportamentos que são valorizados e possuem significados para esses indivíduos, faz com que tende a prosseguir uma atividade por motivos autodeterminados e sentirem-se competentes (TAYLOR; NTOUMANIS, 2007).

A motivação para realização se pauta na interação que considera como importantes para o comportamento, fatores pessoais e situações que o indivíduo vivencia. Cinco componentes estão ligados a essa teoria: personalidade e motivos; situações; tendências resultantes; emoções; e comportamentos relacionados à realização (WEINBERG; GOULD, 2001). Nessa teoria, McClelland apud Rocha (2009) destaca a necessidade que a pessoa adquire ao longo da experiência de vida e o desejo de atingir esses objetivos de forma eficiente. $\mathrm{O}$ autor ainda ressalta que quando a necessidade de realização é maior do que o medo de fracassar, a resultante será tentar realizar e assumir os riscos. Contudo, quando o inverso acontece, e há maior necessidade em evitar o fracasso, o risco se faz ameaçador e a situação será evitada. Nessa perspectiva, é importante considerar o contexto social e cultural que a pessoa se encontra, principalmente, no que diz respeito a estudantes, em que a instituição ou até mesmo as aulas de EF que vivem, transcendem culturas, podendo eles ter mais elevação positiva ou negativa em sua motivação de realização (PEREZ et al., 2004).

A teoria da atribuição tenta explicar os sucessos e os fracassos (WEINBERG; GOULD, 2001), isto é, Weiner (1985) explica que para toda ação da pessoa haverá uma 
causalidade de sucesso ou fracasso que, por sua vez, resultará em sentimentos e emoções diversas. $\mathrm{O}$ fato de como o indivíduo percebe o seu sucesso ou fracasso é fator decisivo para realizar ou não uma tarefa, bem como o tempo de perseverança em alcançar tal objetivo. Quando se percebe no aluno o fracasso atribuído à falta de capacidade há um sentimento incontrolável de vergonha e o desempenho tende a declinar. Por outro lado, se o fracasso se der por falta de esforço percebe-se um sentimento de culpa, é algo controlável e o desempenho se eleva (ROCHA, 2009).

A teoria das metas de Weinberg e Gould (2001) ressalta ser o alcance dos objetivos e anseios traçados e como se percebem as capacidades para se atingi-los. Seria a demonstração de resultados. A capacidade se pauta em dois contextos: na questão da tarefa, isto é, como o sujeito se julga habilidoso e percebe seu domínio sobre a realização da mesma, e também na questão do ego, na qual ele compara sua capacidade de resolução de uma tarefa aos demais indivíduos (NICHOLLS, 1984).

E, por fim, a motivação para competência está muito relacionada ao preparo de atletas, nos quais há desafios e excitações em competições e superação de seus objetivos, que melhora a cada dia suas habilidades e aprende cada vez mais (WEINBERG; GOULD, 2001).

Com toda apresentação sobre abordagens e teorias que envolvem a motivação, pode-se perceber que muitas se encaixam em diversos momentos e atividades do nosso cotidiano, e assim na EF escolar não é diferente, pois muitas dessas teorias são observadas nos comportamentos dos alunos.

Atualmente, em nosso ambiente escolar, inclusive nas aulas de EF, observa-se práticas aplicadas com base em motivações extrínsecas, contudo, se o ideal para o aluno é a motivação intrínseca, os profissionais têm utilizado estratégias adequadas e que considerem os diferentes contextos (sociais e culturais) dos alunos? Na maioria das vezes, a extrínseca se faz necessária para fomentar a participação dos estudantes, e isso faz com que tenha sua importância, porém, é papel do professor não permitir que apenas essa motivação prevaleça, mas a partir dela, desperte intrinsicamente o prazer nos alunos nas diversas atividades.

\subsubsection{A motivação e a educação física escolar}

A motivação é essencial para as aulas de EF devido à compreensão do desempenho e da aprendizagem, tem importante papel na iniciação, na manutenção e na intensidade do 
comportamento e não há como ser imposta, devendo haver interesse pela qualidade, caso contrário, os alunos não realizam a atividade satisfatoriamente (SANTOS; DUQUE, 2010).

Nas aulas de EF é muito mais fácil identificar a falta de motivação, por se tratar de uma disciplina que pedagogicamente possui atividades de prática corporal, isto é, o aluno desinteressado dificilmente passaria despercebido (NETO et al., 2010).

"Os alunos que realmente gostam das aulas chegam extremamente motivados, com as equipes escolhidas por eles mesmos para jogar o desporto preferido. Por outro lado, existem aqueles que nem participam das aulas, sempre inventando desculpas para o professor" (ROCHA, 2009, p. 92).

É extremamente comum o professor encontrar alunos dispostos a praticar todo tipo de atividade, alunos que apreciem atividades cooperativas e coletivas e não gostem de práticas individuais, outros que preferem as individuais, aqueles alunos também que possuem interesse na atividade, mas insegurança ao praticá-las e, por fim, os que não apreciam prática alguma (KOBAL, 1996).

Tem-se, portanto, um ambiente em que é preciso trabalhar fatores motivacionais com interesses extremamente diversificados, principalmente, tratando-se de adolescentes que estão em uma faixa etária de muitas transformações. Marzinek (2006) destaca que os professores têm trabalhado muito pouco a questão do lúdico, por exemplo, com o jogo que possui caráter recreativo e permite aos alunos vivenciarem atividades que os motivem intrinsicamente (prazer, vontade e determinação). “O professor de Educação Física deve estar sempre atento aos fatos e objetos que os alunos conhecem na sua vida diária, seus interesses e curiosidade em ampliar seus conhecimentos" (SILVA, 2010, p. 23).

“Cabe, portanto ao professor, usando de sensibilidade aguçada, perceber qual é a vivência corporal que o aluno traz para a escola, que influências ele já sofreu (e sofre) na sua cultura corporal” (KOBAL, 1996, p. 95). Assim, trabalhar o nível motivacional dessa diversidade de alunos por meio de conteúdos que atinjam a todos os gostos e utilizar atividades lúdicas como aliada nesse processo. Vejamos, a seguir, alguns fatores de forma mais detalhada.

Diante de uma diversidade de alunos e preferências a EF escolar tem mostrado um elevado número de alunos desmotivados e sem interesse em participar das aulas. Santos e Duque (2010) ressaltam a falta de interesse dos alunos pelas aulas de EF devido às experiências anteriores não prazerosas; os autores citam ainda Almeida (2007) que destaca os conteúdos e a metodologia como fator relevante ao afastamento dos alunos, nos quais apenas os esportes são privilegiados e aplicados de maneira inadequada e, muitas vezes, sem 
planejamento; e Paula e Fylyk (2009) que pontuam a faixa etária da adolescência que possui fatores fisiológicos e psicológicos, como vergonha do corpo, mudanças hormonais que interferem nos motivos de interesse dos alunos. Esses dados contribuem para elucidar a ineficiência em manter a motivação dos alunos na EF escolar.

Vale ressaltar outro fator que está ligado à motivação dos alunos para as aulas de EF, que é o papel e a participação do professor. "O tratamento dos alunos de maneira desigual, concedendo maior atenção e privilégios a uns, por exemplo, aos mais habilidosos, em detrimento de outros, conduz a uma atitude negativa perante a Educação Física" (KOBAL, 1996, p.42). O autor afirma ainda que, o constrangimento do aluno por ser o último escolhido na atividade, ser nivelado como ruim por conta de suas habilidades, ser rapidamente eliminado em alguns jogos, são aspectos desfavoráveis à motivação intrínseca que o professor poderia causar. Prova disso, Darido (2004) mostra que apenas os alunos mais habilidosos estão engajados nas atividades propostas e são os mais valorizados pelos professores, afastando assim os que mais precisam de estímulo para praticar atividade física.

Em vista disso, é importante que o professor adote uma postura para motivar os menos habilidosos, que mostre a eles a importância em desenvolver a atividade e que são absolutamente capazes de realizá-la no seu tempo e limitação. O fato de elogiar, incentivar e encorajar são atitudes que, segundo Samulski (2002), o professor deve utilizar como estratégia de comunicação com os alunos, abordar os problemas de forma positiva, proporcionar vivências de autonomia, responsabilidade, cooperação e elevar a autoestima desses agentes. Evitar pensamentos negativos e atitudes não desejadas, mas é válido que haja para motivação formas positivas, força de vontade e entusiasmo, enfim, formas adequadas ao comportamento.

Darido (2004) destaca algumas características que contribuem para melhorar sua aula com automotivação, experiências positivas, alegria dos adolescentes e estado de fluxo durante as atividades, são elas: momentos de sucesso e prazer durante a atividade, desenvolvimento da amizade e trabalho em grupo, variação e criatividade na aplicação dos exercícios, atividades desafiadoras, manterem boa relação professora/aluno, evitar sempre atividades competitivas.

É importante que a autodeterminação seja promovida nas aulas de EF, com um estilo de aula voltado à autonomia dos alunos, fornecer justificativa para as atividades praticadas, melhorar o sentimento de vontade e a percepção da causa e importância de sua prática na aula. É importante que o professor se utilize de estratégias de envolvimento não só da aula, mas também para com o aluno, conhecendo seus antecedentes familiares e o contexto em que vive. A percepção do professor para com o aluno pode influenciar na motivação do mesmo, é 
preciso promover a autonomia, a competência e um bom relacionamento (TAYLOR; NTOUMANIS, 2007).

Para Santos e Duque (2010) a motivação é um fator importante para a participação dos alunos na EF, e afirmam que a desmotivação dos alunos ocorre em virtude de conteúdos metódicos que são aplicados em aula (SANTOS; DUQUE, 2010, p.7). Pode-se afirmar, portanto, que o conteúdo da aula é o cartão de visita que se apresenta ao aluno, no qual ele analisa os benefícios e interesses em praticar o que lhe é proposto. Por exemplo, em uma aula que se trabalhe um jogo pré-desportivo para iniciação do basquetebol, caso o professor não atribua significado e apresente motivos e porquês dessa prática, aquele aluno desinteressado em atividade física não se sentirá motivado em participar.

Durante as aulas de EF é comum que predomine a aplicação de atividades esportivas ligadas à competição. Nessas atividades é evidente que participarão os alunos mais habilidosos e familiarizados com os esportes, porém, os demais ficam à margem, sem praticar ou então, nutrem a desmotivação pela disciplina. Prova disso, Kobal (1996) destaca que os aspectos competitivos enfraquecem a motivação intrínseca, porém, os cooperativos ajudam na sua elevação, reduz a ansiedade, contribui na socialização e favorece o trabalho coletivo. "O ideal seria existir um espírito de cooperação, o que consiste num dos objetivos primordiais da Educação Física Escolar" (KOBAL, 1996, p. 64). É importante que o professor saiba ponderar em seu plano de aula o equilíbrio entre as atividades competitivas, cooperativas, dentre outras, que proporcionem significado e atribuam a importância de suas práticas para o cotidiano dos alunos, e assim, trabalhem aspectos intrínsecos da motivação.

Em relação à motivação extrínseca que muito se percebe nos conteúdos da EF, Kobal (1996, p.65) aponta que:

"É provável que recompensas externas sejam eficazes para a aquisição de alguns comportamentos desejados pelo sistema escolar, mas talvez estes comportamentos não se tomem autodeterminados, o que reduz muito a probabilidade de serem eles internalizados".

Os autores Stavisky e Cruz (2008) apud Santos e Duque (2010) frisam que conteúdos repetitivos e a ausência de boa interação entre colegas e mesmo com os professores geram um fator prejudicial na motivação e contribui para o afastamento dos alunos das aulas de EF.

Neto et al. (2010) reforçam que as atividades se têm mostrado como fatores que desencadeiam o afastamento dos alunos por se mostrarem repetitivos e se restringirem muito à execução de técnicas esportivas. O autor ainda cita Barbosa (2007), que frisa a maneira inapropriada de aplicação do currículo e que a prática não deve ser descontextualizada, isto é, 
“é preciso que sua intervenção se realize com reflexões, mas sem perder suas características procedimentais" (NETO et al.,2010, p.8).

Vale ressaltar ainda que além dos conteúdos, o professor também possui seu fator motivacional que contribui para o sucesso das aulas. Atualmente, os professores enfrentam dificuldades com a disciplina dos alunos, baixa remuneração, falta de formação continuada, estrutura de trabalho precária, materiais escassos, dentre outros. Juntamente com isso, temos a questão da estrutura oferecida para as aulas, que envolve não só a motivação do professor (como seu ambiente de trabalho), mas principalmente do aluno (agente principal do ensino), locais extremamente desapropriados para a execução das aulas, e ainda com precariedade de materiais (quando não ausência dos mesmos).

Contudo, é preciso trabalhar o fator motivacional em diversos aspectos, porém, como mostra Weigand (2001) que as expectativas, valores e crenças do esporte e da EF devem ser elucidados e internalizados pelos participantes para que eles moldem suas próprias e, assim, favoreçam o clima motivacional. Reitera-se, portanto, a importância do professor de EF para a orientação de tarefas percebidas pelos alunos com satisfação, alegria e intencionalidade que promovam o aumento da motivação intrínseca.

Diante do cenário em que os conteúdos são repetitivos, sem significância para o aluno e isso o afasta da prática da EF, o professor como ressalta Marzinek (2006) é o agente em que a criança deposita toda sua esperança e expectativa, nessa relação professor-aluno há desejo de conhecimento, de serem notados e percebidos individualmente. O professor deve estar incentivando seu aluno a sempre praticar atividade independente da faixa etária. Contudo, quando a motivação do professor se encontra baixa, ele não se interessa em passar novos conteúdos e frisa apenas o ensino de esportes, o que reflete por fim na motivação de seus educandos.

Diante de tal situação, ao analisar a motivação nas aulas de EF em algumas faixas etárias percebe-se que a partir dos 14 aos 16 anos de idade os alunos são mais reservados e apenas metade deles desejam a EF obrigatória. O mesmo se configura aos alunos com 17 anos que buscam por outras atividades físicas (muitas vezes externas), por acompanhamentos psicológicos e muitos preferem a EF como disciplina opcional (MARZINEK, 2006).

Portanto, nas aulas de EF o tipo de motivação que leva os indivíduos a realizar mais esforço, apresentar maior perseverança e obter um grau de satisfação mais elevada é a motivação intrínseca. Confirmando esse fato, alunos relacionam à figura do professor o fato de possuírem uma ótima aula, aprender a praticar esportes, vivenciar atividades diversificadas, desfrutar de uma aula saudável e divertida, prazer em se movimentar, fazer 
novas amizades e assim, a maioria aprecia a aula motivados intrinsicamente (TRESCA; DE ROSE JR, 2000).

Sendo o adolescente um indivíduo em constante transformações físicas, sociais e psicológicas, "é importante que a atividade física nas aulas de Educação Física seja motivadora e espontânea, trazendo benefícios para a saúde de quem a pratica" (MARZINEK, 2006, p. 45).

Devido a relevância da relação entre saúde e atividade física, a prática bem orientada de exercícios físicos traz inúmeros benefícios à população, assim é preciso que a EF crie nos alunos o gosto por essa prática, visando um estilo de vida saudável (FERREIRA, 2001). Os próprios PCNs citam a preocupação em promover a saúde e a qualidade de vida a partir da Educação Física e os cuidados e conhecimento sobre o corpo é muito abordado nas propostas de ensino estadual e municipal. Portanto, e até mesmo por este estudo trazer a conscientização da promoção da saúde (pela EF) em seus objetivos específicos, a próxima sessão elucida a saúde no âmbito educacional bem como na EF escolar.

\subsection{Promoção da Saúde na Educação}

Saúde pode ser definida pela Organização Mundial de Saúde (OMS) como o "estado de completo bem-estar físico, mental e social e não apenas a ausência de doenças" (BRASIL, PCNs SAÚDE, 1997, p. 65). Assim, nenhum indivíduo é totalmente saudável ou totalmente doente, isto é, não há estabilidade na saúde tida como "saúde ótima", ao longo da existência, todos terão situações saudáveis ou não de acordo com suas potencialidades, condições de vida e interações com elas (BRASIL, PCNs SAÚDE, 1997). Guedes (1999) confirma essa não estabilidade de um estado saudável e afirma, ele deve ser construído e adquirido ao longo da vida de forma individual, fazendo da saúde algo educável e parte do contexto didáticopedagógico. Ressalta ainda que, a educação para a saúde é realizada por cada um mediante as exigências do meio em que vive pelos hábitos alimentares, situações de estresse, atividade física, lazer, dentre outros, sendo assim, não basta não estar doente para ser considerado saudável.

Saúde e Educação possuem uma interação evidente quando se trata da qualidade de vida das pessoas, sejam em ambientes como a escola ou em serviços de saúde. Para as escolas, nas atuais condições, as práticas pedagógicas para esta interação têm se mostrado desafiadoras (CARVALHO, 2015). Em vista disso, a escola torna-se um dos locais que visam à promoção 
da saúde de crianças e adolescentes. É importante destacar também que os artigos de número 4 e 7 do ECA garantem prioridade de políticas públicas às crianças e adolescentes e nelas estão presentes a questão da saúde desses indivíduos (BRASIL, 1990):

Art. $4^{0} \S$ único, item C: "preferência na formulação e na execução das políticas sociais públicas";

Art. $7^{\mathbf{0}}$ : "A criança e o adolescente têm direito a proteção à vida e à saúde, mediante a efetivação de políticas sociais públicas que permitam o nascimento e o desenvolvimento sadio e harmonioso, em condições dignas de existência".

Ações educativas para a saúde na escola estão presentes desde os tempos remotos da Primeira República, porém, com características voltadas aos hábitos saudáveis, práticas higienistas, desenvolvimento de um corpo sadio e produtivo, controle e disciplina. As práticas eram pedagogicamente individualistas e sem considerar o contexto e as condições de vida da criança (CARVALHO, 2015).

Atualmente, a saúde na escola recebe uma nova temática baseada na intersetorialidade, na qual Carvalho (2015) afirma ser uma intercessão entre o conhecimento dos profissionais de saúde, os de educação e a experiência de vida dos sujeitos envolvidos, analisando as condições de implementação dos hábitos de vida para oferecê-las como opções de melhoria da qualidade de vida.

A escola estando dentro da intersetorialidade torna-se um dos pilares para reduzir as situações de vulnerabilidade, respeitando as diferenças de locais e contextos culturais de crianças e jovens. O ambiente escolar é o local em que o aluno passa grande parte do seu dia, onde possui uma vasta interação social (com amigos e professores), onde exerce atividades de aprendizagem, enfim um local propício a se propagar e incentivar formas de prevenção de doenças, práticas saudáveis e melhoria da qualidade de vida. É preciso acentuar que nesse ambiente escolar Costa, Silva e Diniz (2008) afirmam que, a criança vive intensas descobertas relacionadas ao meio ambiente, saúde, cuidado com o corpo e explora assim suas potencialidades.

Em função da alteração no estilo de vida da população, levando ao sedentarismo, obesidade e outros fatores que potencializam o surgimento de doenças crônico-degenerativas, as quais têm atingido toda população, em especial crianças e adolescentes, a prática de atividades físicas torna-se crucial para melhorar a vida das pessoas frente a essa interface (RESENDE, 2013). É fato que cada vez menos esse público jovem tem praticado atividades 
físicas, e no interior da unidade escolar a própria disciplina de Educação Física representa uma área da saúde que visa a prática de atividade física. Sobre isso Guedes aborda:

“Os programas de educação para a saúde representam, sem ignorar a significativa participação dos aspectos biológicos, um problema fundamentalmente de domínio didático-pedagógico e, de maneira particular, em razão das características do objeto de estudo de cada área do conhecimento vinculada à estrutura escolar, a disciplina de educação física”. (1999, p.11).

Na promoção da saúde, principalmente, na escola, Resende (2013, p.16) destaca que "o compromisso não cabe apenas à realização das atividades pela alteração das condições de saúde e doença, fato este visto como irreal, pois as alterações biológicas provocadas pelos exercícios não são necessariamente sinônimo de saúde".

Será abordada no próximo item essa relação da EF escolar com a saúde dos educandos.

\subsubsection{A Saúde no contexto da Educação Física escolar}

Como já citado nas abordagens pedagógicas, a saúde se faz presente na EF escolar como modelo defendido por autores para serem aplicados como propostas de ensino e cumprimento a diversos objetivos. Destacam-se como seus principais defensores Markus Vinicius Nahas, Dartagnan Pinto Guedes e Joana Elisabete Ribeiro Pinto Guedes.

A EF, em sua definição, deve trabalhar a corporeidade, o movimento, a socialização, as potencialidades e a obtenção de qualidade de vida. Em vista de grande parte das aulas se constituírem de exercícios físicos, a sua representatividade e compromisso com a saúde dos alunos faz-se natural e de extrema importância. É a disciplina que representa a melhoria das condições de vida para crianças e jovens. Sendo prova disso é importante destacar:

A atividade física é componente importante de um estilo de vida saudável, com inúmeros benefícios relacionados à saúde. A escola oferece um cenário favorável para a promoção da atividade física, contribuindo para a saúde dos adolescentes e diminuindo fatores de risco para doenças crônico-degenerativas (TENORIO; TASSITANO; LIMA, 2012, p. 308).

Guedes (1999) propõe que a escola, por meio das aulas de EF, desenvolva programas em que os alunos percebam a importância de um estilo de vida saudável atrelado à prática de atividade física como componente habitual de seu cotidiano. Assim, os professores têm por função desenvolver atividades não exclusivas à parte esportiva ou recreativa, mas também alcançarem metas voltadas à educação para saúde, organizando situações em que o aluno se 
conscientize das consequências do exercício físico na sua vida e na saúde, e passa a adotá-lo como parte de sua rotina (um indivíduo fisicamente ativo).

O surgimento de novas opções, tais como as atividades lúdicas vêm atingindo o público infantil e adolescente, e as atividades que envolvem algum esforço físico vêm sendo substituídas por jogos e brinquedos eletrônicos (GUEDES, 1999). Isso é evidente ainda mais nos dias atuais com o surgimento de tablets, celulares, dentre outros aparelhos que proporcionam atrativos e jogos de realidade virtual que prendem a atenção do público escolar.

Dada a relevância desse fato, é preciso conscientizar, desde a infância e adolescência, sobre os níveis de aptidão física relacionados à saúde e levá-los por toda vida. Assim, é necessário que a EF proporcione ao aluno informações compreensivas sobre conceitos do por que e como praticar a atividade física e não realizá-la pelo simples fato de praticar (GUEDES, 1999).

"Para alcançar esses objetivos, a corrente da Aptidão Física Relacionada à Saúde defende que a educação física não esteja atrelada exclusivamente ao desporto" (FERREIRA, 2001, p.44). A EF deve criar e despertar nos alunos o gosto e o prazer pela prática regular de atividade física, sendo eles, ao longo da vida, capazes de selecionar essas atividades, avaliar os seus níveis de aptidão e, quanto maior esse nível, maior autonomia na prática de exercícios (FERREIRA, 2001).

Cabe ressaltar que essa relação da EF escolar com a saúde possui duas concepções. A primeira está atrelada aos aspectos biomédicos, ou seja, os benefícios da atividade física ligados a melhoria de variáveis fisiológicas, como destaca Guimarães (2009), a melhoria cardiovascular, cardiorrespiratória, pressão arterial, tônus muscular e melhora da disposição e do bem-estar.

A segunda concepção como já citada, diz respeito à Aptidão Física Relacionada à Saúde, na qual o aluno participe de outros conteúdos, que não somente o esporte nas aulas de EF. Ferreira (2001) acentua que o esporte deve ser trabalhado juntamente com a atividade física regular (do cotidiano), que ensine além de técnicas e regras a realizar atividades de forma autônoma com segurança e eficiência, para tanto, sendo necessário o trabalho de conteúdos de mais campos, como: fisiologia, biomecânica, nutrição e anatomia. Em função disso, o aluno aprende, como propõe os objetivos da disciplina, o conhecimento do próprio corpo e como utilizá-lo em benefício próprio no seu cotidiano.

Um exemplo que o mesmo autor traz é em relação ao Atletismo, na parte de corrida. Para o aluno, obter autonomia em relação a essa prática, além da técnica, regras e histórico, faz-se necessário trabalhar os demais conteúdos como a importância da frequência cardíaca 
durante o exercício, o monitoramento do esforço, a melhor forma de respiração, a vestimenta adequada, a alimentação necessária e a hidratação correta durante a corrida, as formas e a importância do aquecimento, as contra indicações da atividade e até mesmo uma discussão sobre sua relação com o emagrecimento (FERREIRA, 2001).

No ambiente escolar é comum (no ensino fundamental anos finais) perceber o domínio das atividades esportivas como conteúdo principal nas aulas de EF (FARIAS et al., 2017). Se refletirmos sobre nossas próprias aulas de EF ou visitarmos uma aula, em sua grande maioria o conteúdo se dará em torno das práticas de esportes. Contudo, é importante que o professor tenha a sensibilidade de despertar, como já citado pelos autores anteriormente, o interesse pela prática da atividade física, atribuindo significância àquele conteúdo na vida do aluno. Bento (2010) recorda que um dos objetivos do esporte é a saúde, porém, sua missão vai além, ele parte da cultura, é uma arte e uma prática que ajuda o homem a constituir-se em uma condição social, moral, cultural e reflexiva. Com isso, é possível compreender que mesmo o predomínio do esporte é possível transformar a realidade do aluno conscientizando-o sobre a importância da EF como promotora da saúde. O esporte se transforma em meio para este fim.

Portanto, "o desenvolvimento de atitudes positivas em relação à atividade física relacionada à saúde, durante os anos de escolarização, é importante requisito para participação voluntária mais efetiva na idade adulta" (GUEDES, 1999, p. 13) e o que mais contribui para isto são as aulas de EF.

Considerando-se que a EF é a disciplina que possui importante papel na saúde dos alunos, o profissional que por ela é responsável tem a grande missão de promover a concretização dos propósitos da disciplina para com os alunos. É o professor de EF que irá a cada aula planejar, propor e dirigir as atividades que possam, por meio do exercício, contribuir para melhoria da qualidade de vida no contexto das crianças e dos adolescentes.

Ferreira (2001) afirma que ao adotarem estratégias que não permitam o aluno enxergar os diversos significados que envolve uma atividade, os professores perdem a oportunidade de conscientizar os alunos e significar o conteúdo em suas vidas, sendo que alguns podem se interessar e engajar-se na prática continuada, como outros não e se distanciem dela. Portanto, deve sempre trabalhar na perspectiva não isolada às técnicas ou aptidões físicas, mas significar a atividade como beneficiária a saúde e outras questões sociais.

Como foi visto "a educação física não pode perder de vista o caráter multifatorial da saúde e, portanto, da qualidade de vida. Como disciplina escolar, ela não deve abandonar sua preocupação em subsidiar e encorajar as pessoas a adotarem estilos de vida ativa" (FERREIRA, 2001, p. 49). 
A obesidade atinge grande parte da população e índices de aproximadamente $82 \%$ apontam as causas em sedentarismo e má alimentação. Atualmente, crianças e adolescentes possuem um estilo de vida pouco saudável devido ao sedentarismo e à alimentação rica em conservantes e gorduras (SEVERINO; SILVA, 2014). As tecnologias como computadores e vídeo games ganham a preferência em relação a brincadeiras que envolvam movimento e relação com o corpo (correr, subir em árvores, dançar, etc.). E, estando os alunos presentes na escola boa parte do seu dia, a EF pode e deve contribuir para o incentivo à prática de exercícios, de forma autônoma e baseada no contexto em que vive para melhora de um estilo de vida mais saudável.

Torna-se evidente em todo conteúdo bibliográfico presente neste trabalho que a EF faz-se de extrema importância na vida e no desenvolvimento do aluno como um cidadão. Contudo, a disciplina apresenta uma trajetória de desvalorização, de perda de seu verdadeiro significado em meio às escolas. Assim, este estudo objetiva analisar a motivação dos alunos no Ensino Fundamental e a relação da disciplina com a promoção da saúde em suas vidas. Ouvir os alunos, concluintes do ensino fundamental, e entender o que significa e representa a EF para eles, apesar desse quadro decrescente, os estudos e as reflexões poderão indicar caminhos que ajudem a reverter a situação e melhorar a prática da disciplina e o olhar institucional sobre a mesma.

Atualmente, apesar dessa tendência forte de associar EF e saúde, das diversas diretrizes, teorias, contribuições implícitas e explícitas para a formação das crianças e jovens, evidências científicas e empíricas, a EF escolar ainda não se afirmou na educação desse público. Em se tratando de educação e saúde o país não possui a cultura da emancipação e prevenção respectivamente, a mudança só ocorre quando o problema se torna evidente. Sendo assim, a EF como prevenção e uma maneira de qualidade de vida pode ser um embrião que dará frutos no futuro.

\section{MÉTODO}

Caracteriza-se uma pesquisa qualitativa de campo, isto é, não houve mensuração estatística de dados coletados, mas análise de temas em relação ao objetivo abordado, com dados descritivos em contato direto do pesquisador com o objeto de estudo (NEVES, 1996).

É importante destacar que toda pesquisa qualitativa é caracterizada pela análise de micro processos em estudos de ações sociais tanto individuais quanto grupais e um exame 
intensivo dos dados em amplitude e profundidade. Neste tipo de pesquisa existe a preocupação em aproximar-se dos dados de forma completa, para que nessa interação com os dados possa-se aprender e compreender a realidade social (MARTINS, 2004).

Se há uma característica que constitui a marca dos métodos qualitativos ela é a flexibilidade, principalmente quanto às técnicas de coleta de dados, incorporando aquelas mais adequadas à observação que está sendo feita (MARTINS, 2004, p. 292).

Na pesquisa qualitativa é importante frisar que há forte heterodoxia dos dados, isto é, variedade de material que exige do pesquisador capacidade integrativa e analítica. Deve-se analisar e atribuir os significados aos dados com cautela à questão ética, pois pode haver certa proximidade (mesmo que somente física) com os pesquisados e não reforçar ideologias existentes, mas promover instrumentos para desvendá-las e superá-las (MARTINS, 2004).

$\mathrm{O}$ intuito na pesquisa qualitativa deste estudo foi, portanto, analisar e interpretar os dados, contextualizando-os e sem necessidade de generalizar (TRIVINOS, 1992). Convém ressaltar também que a pesquisa nos permitiu conhecer o contexto recortado a partir do depoimento dos participantes.

As entrevistas iniciaram após aprovação do Comitê de Ética em Pesquisa (CEP) da Escola de Educação Física e Esporte de Ribeirão Preto (EEFERP) - USP, sob parecer $n^{\circ}$ 1.938.879, em 22 de fevereiro de 2017, o qual consta no Anexo A deste material.

\subsection{Participantes da Pesquisa}

A pesquisa foi apresentada em uma sala de $9^{\circ}$ ano, escolhida aleatoriamente dentre as três disponíveis deste ciclo no período da manhã, de uma escola pública municipal de Ribeirão Preto/SP. Esses jovens estão encerrando um ciclo acadêmico e, consequentemente, possuem bagagem de toda trajetória de ensino na instituição, inclusive em relação à EF. A sala possuía aproximadamente trinta alunos e a intenção era selecionar aproximadamente dez que cumprissem os requisitos de seleção.

Os requisitos de seleção eram: ser aluno regularmente do $9^{\circ}$ ano, ter iniciado seus estudos na referida escola desde o $1^{\circ}$ ano do ensino fundamental e estar na faixa etária aproximada correspondente ao ano (ciclo) letivo.

Com os requisitos de seleção, o número de participantes ainda era superior ao pretendido de aproximadamente dez alunos. Foi então realizada uma explicação detalhada sobre a pesquisa para este pequeno grupo, e aberto o convite para aqueles que gostariam de 
contribuir, sendo que nove se prontificaram. É importante destacar que dois alunos, de outra sala de $9^{\circ}$ ano, ao saberem da pesquisa por intermédio de uma professora, se interessaram pelo trabalho e, como preenchiam os requisitos, integraram o grupo dos selecionados.

Para as entrevistas foram selecionados onze (11) alunos, meninos e meninas, que cumpriam todos os requisitos apresentados. A idade desses jovens foi entre 14 e 16 anos, considerando aqui a tolerância de até um ano de repetência ou mesmo transição do ensino de oito para nove anos (que pode interferir na idade com o ano letivo que ele cursa).

Todos eles receberam informações sobre a pesquisa, seus propósitos, importância e contribuições, bem como a apresentação do pesquisador e poderiam aceitar ou não o convite.

Portanto, Os onze alunos, que cumpriam os requisitos, confirmaram seu interesse em participar das entrevistas e ratificaram o aceite ao convite.

Os participantes foram cinco alunas do sexo feminino e seis alunos do sexo masculino. O número dentre os gêneros também se mostrou ideal para não haver tendências desse caráter, uma vez que estudos (de gênero na EF) como de Jaco (2012) destacam que meninos tendem a gostar mais da EF do que as meninas. Contudo, muitas opiniões e preferências dos alunos se manifestaram nos resultados, independente do gênero.

Para a preservação da identidade dos participantes adotou-se a sigla $\mathrm{S}$, referente ao sujeito, e o número de um a onze (referente ao total de entrevistados). A ordem de atribuição da nomenclatura foi de acordo com aquela em que ocorreram as entrevistas, por exemplo, ao primeiro aluno entrevistado foi nomeado a referência $\mathrm{S} 1$, ao segundo $\mathrm{S} 2$ e assim sucessivamente.

\subsection{Local de pesquisa: A Escola}

Para descrever o local da pesquisa, ou seja, onde ocorrem as aulas de EF que os participantes da pesquisa frequentam, foi utilizado o PPP da Escola que vai de 2014 a 2017.

A escola selecionada para pesquisa está localizada na cidade de Ribeirão Preto - SP e é uma instituição de ensino pública administrada pelo município. Foi fundada no ano de 1962 e funcionava apenas no período tarde com ensino de $1^{\mathrm{a}}$ a $4^{\mathrm{a}}$ série na época. Apenas em 1969 passou a atender $1^{\circ}$ e $2^{\circ}$ grau. A escola está localizada no bairro Campos Elíseos, que é caracterizado por grande área residencial, pequenos comércios, hospitais e até centros universitários. O fluxo de transporte público é intenso e utilizado pela maioria dos alunos da 
escola. Sendo sua localização em um ponto de fácil acesso, existem diversas classes sociais (variam de baixa à média baixa) que atende vários bairros de Ribeirão Preto.

A instituição oferece Ensino Fundamental: dos anos iniciais ( $1^{\circ}$ a $5^{\circ}$ ano) e anos finais ( $6^{\circ}$ a $9^{\circ}$ ano), bem como a Educação de Jovens e Adultos (EJA) e Educação Especial. A faixa etária dos alunos do Ensino Fundamental varia, portanto, de 5 e 6 anos a aproximadamente a 14 e 15 anos, quando finalizam este ciclo e avançam para o Ensino Médio. Atualmente, o núcleo discente é de aproximadamente 1500 alunos, sendo eles tanto do Ensino Fundamental quanto da EJA. Para os anos finais (de $6^{\circ}$ ao $9^{\circ}$ ) contabiliza-se cerca de 550 crianças/jovens.

A escola funciona regularmente com aulas de segundas às sextas-feiras nos períodos da manhã e tarde com Ensino Fundamental (anos iniciais e finais), bem como Educação Especial, e EJA no período noturno (também com anos iniciais e finais).

A escola possui três quadras poliesportivas para as aulas de Educação Física, dois vestiários (masculino e feminino) localizados próximos às quadras e uma sala de materiais esportivos para os professores.

Assim como as demais escolas sob o regimento municipal, os alunos possuem três aulas semanais de Educação Física (em todos os ciclos/anos), sendo organizadas de acordo com a melhor opção de horários feitas anualmente pela direção. Grande parte das aulas nesta escola é organizada para que cada sala possua uma aula dupla e uma simples na semana.

Por ser uma escola de grande porte, que possui vários níveis de ensino, o número de professores é proporcional, pois há diversas áreas de conhecimento. Para a EF, são aproximadamente quatro ou cinco professores que atendem às aulas nos períodos da manhã e da tarde. Para o período da manhã havia (no ano de 2017) três professores efetivos (concursados) e dois eventuais (que possuem contrato por tempo determinado). Um dos professores efetivos, inclusive que rege a EF dos alunos participantes, ministra aula na unidade escolar há mais de 20 anos, o outro professor há mais de 10 e a outra professora (que na ocasião trabalhava com o ensino fundamental anos iniciais) possui aproximadamente cinco anos. Os professores eventuais integraram o quadro de professores apenas no referido ano para suprir algumas aulas.

Os docentes efetivos com mais de 10 anos na instituição são formados nas décadas de 80 e 90, ou seja, há mais de 20 anos, enquanto a professora com menos tempo possui aproximadamente 10 anos de formada. Todos os docentes efetivos possuem apenas essa fonte de renda, ou seja, são funcionários apenas da Prefeitura de Ribeirão Preto e, possuem carga horária de trabalho de 38 horas/aula (carga máxima permitida para a categoria de professor especialista). 
Quanto aos professores eventuais, são mais novos e com formação que remontam aos últimos cinco ou dez anos aproximadamente, e possuem contratos por tempo determinado com a prefeitura. Eles geralmente atuam em mais de uma escola e sua carga horária varia de acordo com aulas disponíveis. Essas aulas atribuídas a esses professores são aulas de substituição por motivos como: aposentadoria, licenças prêmio ou médicas, defasagem docente no quadro funcional, etc.

A instituição de ensino sempre foi considerada uma das mais conhecidas e modelo dentre as escolas municipais de Ribeirão Preto. A escola já atendeu também o Ensino Médio, porém, com a transferência de responsabilidade dessa categoria para o Estado, este ciclo de ensino se encerrou na instituição com sua última turma em 2014. Passou por uma reforma predial no ano de 2006 para melhor atender a comunidade escolar.

\subsection{Produção e Análise de Dados}

Em um primeiro momento, e para reconhecimento do público na sala escolhida do $9^{\circ}$ ano, foi feita uma observação dos alunos em algumas aulas de Educação Física. A partir dessas observações foram elaboradas algumas perguntas para a entrevista. É importante destacar que os alunos não tinham aula com o pesquisador, apenas o conheciam como um dos docentes da instituição.

Foram realizadas entrevistas semiestruturadas que, segundo Gil (2008), possibilitam ter contato com a realidade vivida pelos atores, e uma forma flexível para coleta. Essas entrevistas com os alunos seguiram um roteiro com perguntas abertas que incluíam temas como motivação, participação nas aulas, relação professor/aluno, esportes e atividade física no geral. Com isso, permitiu-se que e o entrevistado falasse livremente sobre determinado tema ao qual foi questionado (GIL, 2008).

Um roteiro (Anexo B), foi elaborado para a realização das entrevistas, com base em obras de autores como Boni e Queresma (2005) e Tolei e Mazine (2013), e cujas perguntas permearam assuntos e objetivos do trabalho. Este roteiro não foi seguido na íntegra para todas as entrevistas para que o aluno tivesse mais liberdade para se expressar, foi usado para orientar a entrevista de modo a garantir o conteúdo de interesse.

Inicialmente realizou-se um piloto com dois alunos, a fim de analisar o andamento e os procedimentos da pesquisa. O piloto se mostrou favorável aos objetivos, os alunos apreciaram o momento, não apresentaram dificuldades em relação ao diálogo desenvolvido e deu-se 
continuidade à proposta da pesquisa com os demais. É valido ressaltar que esses dois alunos que foram piloto fizeram parte dos resultados obtidos e inclusos no trabalho.

As entrevistas foram gravadas com cada aluno (individualmente), no próprio local e período de estudo e de preferência no momento das aulas de Educação Física. Foi utilizado um gravador digital, e seguindo o roteiro elaborado nos temas explorados por este trabalho, o aluno foi expressando seu parecer sobre os temas questionados. É importante destacar que antes da gravação o pesquisador explicou ao aluno como funcionaria a pesquisa, frisando que a gravação não seria divulgada e tampouco sua identidade revelada no trabalho. Além disso, com a finalidade de tranquilizar e deixar o aluno mais à vontade houve uma apresentação sobre a vida do pesquisador como aluno de EF da própria escola (em questão) e como isso o despertava curiosidade para descobrir novas realidades e situações que acontecem atualmente com essa geração e a EF escolar. Embora o aluno possa ter feito comparações entre a sua vivência e a do pesquisador, essa abordagem inicial prestou-se a familiarizar o depoente com o processo da pesquisa.

É importante ressaltar que durante as entrevistas procurou-se deixar o entrevistado a vontade para falar o que sentisse em relação à questão ou até mesmo entrar em outros méritos que achasse válido para tal questionamento, mesmo com a presença do roteiro. Em se tratando de um público de adolescentes na faixa etária dos 14 a 16 anos, é possível deparar-se com certa resistência para se expressar, questionar ou debater sobre determinado assunto, sendo necessária a intervenção em alguns momentos para estimular a manifestação dos depoentes. Ainda que alguns tenham demonstrando boa comunicação e expressão, outros se mostraram tímidos e breves em algumas respostas (com grande variação no tempo de entrevista).

As entrevistas tiveram em média 15 minutos de duração, a de maior tempo foi de aproximadamente 21 minutos e a menor tempo 8 minutos.

\subsubsection{Análise Temática}

Para o tratamento de dados foi realizada a Análise Temática, que é um método para identificar e analisar padrões em dados de pesquisas qualitativas, sendo ele flexível, não se encontra vinculada a teorias pré-existentes, funciona com grandes ou pequenos conjuntos de dados e muito usado para diferentes tipos de dados e entrevistas transcritas (CLARKE; BRAUN, 2013). 
A análise temática faz-se adequada para interesses de pesquisa e perspectivas teóricas, além de ser um método "básico", pois, possibilita o trabalho sobre experiência e entendimento de pessoas sobre fenômenos e contextos particulares, analisar transcrições de grupos específicos ou entrevistas e também produzir análise orientadas por dados ou baseadas em teorias (CLARKE; BRAUN, 2013).

Esse tipo de análise reportará temas sobre os dados coletados, organizando e descrevendo um conjunto de informações em detalhes, além disso, é um método que pode reportar experiências e realidades de entrevistados, bem como contextualizar maneiras que os indivíduos fazem a significância de suas experiências (BRAUN; CLARKE, 2006). Em vista dos objetivos deste trabalho e da forma escolhida para coleta dos dados, a análise temática com sua proposta se fez adequada.

É necessário na análise temática um processo de decisões para que as discussões e considerações se tornem possíveis. Essas questões devem ser realizadas antes da análise (ou antes da coleta em alguns casos) para que haja um diálogo reflexivo contínuo por parte do pesquisador durante o processo de análise dos dados e ao que pesquisa se refere (BRAUN; CLARKE, 2006). As autoras apontam como indagações as seguintes: O que seria um tema?; Uma descrição rica dos dados ou um relato detalhado de um aspecto particular?; Análise temática indutiva ou teórica?; Tema semântico ou latente?; Epistemologia: essencialista/realista ou análise temática construcionista?. Detalharemos a seguir essas questões apresentadas.

Em relação ao tema, este se apresenta como um significado padronizado dentro do conjunto de dados que se obteve. Idealmente há um número de instancias do tema nos dados, contudo o aparecimento em mais ou menos instancias não se faz crucial para definição deste tema, é necessário o julgamento do pesquisador e se captura algo importante em relação aos objetivos da pesquisa. Inicialmente este estudo traz o tema: motivação na EF escolar, que remonta às questões centrais do estudo e servirá como sustento para emergir os novos temas. Com relação ao segundo questionamento: descrição rica ou relato detalhado de aspecto particular, o primeiro ponto ressalta uma rica descrição temática de todo conjunto de dados, a fim de determinar as reivindicações que irão emergir e serão utilizadas em áreas pouco exploradas. Sobre o relato detalhado, que utilizamos neste estudo, está relacionado a um tema específico (questão) ou grupo de temas presente nos dados analisados (BRAUN; CLARKE, 2006), o que aqui destacamos da pesquisa: as aulas de EF escolar.

$\mathrm{O}$ outro questionamento refere-se à uma análise indutiva ou teórica, sendo que na primeira os temas identificados estão fortemente ligados aos dados e com alguma semelhança 
à teoria fundamentada, esses temas não se enquadram em interesses teóricos prévios do pesquisador.

Em contrapartida a análise teórica tende ao interesse analítico do pesquisador e seu direcionamento é explícito, sendo uma análise mais detalhada de algum aspecto dos dados. Em virtude de que a motivação na $\mathrm{EF}$ escolar sofre influência de vários fatores, além do envolvimento de diversos agentes e do ambiente a decisão desse estudo se fará pela análise teórica, que se pode por meio da permissividade do pesquisador desenrolar os dados para que se inclua e expanda outros temas em torno do original (BRAUN; CLARKE, 2006).

As autoras detalham também a escolha do nível semântico ou latente, sendo o primeiro a identificação dos temas em significados explícitos ou superficiais dos dados, sem ressaltar qualquer coisa além do que o entrevistado disse ou escreveu. Por outro lado, o semântico envolve o desenvolvimento dos temas a partir do modo interpretativo dos dados, seguindo uma tendência construtivista. A princípio, pela transcrição das entrevistas usa-se o modo semântico, contudo faz-se a opção neste estudo pelo nível latente em função do público participante se pautar em falas reduzidas ou pouco compreensíveis em alguns pontos.

Por fim, a questão epistemológica essencialista/realista, refere-se a uma relação unidirecional entre o significado e o que é dito, enquanto a construcionista considera a produção e reprodução social dos significados e experiências, não sendo inerentes somente ao sujeito, mas a todo contexto sociocultural e estrutural (BRAUN; CLARKE, 2006). Como os aspectos motivacionais, sejam eles intrínsecos ou extrínsecos, sofrem influência do meio social e dos agentes envolvidos se faz proveitoso o uso epistêmico construcionista.

Ao iniciar a análise dos dados, após a transcrição das entrevistas, a análise temática prevê o processo de codificação que irá buscar e identificar padrões de significados no conjunto de dados, os quais originarão os temas. Braun e Clarke (2013) destacam seis fases para a análise, observe:

a) Familiarização com os dados: conhecer os dados coletados por meio de leituras e releituras ou escutas de áudios, anotando informações iniciais relevantes; estar intimamente familiarizado aos dados.

b) Codificação: definição de rótulos concisos dos dados relevantes à questão da pesquisa, bem como o agrupamento dos códigos e dados relevantes de cada um.

c) Procurando temas: o tema é um padrão coerente e significativo nos dados que são relevantes ao objetivo da pesquisa, o pesquisador constrói os temas a partir da identificação de semelhança nos dados por meio dos códigos. 
d) Verificação dos temas e sua relação com os dados e os códigos identificados, além disso, se reflete a natureza individual de cada tema e a relação entre eles.

e) Definindo e nomeando temas: processo em que o pesquisador conta a história de cada tema e como ele se encaixa nos dados analisados. Em seguida há a elaboração de um nome conciso e informativo para cada tema.

f) Escrevendo o relatório: é a etapa final que envolve a confecção da narrativa analítica e coerente dos extratos vividos, bem como retornar essa análise à questão da pesquisa e contextualizá-la com a literatura existente.

Seguindo as fases da análise temática, após a transcrição das entrevistas com os alunos (na íntegra) foram realizadas várias leituras e em seguida a geração dos códigos e dados significativos (codificação). Os temas emergidos a partir dos códigos foram então revisados e identificados sua relação com os dados e, então nomeados e detalhados. Ao final de toda análise houve a discussão entre a narrativa dos dados, em meio aos temas emergidos, com a literatura existente.

\section{RESULTADOS}

Esta sessão aborda a análise das entrevistas, e aponta os temas que emergiram entre os 11 alunos e, por meio deles, procuramos entender os fatores que impactam na motivação desses alunos para as aulas de EF, como eles percebem a importância dessa prática para sua vida e se a saúde é um fator de conscientização que (re)signifique a importância da disciplina e possa ser aprimorada.

O cenário das aulas de EF foi relatado pelos alunos no decorrer do diálogo. Em diversos pontos das entrevistas foi possível identificar aquilo que é de maior ou menor apreço dos estudantes, o que na opinião deles está em falta na EF escolar, como é conduzida a aula e um breve comparativo de suas experiências em anos anteriores.

Para que se possa conhecer um pouco sobre o aluno a que o depoimento/discussão se refere, o quadro 3, apresenta uma síntese do perfil de cada um.

Quadro 3 - Perfil dos alunos. 


\begin{tabular}{|c|c|c|c|c|}
\hline $\begin{array}{c}\text { Características/ } \\
\text { Sujeitos }\end{array}$ & Idade & Gênero & $\begin{array}{c}\text { Local de } \\
\text { Residência } \\
\text { (Bairro) }\end{array}$ & $\begin{array}{c}\text { Atividade Física Extra } \\
\text { Curricular que pratica ou } \\
\text { praticou }\end{array}$ \\
\hline S1 & 14 & Masculino & Campos Elíseos & Nenhuma \\
\hline S2 & 14 & Feminino & Campos Elíseos & Academia \\
\hline S3 & 15 & Feminino & Centro & Vôlei (treinamento) \\
\hline S4 & 15 & Feminino & Campos Elíseos & Nenhuma \\
\hline S5 & 14 & Masculino & Campos Elíseos & Futebol (treinamento) \\
\hline S6 & 16 & Masculino & Vila Tibério & Futebol (como lazer) \\
\hline S7 & 15 & Masculino & Campos Elíseos & Nenhuma \\
\hline S8 & 15 & Feminino & Campos Elíseos & Nenhuma \\
\hline S9 & 15 & Masculino & Campos Elíseos & Judô (treinamento) \\
\hline S10 & 15 & Feminino & Campos Elíseos & Vôlei (como lazer) \\
\hline S11 & 15 & Masculino & Campos Elíseos & Nenhuma \\
\hline
\end{tabular}

Por meio desse primeiro quadro percebe-se que, dentre os adolescentes entrevistados, nove moram na mesma região de localização da escola em que estudam. Por meio do quadro é possível perceber a predominância do esporte em meio às atividades físicas (praticado pela maioria, cerca de 50\% dos entrevistados), discussão que se fará presente no estudo em meio às preferências destacadas pelos alunos durante as aulas.

Durante o período de entrevistas com os participantes, desde o piloto (dois primeiros) até os nove restantes, houve um acontecimento que acabou resultando em uma divisão simbólica e não intencional do grupo que foi a mudança do professor de EF. Assim que se encerrou o primeiro semestre do ano letivo, os alunos entraram de férias e o professor regente da disciplina de EF aposentou-se, professor que estava há aproximadamente vinte anos ou mais na instituição. O professor que o substituiu é regido por contrato temporário e iniciou os trabalhos a partir do retorno das aulas no segundo semestre. Tal fato faz-se importante destacar, pois houve diferença na fala dos alunos sobre suas aulas em virtude dessa mudança. Sendo assim, o primeiro grupo, que antecedeu a mudança, compreende do aluno S1 ao S5, enquanto os demais do S6 ao S11 foram entrevistados após a mudança de professor (segundo grupo).

A fim de elucidar melhor o processo de análise temática dos dados produzidos nas entrevistas, seguem os códigos extraídos, a partir do tema inicial "motivação", que foram significativos para a construção dos temas e das discussões. 
Conforme a análise das leituras, os rótulos identificados e significativos para a formação dos temas e que refletem na questão da pesquisa foram: "Tempo livre", "praticar esportes", "fazer exercício", “Aprender esportes”, "professor não passa nada”, "mexer no celular", "competição", "melhorar a saúde", “aliviar tensão", "aula livre”, "prática por prazer", “esportes coletivos: futebol, vôlei e basquete”, “jogos: queimada, base 4", "gosto muito das aulas", "não gosto de competição", "movimentar-se", "o professor agora explica", "antigamente havia mais atividades", "meninos praticam mais", "futebol predomina", “conteúdo aleatório", conteúdos repetitivos.

A partir dos códigos e semelhança entre eles pode-se produzir quatro temas, os quais serão detalhados posteriormente:

1) Representatividade da EF escolar: tempo livre e práticas esportivas;

2) O conteúdo da aula: "aula livre", conteúdo dirigido e o papel do professor;

3) A família e as vivências no esporte;

4) A saúde;

Para melhor leitura e compreensão primeiramente foi apresentado um quadro síntese dos resultados com pontos principais abordados, em seguida, a discussão com a literatura foi realizada em conjunto à descrição de cada tema e apresentação de alguns depoimentos que melhor retratam cada assunto em questão. 


\subsection{Sumário dos Resultados}

Quadro 4 - Resumo dos resultados

\begin{tabular}{|c|c|c|}
\hline TEMAS & DEPOIMENTOS & LITERATURA \\
\hline \multirow{4}{*}{$\begin{array}{l}\text { Representatividade da } \\
\text { Educação Física Escolar }\end{array}$} & \multicolumn{2}{|c|}{ Subtema: Tempo Livre } \\
\hline & $\begin{array}{l}\text { "Para mim é um tempo livre que a gente tem fora da sala } \\
\text { de aula" (S4). } \\
\text { "Para mim é como se fosse um descanso das aulas, tipo, } \\
\text { não ficar muito na sala de aula, um jeito de distrair } \\
\text { também" (S8). }\end{array}$ & $\begin{array}{l}\text { Ruptura com o ambiente cognitivo (NISTA-PICCOLO; } \\
\text { MOREIRA, 2012). } \\
\text { Os diversos conteúdos, diversão, tudo melhor do que estarem em } \\
\text { sala de aula (ESPÍNDULA et al., 2014). } \\
\text { Prática do "rola a bola" (PEREIRA; SILVA, 2010). }\end{array}$ \\
\hline & \multicolumn{2}{|c|}{ Subtema: Prática Esportiva } \\
\hline & $\begin{array}{l}\text { "Eu acho que é uma aula que você tem jogos esportivos } \\
\text { (S7)". } \\
\text { "Representa um esporte (S10)". } \\
\text { "Representa praticar esportes, tipo, conhecer vários } \\
\text { esportes (S5)". }\end{array}$ & $\begin{array}{l}\text { Predomínio de práticas esportivas (GUEDES, 1999). } \\
\text { Influência dos métodos ginásticos (SOARES, 2007). } \\
\text { A EF e o ato de ensinar esporte fizeram-se sinônimos (PIMENTA; } \\
\text { HONORATO, 2010). } \\
\text { Alunos perdem motivação por conteúdos repetitivos e predomínio } \\
\text { de técnicas esportivas (NETO et al., 2010). }\end{array}$ \\
\hline & \multicolumn{2}{|c|}{ Subtema: Aula livre predomina } \\
\hline O conteúdo da aula & $\begin{array}{l}\text { “[...] o professor não dá mais o que ele dava,... aí o } \\
\text { pessoal fica mais no celular, fone de ouvido }[\ldots] ”(\text { S3). } \\
\text { “[...] não tem aula específica de um esporte, eu posso }\end{array}$ & $\begin{array}{l}\mathrm{Na} \text { "Aula livre" ou prática de "rola a bola" os alunos realizam um } \\
\text { esporte ou atividade qualquer sem objetivo didático } \\
\text { (NASCIMENTO; GARCES, 2013). }\end{array}$ \\
\hline
\end{tabular}




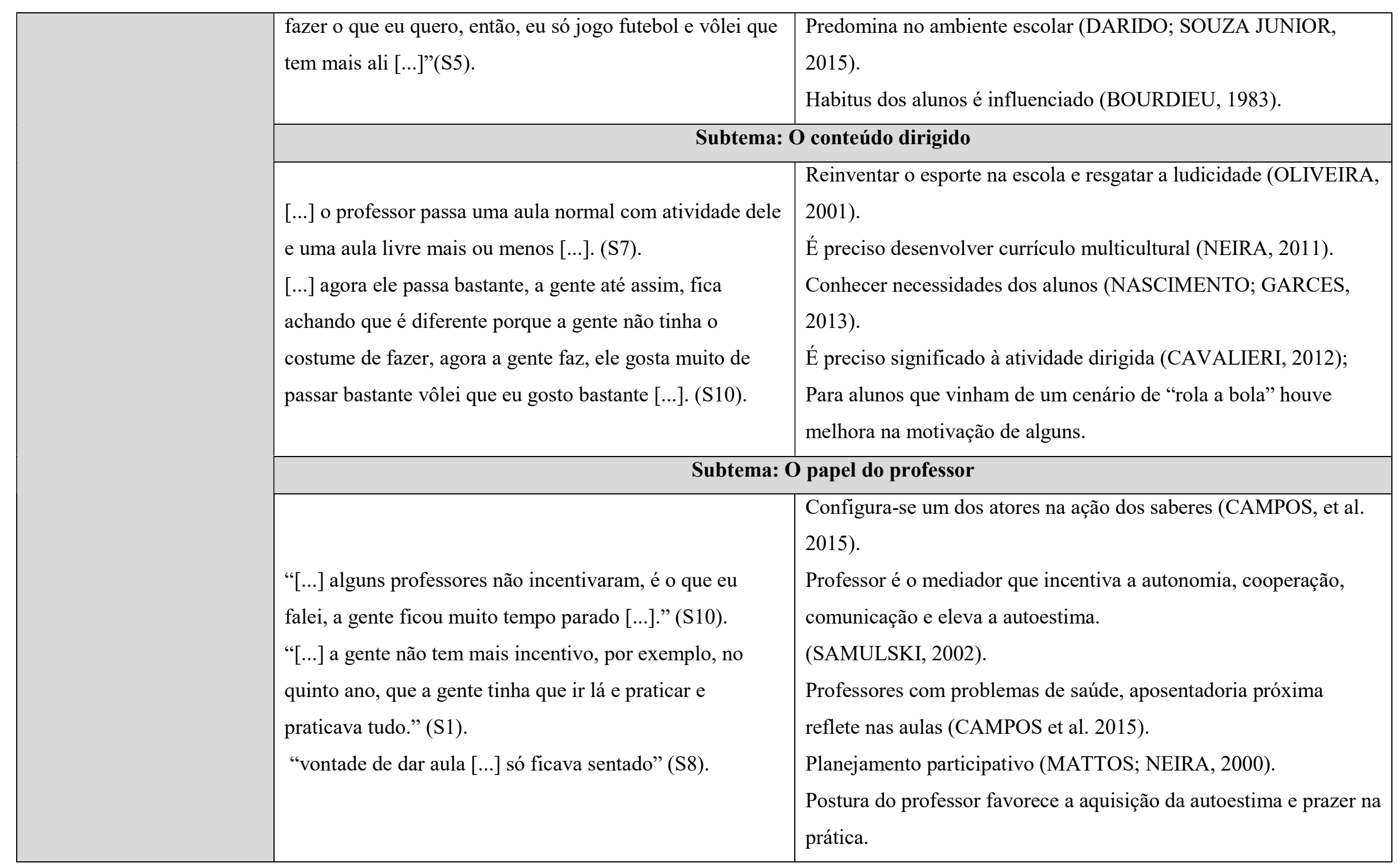




\begin{tabular}{|c|c|c|}
\hline $\begin{array}{c}\text { A família e as vivências } \\
\text { no esporte }\end{array}$ & $\begin{array}{l}{[\ldots][\ldots] \text { o meu vô, o meu vô me apoia assim, é o mais que }} \\
\text { me apoia, ele me leva para treinar, me fala o que eu tenho } \\
\text { que fazer, que eu tenho que continuar nisso, ele que me } \\
\text { apoia mais. [...] ele foi jogador do Comercial" (S5). } \\
\text { "Meu irmão [...] Ele era competidor também (S9)". }\end{array}$ & $\begin{array}{l}\text { Transformação do “habitus" e acesso a capitais (BOURDIEU, } \\
\text { 1996); } \\
\text { Apoio dos pais crucial para um ambiente favorável para o } \\
\text { engajamento no esporte (NUNOMURA; OLIVEIRA, 2014). } \\
\text { A cultura familiar importante papel no processo "becoming" } \\
\text { (HODKINSON, BIESTA; JAMES, 2007); } \\
\text { Poucos pais acompanham a EF e a enxergam como uma } \\
\text { brincadeira (VIANNA, et al., 2017); } \\
\text { Família: fator motivador (intrínseco) para práticas esportivas e da } \\
\text { EF; }\end{array}$ \\
\hline A saúde & $\begin{array}{l}\text { "O que me motiva mais é a saúde mesmo, porque o fato } \\
\text { de a obesidade no Brasil ser muito grande [...]" (S1). } \\
\text { "[...] eu acho que isso melhora a minha saúde, aí eu } \\
\text { pratico bastante esporte para isso, para a saúde" (S5). } \\
\text { "Ah, saúde em primeiro lugar [...]" (S10). }\end{array}$ & $\begin{array}{l}\text { Experiências positivas em EF } \rightarrow \text { auxilia em estilos de vida } \\
\text { saudáveis (TENORIO, TASSITANO; LIMA, 2012; GUEDES; } \\
\text { GUEDES, 1997). } \\
\text { Gosto e apreciação reflete no indivíduo ativo fisicamente. } \\
\text { A EF escolar precisa criar nos alunos o interesse pela prática } \\
\text { regular de exercício físico e a busca por um estilo de vida saudável } \\
\text { (FERREIRA, 2001). } \\
\text { Pode ser um fator que impulsione à aquisição de motivação } \\
\text { intrínseca. }\end{array}$ \\
\hline
\end{tabular}

Após essa breve apresentação, as sessões que seguem abordam os tema destacados e sua discussão com a literatura. 


\subsection{Representatividade da Educação Física Escolar: tempo livre e práticas esportivas}

Se a EF está presente na vida desses alunos semanalmente em sua grade curricular e rotina escolar, compreender e analisar o significado que ela possui para eles é um fator importante que está ligado à motivação, isto é, ao porquê se pratica tal atividade. Esses significados apresentam-se relevantes na pesquisa para perceber o papel/lugar da EF na vida dos entrevistados, o que ela representa não só no âmbito escolar, mas também no seu cotidiano. Por meio dessas opiniões é possível perceber familiaridade do agente com a prática de atividade física ou sua resistência a ela.

Dentre os depoimentos dos alunos, o que mais se repetiu foram a expressão: "tempo livre" ou como alguns usaram "intervalo das aulas" (aqui referindo-se às demais disciplinas em que eles permanecem em sala) e também muito foi dito em relação ao esporte, seja a prática do mesmo ou o aprendizado.

Em alguns depoimentos dos alunos destacam-se as opiniões: "Um esporte. [...] um esporte sim”. (S10); “[...] é um momento, assim, que é mais livre, eu posso movimentar, fazer o que eu gosto [...]" (S9);

$\mathrm{O}$ aluno poderia dizer o entendimento dele sobre a disciplina em um conceito formal que ele possa ter aprendido ou mesmo expressar sua opinião mediante as suas vivências. Em virtude das respostas obtidas e análise de cada entrevistado o tema se construiu e traz duas vertentes predominantes para reflexão e discussão com a literatura. Assim, foi pertinente separar em subtemas para apresentar os dados e confrontá-los com a teoria.

\subsubsection{A EF como "Tempo Livre"}

Logo no primeiro contato esse tema se faz presente no relato de S1 ao ser questionado: "Para mim elas representam que o momento em que a gente não vai ter uma aula assim sobre, por exemplo, escrever lá na lousa e tal, representa mais uma pausa [...]", assim também como S4 afirma: "Para mim é um tempo livre que a gente tem fora da sala de aula".

O depoimento desses jovens mostra o reflexo da sociedade nos últimos anos em considerar a EF como um momento de diversão, de jogar bola, de coreografias para comemorações festivas, enfim. As aulas são caracterizadas como "rola a bola", na qual o professor fornece a bola e os alunos realizam o que desejarem. Este cenário propicia que o 
conteúdo rico da disciplina seja esquecido e ela seja como uma válvula de escape para as demais atividades desenvolvidas em sala de aula, um descanso (PEREIRA; SILVA, 2010).

De modo similar Espíndula et al. (2014) reforçam esse ponto, em um estudo sobre motivação nas aulas de EF, em que destacou que mesmo sendo uma disciplina com diversos conteúdos, é vista como um tempo livre para os estudantes que se distraem como acham melhor, sendo que tudo para eles é melhor do que estar em sala de aula. É percebido como o conceito de EF se estabelece a partir de interações e evolui o "habitus" dos agentes, assim cria, como destaca Hodkinson, Biesta e James (2007), a cultura de aprendizagem no ambiente e que neste caso apresenta a disciplina com características preponderante ao lazer.

Assim, com o depoimento dos estudantes e os autores levantados, percebe-se a associação feita pelos alunos da EF como um espaço livre e de possível distração, uma vez que a presença de quadras, bolas e um ambiente aberto rompem com o ambiente de trabalho puramente cognitivo, onde estão rodeados de cadeiras, carteiras, lousas e livros. O famoso "rola a bola" é destacado pelo autor como muito evidente no ambiente escolar e contribuir com a denotação de aula livre e divertimento à $\mathrm{EF}$, pelo fato de não haver conteúdo dirigido e se realizar atividades de livre escolha sem orientação ou significância.

É importante ressaltar o destaque de Nista-Piccolo e Moreira (2012) de que a EF é a disciplina do componente curricular que mais se aproxima do contato com o corpo, diferente das demais em que aluno possui sua dedicação centrada na cognição. Sendo assim, o aluno passa grande parte do tempo em sala, na carteira, focado em atividades, e quando vai para a aula de EF, experimenta um novo ambiente e um movimentar-se que o desata do imobilismo das carteiras de sala de aula.

De modo similar e aproximando sobre o que os autores afirmam em relação à diferença entre a EF e as demais disciplinas em seu modo de execução, aplicabilidade e espaço em que ocorre, o aluno S6 em sua fala não usa a expressão "tempo livre", porém, fala exatamente essa questão ao citar: “... porque a gente fica o dia todo dentro na sala sentado, no recreio é só meia hora de recreio, aí educação física a gente aproveita...”. Também o aluno S10 ao expressar o que a EF significa para ele, afirma: “Tipo, é um momento, assim, que é mais livre, eu posso movimentar, eu posso fazer as coisas que eu gosto, que é, no caso, o esporte...”. S8 com a opinião similar sobre a importância da EF, diz que para ela é uma forma de descanso, observe: "Para mim é como se fosse um descanso das aulas, tipo, não ficar muito na sala de aula, um jeito de distrair também". Presume-se que para eles a EF sendo na quadra e estando fora da sala de aula configura-se um espaço em que gastam suas energias, ou mesmo 
descansam sua mente e o corpo, pois podem escolher o que vão fazer (como muitos afirmaram).

Semelhante à constatação feita na entrevista com os alunos, Cavalieri (2012) em um estudo com o ensino médio ressalta esse ponto em que os alunos encaram a EF como uma hora de lazer, em que não estarão dentro da sala de aula e, em meio a isso, não há preocupação dos docentes em motivar esse aluno por meio de aulas planejadas, tudo se limita ao jogar futebol ou o que for da vontade deles.

Refletir sobre esse tema nos leva a outros questionamentos, dentre eles como a EF está sendo apresentada para esses alunos, desde muito cedo inclusive, para que eles tenham essa conclusão. A representatividade da prática de exercícios físicos para os alunos depende de muitos fatores, principalmente seu contexto social e cultural, contudo, devido à importância da disciplina de EF e sendo parte do currículo escolar, nota-se essa marginalização da mesma (atribuindo a ela o plano secundário em importância) como reflexão para o conceito de seus beneficiários (os alunos). Se observarmos a EF como uma disciplina que pertence também a um campo, do ensino/educação, ela não caracteriza, segundo Bourdieu (1983), legitimidade dentro desse campo como as demais disciplinas (pois ela é apenas para jogar bola ou brincar). Ideia essa evidentemente ortodoxa que precisa ser rompida por meio de reflexões e conscientização.

Sobre a representatividade da EF para esses alunos, além do "tempo livre" ou "descanso", os demais destacaram muito a questão do esporte, isto é, a prática ou aprendizagem de uma modalidade esportiva como função principal das aulas. Tal tema será abordado no próximo item.

\subsubsection{A prática esportiva}

Foi notório que muitos dos entrevistados citaram o esporte como sua principal referência para significar as aulas de EF quando expõe a representatividade da disciplina em suas vidas durante as entrevistas.

Os alunos S2 e S5, ambos com preferências opostas em relação às atividades esportivas, pois uma não gosta de competições e outro gosta, entendem as aulas como um espaço de aprendizado sobre os esportes e prática de uma atividade física. No depoimento de S2 sobre as aulas ela diz: "Para mim tinha que representar para você praticar algum tipo de esporte assim, para você fazer atividade física". Para S5, as aulas estão ligadas à prática esportiva, 
quando cita: "Representa praticar esportes, tipo, conhecer vários esportes, não um só, e aprender mais sobre a educação física”. A aluna S4 destaca que a pausa a qual se refere é o que acontece atualmente nas suas aulas, porém, sua opinião está de acordo com a dos colegas ao afirmar que as aulas de EF deveriam: "aprender um novo esporte, a gente, sei lá, fazendo, se movimentando". S9 relata "[...] eu posso fazer as coisas que eu gosto, que é, no caso, o esporte, então o professor deixa, assim, escolher o esporte que a gente quer, então tem vezes que a gente joga basquete, a gente joga vôlei [...].

Também reforçam esses depoimentos os alunos: S7 e S10 ao relatarem respectivamente: "Eu acho que é uma aula que você tem que jogos esportivos".; "Representa um esporte". Além deles S3, S6 e S9 faz a menção ao esporte como a principal prática da aula, citando modalidades como basquete, voleibol e futebol. O esporte se faz muito presente como principal conteúdo programático das aulas de EF desde muito cedo e isso é de grande influência para essa opinião dos entrevistados.

É conveniente afirmar que a significância associada ao esporte remete à EF com sua tradição em aulas práticas esportivas, como ressalta Guedes $(1999$, p.10) “a maior ênfase nas aulas de educação física venha a ser os esportes competitivos, iniciando logo na 5 a série, senão mais precocemente, e permanecendo durante todo o período de escolarização". Cabe ressaltar o que Soares (2007) afirma sobre as influências dos métodos ginásticos europeus na cultura brasileira, em especial a ginástica alemã, a qual trouxe as práticas esportivas e regras que predominaram fortemente em meados de 1970 e seus vestígios são perceptíveis nesses resultados.

Em vista disso, abordagens como a desenvolvimentista predominam no cenário das aulas de EF. Os professores seguem a linha de Tani et al. (1988) e realizam trabalho voltado para desenvolver e aprimorar habilidades motoras, aperfeiçoamento da aptidão física e expectativas padronizadas para sua idade e série. Esses profissionais trazem consigo capitais, "habitus" e cultura de aprendizagem voltada ao ensino de habilidades motoras (e também esportivizadas) do que a concepções mais críticas e isso se deve ao histórico e contexto ao qual se inserem e se propaga ao longo das gerações.

Contudo, muito mais do que um intervalo ou aprendizado esportivo como dito pelos alunos, a EF representa um conjunto gigantesco de atividades que visam, em especial para o ciclo II do Ensino Fundamental, ao aprimoramento motor, à percepção da postura do próprio corpo e a estudar as características dos movimentos de sua coletividade, além de atividades rítmicas e expressivas que combinem marcação de ritmo e coordenação (BRASIL, PCNEDUCAÇÃO FÍSICA, 1997). 
Betti e Liz (2003) realizaram um estudo com alunas do Ensino Fundamental a respeito das aulas de EF, e afirmam em suas conclusões que elas associam a disciplina fortemente ao esporte e também diferenciam a satisfação propiciada pelas aulas à importância de outras matérias como Português e Matemática. Confirmam, assim, o que S2, S5 e S4 associam à sua representatividade da EF: conhecimento e aprendizado de esportes.

Para alguns alunos foi questionado o que eles mais gostam ou menos gostam da aula, para outros sobre o esporte preferido, essa diferenciação ocorreu em vista do desenrolar da entrevista (pela própria fala do entrevistado) e o direcionamento que ela foi tomando, contudo, a questão esportiva apareceu em todas elas. Mesmo aqueles alunos os quais o questionamento não se referia a uma modalidade esportiva, a resposta tomou esse rumo. Como se pode ver, S3, S10 e S11 ao responder o que menos gostam da aula destacam respectivamente os seguintes esportes: basquete, futebol e vôlei. S8 diz que sempre gosta de tentar praticar algo (mesmo que não haja direcionamento) e o que ela mais aprecia é o vôlei.

Vale lembrar na abordagem desse tema e em virtude da aproximação que os alunos fazem das aulas de EF às práticas esportivas, que predominam as mais conhecidas e difundidas pela mídia, como: futebol e voleibol. O basquete é pouco citado, e não vimos alunos ressaltarem outras modalidades como handebol ou mesmo individuais como atletismo e lutas previstos nos PCNs. Para confirmar esse fato, em estudos que mostram conteúdos mais aplicados na EF, Nobre et. al. (2009) elucida em um estudo feito em Juazeiro do Norte (CE) o futsal como o maior percentual de aplicação, seguido pelo voleibol e handebol.

Para reforçar o que a pesquisa vem apresentando, vemos que o esporte é o veículo mais utilizado para difundir o movimento corporal no ambiente escolar. Ele é colocado como centro das aulas de EF, com prioridade sobre outro conteúdo e práticas em função dele (OLIVEIRA, 2001). Além disso, apenas algumas modalidades, dentre elas o futebol, basquetebol e voleibol fazem parte do conteúdo da EF. Raramente nota-se a presença de danças, atletismo, ginástica e outros. (BETTI, 1999). Souza e Pagani (2012) confirmam em seus estudos que o esporte como conteúdo mais presente em $71 \%$ das respostas dos alunos e percebe-se que a "bola" se tornou início, meio e fim para as aulas. Farias et al. (2017) também trazem relatos de alunos entrevistados, o esporte como condutor principal da EF escolar.

Os professores lecionam "aulas de esporte" não aulas de EF, principalmente quando esses já vivenciaram contextos esportivos (BETTI, 1999). É oportuno frisar que os currículos de cursos (de ensino superior) de EF, não todos evidentemente, destinam considerável carga horária para o ensino do esporte, o que contribui para a aquisição de conhecimento e futura aplicação no ambiente escolar (CAVALIERI, 2012). 
Betti (1999) destaca a tradição que o Brasil possui na esportivização desde a década de 50 e atingiu o auge na década de 70 com o binômio Educação Física/Esportes. Com isso, a cultura do movimento corporal em nosso país tem seu primeiro momento na ginástica e o segundo, e também atual, no esporte (BETTI, 1999). A EF e o ato de ensinar esporte fizeramse sinônimos e outros conteúdos como ginástica, lutas e atletismo ficam à margem e dão lugar ao futsal, basquetebol, handebol e voleibol (PIMENTA; HONORATO, 2010).

Sendo assim, o tema abre destaque para um ponto paralelo e importante nesta significação que é a formação docente. Existe a necessidade de conexão entre as instituições de formação superior (seus aprendizados) e a prática do cotidiano das aulas, bem como manter este docente em continuada formação, ou seja, atualizado sobre formas de realizar seu trabalho de maneira satisfatória.

Quando há o predomínio de um conteúdo, como o esporte, a motivação daqueles que têm menos habilidades apresenta-se de forma extrínseca. O relato de uma aluna aponta: "nas aulas todas eu ficava caminhando, conversando com minhas amigas" (S8), e isso mostra que a aluna não tem motivos inerentes à prática ou algo que a faça apreciar a mesma. Com isso é preciso destacar que os alunos que não se destacam em habilidades esportivas, têm como opção ficar andando pela escola ou ficam sentados nas imediações da quadra (SOUZA; PAGANI, 2012).

Assim como a maioria dos entrevistados neste estudo, um levantamento de Betti (1999) ressalta o ponto de vista dos alunos realmente atribuírem a identificação do significado da disciplina Educação Física com o esporte, a partir do $6^{\circ}$ ano. É preciso acentuar que essa referência ao esporte demonstrada pelos alunos provém de uma tradição aos esportes coletivos que em muitas vezes são aplicados de maneira descontextualizada e não organizada, ocasionando a falta de aprofundamento no conteúdo e conhecimento superficial por parte dos agentes (PEREIRA; SILVA, 2010).

A EF possui vários conteúdos com o objetivo de promover o aluno na cultura corporal do movimento, a questão da aplicabilidade das práticas esportivas em excessivo nas aulas promoveria a exclusão dos menos habilidosos e, assim, geraria o desinteresse pala área (CAVALIERI, 2010). Até mesmo dentro do conteúdo que envolve as modalidades esportivas é possível verificar diversos temas em paralelo para enriquecer a formação do educando.

Como destacam Darido e Souza Junior (2015), algumas questões podem ser trabalhadas por meio da promoção de um painel ou jornal de notícias como: anabolizantes, violência no esporte, lesões, exercícios específicos para melhoria em determinada modalidade, etc. 
Assim como Betti (1999) cita em outra pesquisa que alunos que aprenderam uma ou duas modalidades esportivas afirmam que gostariam de uma diversificação dos conteúdos, e fica mais fácil de citar sua preferência quando há experiência em vários conteúdos.

Souza e Pagani (2012) destacam as opiniões de alunos que demonstram anseios a outras práticas e modificariam suas aulas com dinâmicas, ginásticas e atividades lúdicas. De modo similar, os alunos entrevistados nesse estudo destacam em alguns momentos da entrevista a ânsia por outros conteúdos, inclusive modalidades esportivas, como é o caso de S9 que fala sobre a prática do Judô (modalidade a qual já pratica), S2 fala sobre ginástica de academia e S10 cita que gostaria de conhecer e aprender o Badminton.

A EF é muito mais rica do que se limitar a uma modalidade esportiva ou até mesmo apenas às práticas esportivizadas (BETTI, 1999). Há uma concepção fechada de movimento, quando o "movimentar-se" é reduzido ao ensino e à aprendizagem das formas esportivas de movimento (HILDEBRANDT-STRAMANN, 2003). Sendo assim, faz-se necessário a mudança dessa cultura que está presente em grande parte do ambiente escolar, e confirmada pelos autores citados: Betti e Liz, Souza e Pagani, Pimenta e Honorato e ratificando como prova muitas citações da literatura e também este estudo.

É preciso que as aulas de EF segundo os PCNs da Educação Física (1997), promovam seu real objetivo para com a cultura corporal do movimento, atenda à diversidade, aos interesses dos alunos com ricos conteúdos que tem a oferecer e forme cidadãos críticosreflexivos. A aula de EF deve ser um processo de interação social, no qual o professor e os alunos definem suas situações de ação e, determinam os seus significados, uma aula "aberta" e de movimento (HILDEBRANDT-STRAMANN, 2003). O autor propõe uma aula participativa não só na aplicação, mas na sua construção para romper com o tradicional e significar o aprendizado.

Para transformar essa representatividade apresentada pelos alunos com conceitos tão pontuais para com a EF, as abordagens críticas precisam ser compreendidas e favorecer a compreensão de mundo e das atividades de forma crítica e construtiva. Utilizar por exemplo, fundamentos da crítico-superadora para superar desigualdades, da crítico-emancipatória para voltar o olhar crítico aos temas trabalhados, à cultural que considera a realidade do sujeito e outras que ampliarão a ideia sobre a significância da disciplina no cotidiano de todos. $\mathrm{O}$ intuito seria mesclar algumas delas e não o pleno domínio de todas, uma vez que não existe a abordagem "ideal" ou "mais importante", porém a que mais se encaixa no contexto ou uma integração que favoreça à boa formação dos alunos. 
Ao analisar os depoimentos e a literatura levantada sobre essas duas sessões em que se apresenta a representatividade da EF para os alunos, pode-se ter um olhar para os aspectos da teoria da motivação. É perceptível a presença de fatores extrínsecos para a maioria, pois os alunos são impulsionados à aceitação de um valor (RYAN; DECI, 2000), o qual seria a prática esportiva e a EF enquanto uma disciplina que precisam cumprir na grade curricular e se realiza fora da sala de aula (associando ao tempo livre). Além disso, os depoimentos confirmam o que Neto et al. (2010) destacam, ou seja, que muitos alunos perdem a motivação devido à repetição de conteúdos e predomínio de técnicas esportivas (ou mesmo a forma como eles são aplicados).

Em alguns é possível observar, como S5 e S9, a prática esportiva um fator intrínseco, pois sentem prazer e autodeterminação para continuar a atividade e ambos demonstram gosto pelo conteúdo esportivo ao longo do diálogo, sentem-se impulsionados à prática (TAYLOR; NTOUMANIS, 2007).

Caso alguns entrevistados atribua tal representação da EF em suas vidas, seria em virtude de suas vivências e experiências. Com isso, se faz importante conhecer como são as aulas desses alunos e o que eles pensam sobre a forma como ela acontece e como é ministrada. Com os demais depoimentos foi construído o tema da próxima sessão sobre o ambiente das aulas de EF nesta instituição para o $9^{\circ}$ ano do Ensino Fundamental.

\subsection{O conteúdo da aula: "aula livre", conteúdo dirigido e o papel do professor.}

Durante as entrevistas não foi preciso um questionamento específico para conhecer a realidade das aulas, pois em diversos pontos foi citado pelos alunos a "aula livre", em especial pelos jovens do primeiro grupo, que foram entrevistados antes da mudança de professor. Sobre os alunos que participaram da entrevista no momento em que o novo professor havia assumido a turma, citam as aulas com conteúdos dirigidos.

Pode-se citar em alguns relatos: “[...] o professor não dá mais o que ele dava, ele dava mais queimada, handebol às vezes, mas aí ele não dá mais, aí o pessoal fica mais no celular, fone de ouvido [...]” (S3); “[...] não tem aula especifica de um esporte, eu posso fazer o que eu quero [...]" (S5); "Eu gosto mais desse professor porque ele dá as atividades, o último professor ele geralmente não dava muita atividade [...]" (S6); "Esse professor aí ele dá atividade, eu faço, mas quando era o PX ele não dava atividade [...]” (S8). 
Esses dados foram de dois alunos do primeiro grupo e dois do segundo grupo de entrevistas. O tema se construiu pela ausência ou presença de conteúdo com uma aula dirigida e consequentemente o papel do professor que possui a função de orientador e instigador do conhecimento. O conteúdo se liga a um fator motivacional, pois, a desmotivação por parte dos alunos relaciona-se com o desinteresse pelo conteúdo e abordagem adotados pelos professores para desenvolvimento das aulas (RANGEL-BETTI, 1995).

Para melhor discutir cada ponto e analisar outras opiniões associadas ao conteúdo teremos os subtemas: A aula livre predomina, o conteúdo dirigido e o papel do professor.

\subsubsection{Aula livre predomina}

Os alunos citam a aula livre durante as entrevistas pelo fato de ficarem à vontade nas aulas, poderem escolher o que fazer, ficam caminhando, "mexendo no celular e conversando" (S6), pois o professor não passava atividades.

Nascimento e Garces (2013) corroboram denominando de "aula livre" ou prática de "rola a bola", na qual os alunos realizam um esporte ou atividade qualquer sem objetivo didático, mas para mantê-los ocupados.

Darido e Souza Junior (2015) confirmam o "rola a bola" como bastante representativa no ambiente escolar, o que fomentaria a marginalização da EF perante as demais disciplinas. Porém, essa prática e aplicabilidade parece ter surgido devido às condições de trabalho e a interpretações equivocada dos professores para uma tentativa de autonomia para com os alunos, e que não é defendida por muitos estudiosos e acadêmicos da área.

“Aula livre" ou "Conteúdo livre"? É preciso esclarecer que a prática do "rola a bola" e "aula livre" que traz a literatura está ligada ao aspecto de "conteúdo livre", isto é, um conteúdo de escolha dos próprios educandos, sem a intervenção do docente. Contudo, o que se percebe pela fala dos alunos é que a "aula livre" que ocorre possui uma liberdade além dos conteúdos, na qual se opta inclusive por não praticar atividade alguma.

O conteúdo foi um dos motivos mais citados pelos alunos como algo que faltaria para melhorar as aulas de EF. Os alunos afirmaram que não possuíam conteúdo dirigido, ou seja, durante as aulas eles poderiam escolher a atividade que desejassem praticar, e aqueles que não quisessem praticar, ficariam sentados conversando. Com isso, as aulas de EF são transformadas em um espaço de recreação e lazer (CAVALIERI, 2012) quando não em um espaço social ou dedicados aos artefatos tecnológicos (celulares). O aluno S5 se mostra 
descontente com a falta de conteúdo aplicado pelo professor, e diz que muitos ficam mexendo no celular ao invés de ao menos tentar praticar algo. A partir da pergunta "Tem algum conteúdo que você menos gosta da aula?", o aluno relata:

S5: Não, só às vezes quando o povo não joga futebol nem vôlei e fica no celular. [...] a gente sai da sala às vezes nem tem gente que nem vai para educação física, fica no banheiro ou aqui no pátio, não entra para praticar o esporte, e isso aí tipo dá falta para eles, aí azar deles, mas eles não praticam nada, aí fica as pessoas lá, e é ruim, eu acho que os professores tinham que ir lá buscar [...].

No decorrer dos discursos do primeiro grupo de entrevistados percebe-se que todas as aulas são livres e que há falta de interesse do professor em aplicar alguma atividade ou conteúdo programático. Pode-se confirmar por mais alguns relatos, tais como S1 ao S5: “[...] o professor chega lá e ele não passa nada para a gente, não passa uma queimada, um vôlei [...]" (S1); “[...] é sempre a competição ou uma livre, que na aula livre ninguém faz nada [...]" (S2); "Eu gosto bastante da aula de educação física, mas o professor não dá mais o que ele dava, ele dava mais queimada, handebol às vezes, mas aí ele não dá mais, aí o pessoal fica mais no celular, fone de ouvido [...]” (S3); “[...] não tem aula específica de um esporte, eu posso fazer o que eu quero, então, eu só jogo futebol e vôlei que tem mais ali [...]”(S5).

Em seu discurso a aluna faz um resgate positivo de uma EF já vivenciada por ela e o atual contexto: “[...] a gente já teve aula de educação física que a gente aprendia o esporte, mas hoje não é nada, de vez em quando tentava jogar bola com os meninos só para não ficar à toa, mas é o que mais a gente faz, ficar à toa, assim. " (S4); Ela complementa outra situação que se recorda: "É tudo muito parado, eu gostava antes, quando, assim, antes do sexto ano que o PY ele dava coisa para a gente fazer, jogar jokenpô, vôlei, queimada, mas hoje eu não gosto, porque não tem nada para fazer [...]”.

É possível observar nos depoimentos de S1 e S4 ao considerarem a EF uma espécie de "descanso" (como discutido no primeiro tema) das aulas convencionais de sala, relação direta com os conteúdos desenvolvidos ou até mesmo a falta deles como relatam os alunos. Este conteúdo não dirigido ou "aula livre" confirmado pela aluna S2 é algo que Marchini e Armbrust (2012) destacam ser necessária cautela, pois, quando o professor deixa a turma à vontade para praticar o que desejam, dando uma bola a eles, não há garantia de aprendizado.

Os alunos entrevistados após a troca de professores (S6 ao S11), tiveram alguns discursos diferenciados com relação ao conteúdo. Eles afirmaram que o novo professor aplica algumas atividades, contudo ratificaram a presença ainda de aula livre (há uma "negociação"): “[...] ele chega lá no dia dá aula de vôlei, por exemplo, aí depois ele dá aula livre, aí deixa 
meio tempo [...]" (S6); “[...] o professor passa uma aula normal com atividade dele e uma aula livre mais ou menos [...]" (S7).

Quando é criada a cultura, como esse tipo de aula que os alunos vêm possuindo ao longo dos anos, é difícil reverter o cenário e apropriar os agentes de um novo modo de prática, especialmente para adolescentes. A aula livre faz parte do habitus dos alunos, e aqueles que a aceitam por comodismo ou algum outro motivo corroboram os ortodoxos, enquanto agentes como o novo professor e alunos descontentes (ansiosos por mudanças) que contrapõe o tipo de aula seriam heterodoxos (BORDIEU, 1983).

Os resultados de estudo com objetivo similar, realizado por Nascimento e Garces (2013) com jovens matriculados nos anos finais do ensino fundamental em uma escola estadual do Rio Grande do Sul (RS) também coincidiram. No referido estudo, as autoras elucidam afirmações semelhantes dos seus entrevistados, tais como: "não estamos aprendendo nada só jogamos", “a educação física é sempre a mesma coisa, jogamos o que queremos". (NASCIMENTO, GARCES, 2013, p. 7, 8).

Em virtude do predomínio da aula livre, alguns alunos disseram sentir falta de incentivo a novos esportes, isto é, conhecer novas modalidades. Um exemplo é o depoimento de S1 ao ser questionado sobre os conteúdos das aulas (se considera legais/favoráveis):

S1: Não são porque o professor ele chega lá e não passa nada para a gente, não passa um esporte, não incentiva a gente praticar algum esporte, então ele deixa a gente lá e... como aquela pausa que eu havia falado, e é esse ponto que eu mais assim eu fico com receio, porque o pessoal não pratica esportes e isso afeta a pessoa, a vida dela, a saúde dela.

O mesmo aluno afirma que nem sempre participa das aulas: "Meio que às vezes eu fico com pessoal e jogo, pratico algum esporte, e às vezes eu fico com as pessoas que ficam só sentadas jogando alguma coisa” (S1).

Percebe-se que, o aluno ressalta que pratica as aulas de acordo com sua vontade e, a partir da pergunta que se referia aos conteúdos, o aluno faz uma crítica ao tipo de aula (livre), remete à questão do significado que ele atribui à EF (abordado em tema anterior como "pausa" ou tempo livre) e ainda se diz preocupado em relação ao aprendizado esportivo e a questão da saúde (abordada posteriormente).

Foi pertinente durante as entrevistas realizar um resgate histórico com os alunos sobre as aulas de EF que tinham quando crianças, desde o primeiro ano do Ensino Fundamental até os dias atuais, e todos afirmaram que os conteúdos dos anos iniciais eram mais diversificados, havia outras práticas e mais aprendizado, menos competição - como ressalta a aluna S2 - e 
muitos frisam os jogos e brincadeiras, recordam a diversão e sentem falta de algo semelhante. Esse modelo de aula predomina nos anos iniciais e é extremamente favorável para a motivação da criança, pois desperta comportamentos exploratórios, curiosidade e diversão, os quais não são associados apenas à recompensa e caracterizam-se móvitos intrínsecos (RYAN; DECI, 2000).

É pertinente destacar ainda que, nos anos iniciais do Ensino Fundamental, há integração maior entre o(a) professor(a) (pedagogo) com o professor de EF, e isso favorece o desenvolvimento de atividades interdisciplinares com os alunos, enquanto nos anos finais os alunos possuem vários docentes e essa integração (entre os professores especialistas, inclusive EF) se distancia.

Constatou-se, assim, que houve uma ruptura do estilo de aula de EF em diferentes etapas do Ensino Fundamental. Observa-se isso no depoimento dos seguintes alunos:

S1: [...] era boa, porque tinha várias atividades em grupo e, por exemplo, [...] tinha uma atividade que um tinha que correr atrás do outro, que o pessoal gostava bastante naquela época, e que hoje se perdeu bastante.

S4: [...] eu lembro do professor do primeiro ano que ele fazia, igual essa professora que está aí hoje, ele dava um monte de coisas para a gente fazer, ficar correndo, brincar de pega-pega, não sei, aí a partir do quinto veio um professor chamado $\mathrm{MX}$, não sei, que foi ele que ensinou a gente a jogar handebol não foi handebol, $[\ldots]$ ele ensinou a gente a jogar o Rugby, aí eu acho que vai se perdendo por conta, foi o que eu falei, do professor mesmo [...]

S10: Ah, bem diferentes, já fazia, corria, era uma coisa bem diferente. [...] Falta de conteúdo, ficou parado, aí as pessoas viram que preferiam ficar parado do que ficar fazendo alguma coisa.

S11: Teve um tempo que todo mundo participava, primeiro, segundo, até o quinto ano todo mundo participava, no sexto também, mas depois do sétimo o PX não passava.

Com tais depoimentos percebe-se que o predomínio da aula livre ou do "rola a bola" se faz nas aulas ao longo de alguns anos para essa turma e pelos destaques obtidos nos dados os alunos tendem a criticar a postura e atribui responsabilidade principal ao professor.

Segundo Darido e Souza Junior (2015), a prática da aula livre desconsidera a importância dos procedimentos pedagógicos do docente e é extremamente condenável.

Apesar de aula livre ser encarada como um aspecto negativo é válido ressaltar que uma aluna, pelo fato de não gostar de competição, frisou que este momento livre é o que ela mais gosta na $\mathrm{EF}$, quando questionada sobre o que mais aprecia em aula:

S2: Parte de aula livre, porque aí você não é obrigado a fazer aquilo, que se você estiver cansado ou com alguma dor é obrigatório fazer a 
aula, não é obrigatório ficar ouvindo nhem, nhem, nhem de gente, aí você pode jogar o que você quiser [...].

A atividade competitiva não é do agrado da entrevistada, e isso com certeza influenciou o seu apreço por uma aula "não orientada" a um esporte de competição, contudo fundamentado nos dados analisados pode-se constatar que as atividades mais realizadas pelos alunos, mesmo em aulas não dirigidas, são competitivas e esportivas como: futebol, voleibol e alguns citaram o basquetebol.

Por meio de depoimentos resgatados eles frisam sempre as duas modalidades: “[...] eu só jogo futebol e vôlei que tem mais ali [...]" (S5); "Jogava futebol ou vôlei” (S3); "De vez em quando eu tento jogar futebol com os meninos, mas não dá muito certo, aí eu parto para o vôlei, eu fico tentando fazer alguma coisa [...]” (S4); “Às vezes eu chego a praticar futebol e basquete" (S1). Com isso, há uma cultura e predomínio do esporte de competição em meio aos alunos, e esse fato se faz importante para analisar o próximo subtema.

Essa dominação de alguns esportes é comprovada em um estudo de Nobre et al. (2009) sobre conteúdos aplicados na EF em uma cidade do Ceará (CE), ao entrevistarem professores constataram que no bloco esporte as modalidades mais aplicadas pelos professores foram o futebol em primeiro lugar seguidos do voleibol e handebol.

O predomínio da "aula livre” traz um cenário que se observa algo que Kobal (1996) e Rocha (2009) apontam em seus estudos: alguns alunos irão praticar qualquer atividade proposta (neste caso, orientadas ou não pelo professor), outros não querem participar, alguns criam pretextos e a aula não atinge os objetivos da disciplina. Tais alunos que afirmam praticar algo, mesmo em aulas livres são possíveis perceber o gosto inerente pela atividade, isto é, a motivação intrínseca (RYAN; DECI, 2000) e também pela teoria da realização em que o aluno pratica pelas tendências, vivências e emoções que carrega (WEINBERG; GOULD, 2001). Esse motivo caracteriza-se, portanto, na atividade e não na aula às quais observam que deveria ser orientada e dirigida.

Os demais alunos não apresentam motivação elevada e anseiam por aulas diferenciadas. No relato da aluna S2, por exemplo, existe grande rejeição à competição que provavelmente provém de situações de fracasso, a qual na teoria da atribuição de Weinberg e Gould (2001) diz que situações de fracasso promoverão maior ou menor motivação na atividade, e neste caso foi menor. Kobal (1996) diz inclusive que o jogo cooperativo tende a proporcionar maiores fatores intrínsecos em relação aos competitivos e neste caso o predomínio do competitivo reduziu tais fatores na aluna. 
É importante destacar que a "aula livre" é algo que deve ser revisto e refletido pelos docentes da disciplina, uma vez que apesar da nomenclatura o que se percebe é uma ausência de aula e um espaço de livre escolha para qualquer atividade. Além disso, cabe aos coordenadores pedagógicos também uma postura para realizar um trabalho integrado com esses professores e alunos, uma vez que há um vasto conteúdo para ser trabalhado neste tempo e espaço em que se intitulou de "rola a bola".

Convém ressaltar ainda que assim como os entrevistados neste estudo, Nascimento e Garces (2013) destacam que os alunos, na grande maioria, gostam das aulas de EF. Porém, clamam por objetivos mais claros nas aulas, valorizam os momentos de prática e com a participação de todos, anseiam conhecimentos aprofundados sobre os esportes, atividades diversificadas. Os alunos compreendem que a aula vai além do "jogar bola" e que deveriam ser melhores. Contudo, a prática pode ser melhorada quando todos os agentes envolvidos, alunos e professores, estão dispostos a fazer a diferença.

Na próxima sessão, abordaremos alguns conteúdos dirigidos que foram citados pelos entrevistados, fato esse que aconteceu após a mudança de professor. Cabe também frisar a preferência de atividades que predomina nas aulas durante o próximo tópico.

\subsubsection{O conteúdo dirigido}

Os dados mostram que a partir do momento que houve a troca de professor, alguns depoimentos em relação ao conteúdo mudaram em comparação aos alunos já entrevistados. Pode-se observar nos depoimentos:

S6: Esse novo professor ele dá um conteúdo direcionado, sem um motivo, eu digo assim entre aspas, porque ele dá, por exemplo, ele chega lá no dia dá aula de vôlei [...].

S7: [...] o professor passa uma aula normal com atividade dele e uma aula livre mais ou menos [...].

S8: Tem conteúdo.

S9: O professor ele passa várias coisas durante a semana, mas, assim, o que mais passa ultimamente é o basquete [...].

S10: [...] agora ele passa bastante, a gente até assim, fica achando que é diferente porque a gente não tinha o costume de fazer, agora a gente faz, ele gosta muito de passar bastante vôlei que eu gosto bastante [...].

S11: Ele passa duas aulas de quarta que tem esportes e na de quinta é aula livre.

Mesmo com a presença da aula livre em alguns momentos, há atividade aplicada pelo professor, isto é, aula dirigida. Os alunos destacam que grande parte dos conteúdos ensinados 
nas aulas são os esportes e seus fundamentos (geralmente os de competição). As práticas que predominam pelos que praticam algo nas aulas são os esportes, na maioria das vezes, como: futebol, voleibol, basquete e jogos como "queimada". "Normalmente quando o professor passa queimada eu gosto mais" (S7).

Vago (1999) diz ser preocupante a substituição do caráter amplo e educativo da EF no âmbito escolar pela intervenção seletiva e especializada do treinamento esportivo e predomínio do esporte nas aulas. Prática essa que tende a caracterizar o privilégio pela competição, habilidade e resultados, não concordando que esses princípios se sobressaiam sobre a EF como um todo.

Ainda que o conteúdo seja direcionado, o esporte (como já citado em sessão anterior) tem sido o veículo mais utilizado nas aulas de EF, com as modalidades mais conhecidas e grande parte das atividades, como jogos, corridas e outros são transformados em prédesportivos (BETTI, 1999). Contudo, o problema não é específico o conteúdo esporte, mas como ele é abordado e ensinado, sendo que Oliveira (2001) defende a reinvenção do esporte na escola com elementos que resgate sua ludicidade e vivência de sucesso a todos. Em vista disso, será que essa aula dirigida analisada nos depoimentos dos estudantes, e as citações dos autores têm contexto e significado para esses alunos? Contribuem para a motivação?

Cada aluno traz consigo habitus e capitais diferenciados de acordo com suas experiências e contextos (BOURDIEU, 1983), sendo assim, a maneira que ele atribuirá significado ou se sentirá motivado para tal prática não é algo que se possa generalizar. Fato é que uma aula de esporte ou atividade recreativa deve gerar a apreciação e a motivação do aluno, e muitos dos alunos que aqui citaram o conteúdo após a mudança de professor demonstraram esse sentimento. $\mathrm{O}$ simples fato de não ficarem parados despertaram $\mathrm{o}$ interesse. Contudo, foi identificado que uma aluna (S2) não aprecia a parte competitiva e se identifica com outro tipo de atividade que é pouco explorada na EF escolar e nessas aulas em específico dos entrevistados não se faz presente, como: ginástica, saltos, corridas, danças, etc.

Darido (2004) reforça que a EF precisa introduzir e integrar o aluno na cultura corporal para que ele possa reproduzi-la e transformá-la. A EF por meio dos gestos e práticas corporais produzirá e reproduzirá a cultura. Contudo, para atender à diversidade social é preciso romper com o currículo elitista, excludente e classificatório, adotar a cultura corporal como objeto de estudos e desenvolver currículo multicultural (NEIRA, 2011). De modo similar não só currículo, mas as aulas desenvolvidas devem refleti-lo, para que não se configure algo na teoria e se aplique uma prática contraditória. 
Assim, o conteúdo predominante gera as respostas sobre representatividade da disciplina, vista em sessão anterior, quando os alunos respondem que a disciplina representa a vivência e o aprendizado de modalidades esportivas.

Em uma aula dirigida é preciso apresentar significado à atividade (seja ela esportiva) ou não. É preciso que os conteúdos reflitam contextos e a realidade da juventude e da cultura brasileira, para que outras habilidades, não só as esportivas, sejam exploradas, pois o contexto educacional visa formar cidadãos (CAVALIERI, 2012).

Planejar e conhecer as necessidades dos alunos é ideal para torná-lo elemento central dos conteúdos e da escola no processo de ensino, para tanto, é preciso entender suas necessidades e o contexto em que estão inseridos (NASCIMENTO; GARCES, 2013). Todavia, de acordo com depoimento de muitos alunos sobre as aulas de EF vivenciadas na escola do estudo, o planejamento e o aluno como fator importante para aquisição da cultura do movimento não parece presente em alguns casos ou períodos. Mesmo sendo uma aula aplicada, em que o professor orienta e explica (como afirmaram alguns alunos) é preciso compreender como fazer o esporte que valorize a cultura do movimento e o aluno possa refletir criticamente sobre ele e modificá-lo (OLIVEIRA, 2001).

É valido ressaltar que os conteúdos repetitivos ao longo dos anos, além de ser um fator que interfere na motivação do aluno, não contribuem para os objetivos mais amplos da disciplina em construir conhecimentos e questionamentos (TENORIO; SILVA, 2013). E, para corroborar essa discussão, existem algumas colocações dos entrevistados na qual observa-se o aceite do "conteúdo" ou da "aula livre" sem questionar ou sem uma perspectiva de mudança. Ao serem questionados se falta algo na aula de EF, eles relatam: "Eu acho que não [...] menos futebol [risos] (S7); "Não, tá tudo certo" (S3).

Por mais que os dados mostrem a indignação de alguns, reclamação de outros, existe também o conformismo. Os alunos referidos anteriormente (S3 e S7), por exemplo, mesmo afirmando em seus relatos a apreciação pela disciplina e considerando-a importante, é necessário aprofundar e significar tal importância, pois o cidadão crítico-reflexivo é formado não na passividade e conformidade, mas no questionamento e na participação, com parâmetros para avaliar a aula.

Mesmo que os dados apresentassem um consentimento de todos os entrevistados de uma aula extremamente satisfatória de EF, sempre existe algo a melhorar, o aluno constrói seu conhecimento a partir de suas experiências acadêmicas e de vida, e todo conhecimento por ele precisa ser refletido e questionado. 
Fato é que o conteúdo dirigido se fez presente com a figura do novo professor, como apresentam os dados analisados a partir de S6 ao S11. Pode-se constatar que o conteúdo dirigido é descontextualizado, isto é, reproduzido à deriva, sem apresentar significância e propósito para o cotidiano, perpetua-se uma cultura derivada do histórico tecnicista da EF e ressalta potencialização para os mais habilidosos.

Contudo, como o ambiente e o contexto possuem grande influência na motivação, para esses alunos que vinham de uma realidade de "aulas livres" ou "rola a bola", configurou-se um quadro de melhoria para as aulas. E isso pode ser constado como na fala de S7: "Eu acho que agora está melhor. [...] Porque o PX não passava atividade quase”. Além disso, esse conteúdo dirigido, mesmo que fora de um contexto planejado e integrado foi motivador para alguns, como destaca S10: “[...] a gente não tinha nada, não tinha nem o incentivo do professor, nem o incentivo da sala, e a gente que é jovem sem o incentivo [...]", sem completar sua fala, é possível interpretar que na concepção da aluna as pessoas caíram no comodismo e agora com o novo professor as aulas melhoraram um pouco.

Com base nos dados analisados, é importante colocar que ao serem questionados sobre algum esporte favorito, as respostas foram basicamente: futebol e voleibol, isto é, modalidades que eles aprenderam nas aulas e as mais difundidas na mídia ou porque não experimentaram outras. Apenas um aluno destacou o judô, pois pratica a modalidade em caráter extracurricular. Cabe ressaltar também, que alguns destacaram a vontade de conhecer/praticar novas modalidades, como handebol, badminton e atividades como dança e ginástica, contudo, outros afirmaram "não saber".

Em vista do que foi apresentado e discutido com a literatura, após a mudança do professor os alunos citaram que ele aplica atividades, e que esse aspecto foi positivo, pois, se antes não havia aula dirigida eles puderam se movimentar e se divertir durante a aula. Percebe-se que os alunos entendem por conteúdo aquilo que o professor os orienta a praticar, sendo a maioria deles um jogo competitivo ou esporte. É um cenário que necessita de análise mais aprofundada e discussões para se propor maneiras engajadas de construir um currículo e uma aula para cumprir os objetivos da EF de formar cidadãos críticos e conscientes à prática do exercício.

Para essa sala em específico, observou-se resultados satisfatórios na iniciativa do professor em romper com o costume da aula livre para uma prática direcionada. Assim, a figura do professor é um fator chave para incentivar e motivar os alunos para as aulas e um pouco sobre o papel desse agente será discutido na próxima sessão como subtema. 


\subsubsection{O papel do professor}

É válido ressaltar que o professor é o agente do campo educacional que orienta o aluno na busca pelo conhecimento, empenha-se em guiá-lo para os melhores caminhos, facilita e fomenta o aprendizado a partir de reflexões e questionamentos. Ele orienta sua prática repleta de significados no meio escolar, configurando-se um dos atores na ação dos saberes (CAMPOS, et al. 2015). Este seria o modelo ideal do papel docente, contudo a realidade revelou outro cenário na escola estudada.

Os dados apresentaram dois papéis distintos referentes ao professor: o primeiro àquele docente que deixa a sala livre para a escolha da aula e é classificado pela maioria como não incentivador da prática; em contrapartida o professor que o substituiu o primeiro é aquele que aplica atividades e permite também um momento "livre", contudo plantou em alguns alunos um novo ânimo para a prática.

Sendo assim, durante as entrevistas o tema conteúdo esteve fortemente atrelado à figura do professor, sendo seu papel visto como incentivador. Na comparação dessas duas citações dos alunos é possível perceber tal fato: “[...] alguns professores não incentivaram, é o que eu falei, a gente ficou muito tempo parado, então a gente não teve esse incentivo.” (S10); “[...] a gente não tem mais incentivo, por exemplo, no quinto ano, que a gente tinha que ir lá e praticar e praticava tudo". (S1). Os alunos destacam a falta de orientação do professor e da aplicabilidade de uma aula diversificada e proveitosa, uma vez que “[...] o professor não dá mais o que ele dava [...]" (S3), gera comodismo e possivelmente desmotivação aos alunos.

A exemplo de desmotivação, a aluna S2 foi enfática ao afirmar em seu depoimento não se sentir motivada para as aulas e explica a razão: "Não, não tenho nenhuma motivação, porque eles não estão nem aí praticamente, o PX só deixa a gente ali fazendo nada [...]”. A aluna, portanto, aponta o fato de estar abandonada em quadra, e quando se pratica algo é sempre o que ela não aprecia, jogos competitivos: “ [...] aqui é sempre a competição ou uma livre, que na aula livre ninguém faz nada, mas quando passa alguns jogos é sempre competitivo" (S2). Sendo assim, não há mediação por parte do professor.

S4 diz que gostaria de ter a "[...] verdadeira aula de EF [...], fazer alguma coisa não ficar à toa $[\ldots]$ gostava de antes quando me movimentava, corria [...]" e hoje isso se perdeu pala maneira que o (até então) professor conduzia a aula, na qual os alunos ficavam caminhando e conversando pela quadra, mexendo no celular e jogando cartas. Tal postura conduz a pensamentos como de S8 ao afirmar que faltava no professor, "vontade de dar aula [...] só ficava sentado". Para esse efeito, “o professor de EF que se acomoda e age desta forma 
acaba por não saber justificar seu papel na escola e sua importância para a formação dos alunos" (NASCIMENTO; GARCES, 2013, p. 3). Todavia, é preciso ressaltar que a prática de qualquer professor por mais que seja questionável é preciso ser analisada, observar o contexto e a formação da qual ele faz (e fez) parte.

Em um estudo com professores de EF do ensino fundamental (em escola pública) Campos et al. (2015, p. 4) destacam um dos problemas e circunstância em relação ao docente e que refletia no desenvolvimento das aulas: "a professora não estava muito motivada ao aplicar os conteúdos, ela explicou que estava com problemas de saúde e aguardava a sua aposentadoria o que levava as aulas não terem um planejamento pedagógico adequado para a realidade em que vivia a escola”. Semelhante ao estudo tem-se a situação do professor regente da disciplina envolvida nesta pesquisa, com diversas citações sobre a questão da aula livre, um dos alunos ao ser questionado sobre qual fator decisivo para mudar o tipo de aula e ser algo mais participativo, destacou:

Assim, eu acho que o professor [...] porque o PX ele está para aposentar, então ele não tem aquela energia de um professor mais jovem para ficar dentro de uma quadra, para falar o que está certo ou o que está errado [...] eu acho que, sei lá, a disposição do professor. (S4)

Portanto, existe um fator que gera comodismo em razão da proximidade de sua aposentadoria, mesmo não sendo motivo para não possuir planejamento e aula diversificada para seus alunos, pode haver motivos de saúde envolvidos e outras condições que também desmotivam o docente.

Os autores Campos et al. (2015) apontaram que existem diversos motivos que levam o professor a posturas de descaso com a EF, uma vez que existam materiais e local precário para realização das aulas, e isso também atinge a motivação dos alunos, excessiva jornada de trabalho (em mais de um local) e baixa remuneração, inúmeras responsabilidades pedagógicas, indisciplina dos alunos, dentre outros.

Caso um professor esteja autodeterminado para ensinar uma aula, então ele se empenhará mais para obter a compreensão e retorno de aprendizado dos alunos (ou seja, mais envolvimento). Entretanto, um professor com baixa autodeterminação pode perceber estratégias de apoio à autonomia como exigir muito esforço, enquanto estratégias de controle podem parecer mais fáceis (Reeve, 1998). A relação significativa entre o envolvimento e a autodeterminação e os efeitos de mediadores das percepções de autonomia e competência indicam que professores que fornecem apoio emocional e mostram interesse para com seus alunos podem potencialmente melhorar essa questão de competência e autonomia dos 
mesmos, independentemente do suporte e da estrutura fornecidos (TAYLOR; NTOUMANIS, 2007).

O estudo não objetivou investigar a motivação do professor, mas dos alunos, portanto, não houve diálogo com nenhum docente da escola e o que se tem aqui são depoimentos exclusivos dos alunos o qual condiz com estudos já realizados na literatura.

A motivação do docente é uma área que, sem dúvida, mereceria estudos mais aprofundados e investigações. Porém, é preciso destacar que não se pode condenar o professor pela postura ou atitudes, e sim promover reflexão e apontar possíveis alternativas. Nos depoimentos os alunos destacam um professor desmotivado que promove uma aula não motivadora, contudo, o relacionamento entre eles é bom.

É preciso frisar aqui que um fator importante é a diferença entre os professores. O professor substituto que foi elogiado pelos alunos devido à aplicação de conteúdos dirigidos possui formação em um contexto mais recente e menor tempo de profissão, sendo podem ser fatores que alteram sua disposição e motivação. É válido ressaltar que a idade não é um fator determinante e não se pode generalizar, pois há professores jovens que apresentam uma postura acomodada e outros que mesmo no encerramento da carreira ainda demonstram muita disposição e motivação para desenvolver as aulas. Contudo, neste estudo o fator idade se ressaltou devido aos depoimentos de alunos e nos estudos de Campos et al. (2015) pelo próprio depoimento do docente.

A postura do professor que substituiu o regente não foi algo inovador, contudo para os alunos fez a diferença. Adotando método tradicional e atividades triviais muitos ressaltaram que a sala passou a ter mais participação nas aulas, porém essa motivação pode se caracterizar como intrínseca ou extrínseca.

Martinelli et al. (2006) destacam que quando se oferece sempre atividades ligadas ao esportes e conteúdos já conhecidos os alunos se sentem saturados, além do que não há uma progressão dos fundamentos ou exercícios aplicados até o seu objetivo final. Contudo a diversidade, sequência pedagógica e significativa das atividades e a possibilidade de participação na escolha pode elevar a motivação (pensando aqui no caráter intrínseco).

É pertinente observar que existe uma visão positiva dos alunos quando o professor trabalha com metodologias diversificadas e abre suas aulas ao diálogo. Intensifica a motivação para suas aulas quando não se isola nas mesmas atividades que privilegia a competição, vitória e os mais habilidosos (SOUZA; PAGANI, 2012).

O primeiro passo, de mudança de comportamento, para retirar os alunos do comodismo foi realizado com as aulas dirigidas, contudo o ideal é que haja essa possibilidade 
de um planejamento construtivo da aula. Existem diversos contextos e "habitus" inseridos em uma sala e isso gera gostos diferenciados e incentivar cerca de 30 alunos ao mesmo tempo não é uma tarefa fácil. Sendo assim, o diálogo entre o professor e o aluno sobre os conteúdos que serão trabalhados e a oferta de escolhas nas atividades, isto é, um planejamento participativo atrelado aos benefícios e significados dos mesmos, naturalmente o índice de desmotivação nas aulas seria reduzido (MARTINELLI, et al., 2006).

Visto como um referencial pelos próprios alunos, e a partir dos dados é possível perceber que eles esperam que o professor assuma verdadeiramente seu papel de orientador e incentivador para significar a prática em suas vidas. Para isso, é preciso que o docente conheça as necessidades dos alunos e o que eles pensam para elaborar um plano de trabalho adequado às necessidades e possibilidades desses jovens, de forma coesa à realidade e ao contexto escolar (NASCIMENTO; GARCES, 2013).

Professores de educação física podem influenciar a autodeterminação dos alunos por meio das estratégias motivacionais que eles usam (TAYLOR; NTOUMANIS, 2007). Mesmo em caso de aulas esportivas, apenas os alunos preferem aprender as técnicas, fundamentos e regras antes de aplicá-los em situação de jogo, contudo professores ignoram esse fato e simplesmente fornecem a bola para que eles joguem, atuando como "zeladores" e transferindo exclusiva responsabilidade do aprendizado aos alunos (RANGEL-BETTI, 1995).

Portanto, o papel do professor precisa de reflexão para melhorar o cenário da EF escolar e contribuir para o aspecto motivacional. Muitos mais que um agente que disponibiliza a bola, um professor "bonzinho" que deixa os alunos em aulas livres, assim como o que aplica conteúdos repetitivos e exclusivos e não trabalha como destaca Darido (2004) a cultura corporal associada às experiências cotidianas, pode estar contribuindo com a desmotivação ao invés de formar um cidadão motivado e reflexivo. Faz-se importante o planejamento participativo e como aponta Mattos e Neira (2000) o docente como mediador e fornecedor de caminhos faça o aluno um ser pensante.

O professor apresentou-se como agente primordial para a motivação dos alunos, em virtude da orientação que proporciona em meio a uma atividade e do significado que atribui a ela. Ele é o mediador que incentiva a autonomia, cooperação, comunicação e eleva a autoestima, aponta o lado positivo dos problemas e procura evitar pensamentos negativos (SAMULSKI, 2002).

Em continuação à análise dos dados, algo muito importante observado entre os entrevistados foi a bagagem esportiva que alguns alunos apresentaram em relação a outros. 
Estes alunos se mostraram grandes apreciadores da EF, participam da prática extracurricular e recebem incentivo familiar no esporte, o qual será o próximo tema abordado.

\subsection{A família e as vivências no esporte.}

Os resultados das entrevistas evidenciam alguns alunos com prática esportiva extracurricular e ainda com influência e apoio familiar. Esses entrevistados apresentam gosto pelas aulas de EF, mesmo quando dizem possuir a "aula livre", gostam de se movimentar e praticar alguma atividade. Seis dos onze afirmaram praticar atividade extra, sendo que apenas um cita ser atividade em academia e os demais são práticas voltadas ao esporte (pois prevalece a cultura e vontade do praticante).

As alunas S3 e S10 afirmam que praticam o voleibol, a primeira possui uma prática voltada ao treinamento, ou seja, para a formação na modalidade e competição, enquanto a outra a pratica por lazer junto com os amigos. O futebol é a modalidade que S5 e S6 afirmam praticar e apreciar muito, sendo que S5 diz treinar desde muito novo e teve sempre a influência e apoio do avô (que também foi jogador). S6 diz praticar a modalidade apenas como lazer com amigos.

O único que pratica um esporte na modalidade individual e que dificilmente o vemos nas aulas de EF é o garoto S9, ele pratica Judô. Disse que o faz desde muito novo, teve a influência do irmão que é competidor e atualmente participa de competições nacionais de sua categoria em disputa de títulos. A única aluna a se diferenciar na prática extracurricular foi S2, que diz gostar muito das atividades na academia, voltada para área de ginástica e dança. Ela diz que não aprecia as práticas competitivas, e o incentivo de praticar exercícios físicos partiu de sua própria vontade.

Conforme destaca Bourdieu (2011) ao falar sobre os capitais que acumulamos durante nossa trajetória de vida transformam o nosso "habitus" e de alguma forma conferem poder e ascensão em determinado campo. Percebe-se, portanto, que alunos como S5 teve seu "habitus" e capitais (cultural e econômico) diferenciados, ao relatar sua trajetória, incentivo e gosto pelo futebol:

“[...] desde de pequenininho eu jogo bola, eu jogava na linha, aí eu comecei a pegar mais gosto, tentar ser jogador, eu quero ser jogador [...] [...] o meu vô, o meu vô me apoia assim, é o mais que me apoia, ele me leva para treinar, me fala o que eu tenho que fazer, que eu tenho que continuar nisso, ele que me apoia mais. [...] ele foi jogador do Comercial daqui" (S5). 
Em virtude disso, é valido supor que a aquisição de capitais faz toda diferença quando se trata de observar a motivação deste aluno para com as aulas de EF.

O aluno S5 corrobora a fala de alguns de seus colegas que as aulas poderiam ser mais diversificadas em esportes e outras atividades, porém que ele gosta e tenta sempre estar jogando algo mesmo nas "aulas livres". Essa diferença em atitude e gosto pela prática do movimento na EF está ligada a esses capitais que o aluno teve acesso e à transformação do seu habitus. Há presença de capitais não apenas culturais (devido ao conhecimento do esporte), mas social (devido ao contato e relacionamento com outros no esporte), capital econômico (uma vez que o aluno frisa praticar a modalidade em uma escola que possui custos) e também o capital simbólico, pois se analisarmos o aluno S5 com os demais em relação à modalidade do futsal este possui vantagens que o configura em ascensão em relação aos demais pelas oportunidades que possui.

Além de S5, o aluno S9 é um dos entrevistados que possui engajamento esportivo. Em sua entrevista observa-se o entusiasmo ao falar sobre a prática de atividades físicas e a paixão pela modalidade que compete, o Judô. Aos 15 anos o aluno possui bolsa na academia de lutas que frequenta para competir, e essa prática o torna uma pessoa competitiva que gosta de fazer sempre o melhor nas atividades físicas e isso inclui as aulas de EF na escola. Ficou evidenciado que a familiarização com o esporte desde cedo trouxe benefícios e motivação para S9, tendo como prova disso quando afirma: “...o judô, assim, me ensinou a ter disciplina, educação, respeitar tudo, então isso é uma coisa que eu vou levar para minha vida inteira...".

De modo similar como S5, o garoto (S9) diz que sua inspiração e incentivo veio do irmão mais velho, também competidor de judô e também que os pais o apoiam cem por cento nessa prática (mesmo eles não tendo sido competidores). $\mathrm{O}$ envolvimento e apoio dos pais é crucial, a fim de servir de modelo para estes jovens e propiciar um ambiente favorável para o engajamento na prática esportiva, uma vez que a falta do apoio pode levar a um abandono da atividade (NUNOMURA; OLIVEIRA, 2014). É importante esta participação familiar, não só em relação à questão de esporte e atividade física, como em relação ao ensino.

Em relação às aulas, S9 fala muito que nem todos participam, que vai muito da atividade que o professor passa, porém, que isso acontece agora, pois antigamente realmente se confirma a existência das "aulas livres". Em seu depoimento cabe destacar este ponto: “...eu não gostava muito porque eu gosto muito de movimentar, fazer atividades novas, tipo, para mim não era muito legal ficar parado". É lícito supor que o fato do jovem ter esse apreço pelo movimento e exercícios físicos se dá pela cultura em que ele está inserido, desde 
pequeno praticando esporte. E, como afirma Bourdieu (1986), faz parte do habitus do aluno, o qual se transforma a cada experiência e também ao seu acúmulo de capitais, aqui frisando até mesmo o capital simbólico (ligado ao esporte e à modalidade do judô).

Dada relevância dessa questão cultural e contexto familiar desses alunos, as entrevistas nos mostram que eles têm a pretensão de seguir a profíssão na EF. Ambos afirmam: “...eu quero fazer faculdade de educação física... porque é uma coisa que eu gosto, que eu gosto de esportes...” (S5); “...como eu gosto de seguir uma profissão que é o caso do professor de educação física, eu gosto o que eu posso aprender eu aprendo para passar para que um dia eu possa repassar isso, então eu gosto muito dessa parte, assim, isso que me deixa motivado a fazer." (S9).

Nesses casos, portanto, o esporte e incentivo familiar como bagagem cultural trazem motivação na área para esses jovens e, consequentemente, os torna participativos em aula. Para eles, existe sentido nas atividades físicas e esportivas e seu aprendizado, sendo denominada na teoria Bourdiesiana de illusio, ou seja, estar envolvido com algo, dar importância a um jogo social, admitir e reconhecer que ele merece ser jogado (OLIVEIRA, 2005).

A literatura apresenta que os pais são responsáveis pelo engajamento dos filhos no meio esportivo pelo incentivo, crenças e também como exemplos de vida. Muitas vezes, a falta de apoio familiar diminui o alto nível de motivação de uma criança que iniciou no esporte, fazendo-a abandonar ou desistir de seus objetivos. Contudo, aqueles que são incentivados por seus pais ou responsáveis permanecem no esporte, sentem-se motivados na atividade que praticam e, em alguns casos, podem chegar ao alto rendimento (NUNOMURA; OLIVEIRA, 2014).

Como S5 e S9 apresentaram uma estrutura em suas entrevistas que nos leva a pensar não só no interesse que esses alunos possuem pela $\mathrm{EF}$, mas em carreiras esportivas que podem emergir. Para esse efeito vale frisar que a estrutura, cultura esportiva, atitudes e outros fatores dos pais (ou familiares) são de grande influência para seus filhos, e também os aspectos hereditários e socioambientais são eixos norteadores para este jovem, tendo a família como microssistema de desenvolvimento e um ambiente propício para o interesse e nascimento de um jovem atleta (VILANI; SAMULSKI, 2002).

É importante destacar que S3 foi a única aluna engajada no voleibol como treinamento extracurricular que não cita a parte familiar como incentivo. Contudo, esse interesse se nasceu dela própria, ou seja, pela própria "illusio" (significância) da agente que vê satisfação e se sente motivada intrinsicamente na prática da modalidade. Nos demais depoimentos da aluna, 
observa-se, portanto, que ela aprecia as aulas, procurando sempre praticar algo (de preferência o vôlei) e que não mudaria nada em sua EF escolar. A aluna S2 está engajada no mundo das academias, e corrobora a jovem S3, dizendo que partiu dela a iniciativa de procurar uma academia e adquiriu apreço pelas atividades lá oferecidas.

Fica evidente que os alunos que participam de práticas extracurriculares e que possuem considerável apoio familiar nutrem maior interesse pelo "movimentar-se", incluindo aqui as aulas de EF. Vale destacar que tal contexto familiar conta diversas vezes com a presença do capital econômico (condição financeira) favorável (BOURDIEU, 1986). Além disso, existe reflexão sobre a prática e motivação inerente à atividade física que se faz presente na fala desses alunos. Conforme citado, cada um possui seu "habitus" e sua cultura de aprendizagem, sendo que segundo Hodkinson, Biesta e James (2007), o indivíduo passa pelo processo de "tornar-se" (becoming) por meio de várias situações de aprendizagem simultâneas e sucessivas. E, assim, ocorre com cada um dos participantes da pesquisa que construiu e constrói sua participação no esporte de maneira distinta bem como possuem famílias distintas. Contudo, a cultura familiar mostra o papel fundamental na apropriação de capitais para esses jovens, bem como para o seu processo de "tornar-se".

Paralelo a este tema, cabe ressaltar nesta sessão o quão importante seria ouvir a opinião desses pais, mães, irmãos e avós incentivadores desses alunos para conhecer seu contexto social e suas opiniões sobre as aulas de EF que esses jovens usufruem.

Como não foi o principal objetivo deste estudo, os próprios alunos ressaltaram que é uma participação considerável e consciente de seus familiares. S5 afirma que seu avô o leva para treinar e incentiva melhorias, disciplina e dedicação; S9 diz que seu pai é bastante exigente e mesmo incentivando-o nas competições e treinos é preciso que não perca atenção nos estudos; e até mesmo a aluna S10 (que pratica voleibol por lazer) diz que sua mãe a incentiva sempre para praticar algo e procura saber do andamento de suas aulas de EF.

A informação sobre a opinião dos pais é de extrema importância para se compreender o contexto familiar que eles vivem. De fato, esses pais consideram importante a prática esportiva para os filhos. E, assim como o estudo de Vianna et. al. (2017), os pais relatam que a prática esportiva extracurricular ajuda no desenvolvimento e comportamento de seus filhos, e frisam que a EF é um espaço e tempo menor com um grupo maior de estudantes e acaba sendo uma atividade mais básica e geral. Os pais afirmam que não tirariam seus filhos da atividade esportiva extracurricular, pois se trata de um complemento para eles.

O mesmo autor, neste estudo feito com os pais sobre atividades extracurriculares voltadas ao esporte mostra um lado preocupante sobre a visão da EF escolar: "os pais 
reconhecem a educação física oferecida pela escola como uma espécie de apoio pedagógico a outros componentes curriculares e não de apropriação das práticas corporais como conteúdo específico da disciplina" (VIANNA et. al., 2017, p. 27). Muitos enxergam como uma brincadeira, uma atividade não tão séria, não percebendo os benefícios para a saúde e a iniciação esportiva promovida pela EF escolar (VIANNA et al., 2017). Não podemos prever a opinião dos pais dos nossos entrevistados, contudo o que esse estudo mostra é que a marginalização da disciplina e a predominância de "aulas livres" estão atingindo a opiniões dos familiares.

No contexto dos entrevistados se observou famílias incentivadoras à prática de esportes, assim como em outros estudos. Porém, no depoimento dos estudantes, apenas uma mãe, procura saber o andamento das aulas, pode-se ver no depoimento quando se refere ao interesse da mãe: "Sim, se interessa, antes era assim, é igual eu falava, eu reclamava bastante para ela que a gente não tinha nada, a gente ficava realmente à toa, mas agora eu falo para ela que o professor é muito bom, ela pergunta sim" (S10). Assim como mostram Nunomura e Oliveira (2014), Vilani e Samulski (2002), a importância do incentivo ao esporte pela família seria essencial para ampliar a participação no esporte e aqui se faz o complemento às aulas de EF (assim como nas demais disciplinas).

Devido a relevância deste tema emergido nas entrevistas, pode-se perceber que a família é um fator motivador, e que tem relação direta com a disposição na prática das aulas de EF.

\subsection{A saúde}

Os dados elucidam diversos depoimentos dos alunos sobre a relação da saúde com as aulas de EF, sendo importante para a qualidade de vida e assim um motivo para exercer a prática. "O que me motiva mais é a saúde mesmo, porque o fato de a obesidade no Brasil ser muito grande eu acho que tentar evitar isso [...]” (S1); “[...] é como se não precisasse de uma academia porque você já está fazendo aquele exercício [...] na escola não, seria de graça e se for ver mais saudável". (S4); "Eu gosto de sempre estar jogando, porque eu acho que isso melhora a minha saúde, aí eu pratico bastante esporte para isso, para a saúde". (S5); "Ah, saúde em primeiro lugar e físico assim, eu acho muito bom tanto para o físico, tanto para a saúde, que ficar parado eu não gosto mesmo, eu gosto bastante de praticar” (S10). Os alunos 
citados destacam suas opiniões ao falarem sobre aspectos que os motiva a fazer uma aula de EF ou buscar realizar o mínimo possível de atividade.

Por parte de alguns, o assunto "saúde" surgiu naturalmente em suas falas, contudo, outros tiveram que ser provocados em um questionamento direta ou indiretamente de acordo com o andamento do diálogo. No depoimento de S2, percebe-se esse exemplo provocativo ao questionar o que ela acha sobre atividade física. Em vista disso, a aluna relata:

$\mathrm{Eu}$ acho que é bem importante, porque atividade física além de ela te deixar com físico ela te deixa com mais saúde, mais disposição, eu acho isso importante para as pessoas, porque se você não fazer, praticar atividade física e sei lá ficar comendo só porcaria aí você vai ter algum problema $[\ldots]$.

A sociedade tem adotado hábitos de vida, seja relacionado à prática de exercícios ou à alimentação, que comprometem sua saúde e tende para o sedentarismo (GUEDES; GUEDES, 1997). Monteiro e Navarro (2011) corroboram ao apresentar dados de obesidade e sobrepeso em alunos do Ensino Fundamental, com 17\% (sendo 11\% meninos e 7\% meninas) em uma avaliação de 257 crianças e adolescentes. Ao observar os dados dos entrevistados identifica-se essa reprodução do sedentarismo citada pelos autores. Por mais que seja dito por elas essa importância da EF para a saúde corporal, percebe-se a existência do conceito, porém, a não apropriação de sua aplicação. Com exceção de S3 (que afirma praticar vôlei), S5 (o futebol) e S9 (é praticante de judô) os demais não possuem o hábito da prática de exercício físico, e afirmam que o celular e até mesmo vídeo games fazem mais presença em seu cotidiano. A aula é reconhecida por muitos como algo legal, prazeroso, alguns afirmam ser aula normal e alguns não mostram tanto apreço e claro que gera reflexos em possuir uma vida fisicamente ativa ou não. Semelhante situação é citada por Souza e Pagani (2012), ou seja, os alunos que não participam das aulas, desmotivam-se e consideram que a Educação Física na escola não tem importância, porém, percebem que a atividade é importante na prevenção de patologias. Assim, percebe-se certa ambiguidade na importância, em saber do benefício que traz a saúde e, por outro lado, a desmotivação por não a praticar.

Alguns enxergam com mais evidência a relação com a disciplina e a oportunidade dessa prática do exercício físico ser efetivada na escola, como o aluno S9: "[...] a gente tem educação física nas primeiras aulas, que é logo sete horas da manhã, então é bom fazer um exercício logo cedo, então isso para mim é um bom benefício, se exercitar logo de manhã, certo, então para mim é bom". Contudo, a aluna S3 ao citar a saúde como fator importante para a atividade física, o entrevistador provoca no sentido de analisar a associação que ela faz com as aulas de EF, e então ela cita: "Eu acho que poderia ajudar (na saúde) também”. Com 
isso, evidencia que a EF na escola e a saúde é algo que parece ser pouco refletido por eles e uma conscientização que ainda está se despertando.

Alguns exemplos que eles fazem dessa associação podemos identificar: na entrevista realizada com S7 ao ser indagado se pratica algum tipo de atividade física ele cita o Xbox, diz que em casa não é de praticar algo e que acha interessante na escola poder fazer os esportes, pois tem a nota e a questão da saúde: “[...] a nota, mas eu acho legal praticar o esporte, em casa é bem menos que eu faço alguma atividade física. [...] Eu acho que para a saúde”. O aluno S6, por exemplo, diz que: “[...] educação física a gente aproveita, o professor ajuda bastante, correr, coisa que eu não faço muito em casa, que eu fico mais no celular [...]”. Um pouco diferente durante o diálogo S8 precisou ser questionada sobre a relação saúde e EF, mas ressaltou: "Acho que ajuda sim na saúde, ajuda", porém a aluna destaca que em seu pensamento a sala se preocupa mais na prática da aula por lazer.

Em alguns pontos é pertinente destacar expressões dos entrevistados que estão indiretamente associadas aos aspectos que envolvem a saúde, como situações emocionais e corporais. No depoimento de S6 ele diz: "Tira um pouco da tensão da aula, aquela coisa de escola muito rígida, diverte a gente, tira aquela tensão" (S6). O aluno afirma então que praticar as atividades físicas nas aulas é importante para aliviar tensões, excessivo esforço de raciocínio, pressões cognitivas por outras atividades, etc. Com um pensamento similar S11 afirma: "Eu gosto de correr um pouco, sair um pouco de ficar parado. [...] Senão eu fico muito parado às vezes dá dor nas pernas”. E também a aluna S4: “[...] eu me desestresso, eu me sinto mais leve, menos cansada, eu me sinto mais leve de todo peso [...]”. Assim, tem-se pontos aqui frisados por eles com relação ao físico, ao psicológico e emocional, todos eles sendo fatores que influenciam em nossa saúde e associados aos benefícios da EF escolar (o potencial da disciplina).

A associação entre saúde e EF se faz presente em virtude de os adolescentes estarem mais propensos aos riscos causados pela obesidade, e esses devem ser considerados como os mais necessitados de assistência. Sendo assim, a disciplina apresenta-se com um conjunto de práticas associadas a um pensamento crítico, que mova os alunos à adoção de um estilo ativo que traga benefícios e qualidade de vida (SEVERINO; SILVA, 2014).

A saúde emergiu como tema natural para alguns, a partir de um assunto eles citavam a aptidão física relacionada à saúde, enquanto outros precisaram ser indagados. As respostas foram importantes para analisar que é uma questão que necessita ser aprofundada no ambiente escolar (no caso dessa instituição) e em especial nas aulas de EF, pois é necessário que os alunos reflitam, formem sua opinião sobre o tema e partam para a ação, sem cair no senso 
comum de apenas manter o discurso que "praticar exercício melhora a saúde". Além disso, se para alguns serve como motivação, aproveitar para intensificar esses motivos e despertar o interesse dos demais.

É importante destacar que experiências positivas na EF e esforços físicos adequados podem influenciar as crianças e jovens a desenvolverem atitudes, habilidades que os auxiliem a adotarem estilos de vida saudáveis quando adultos (TENORIO, TASSITANO; LIMA, 2012; GUEDES; GUEDES, 1997). Corroboram também com essa ideia Oliveira et al., 2005 que um estilo de vida ativo e saudável desde a mais tenra idade pode ser transferida para a vida adulta. Fato este é possível associar ao gosto que S5 e S9 apresentam a respeito da EF. Como observado na sessão anterior, ambos praticam atividades físicas desde muito novos, são praticantes de uma modalidade esportiva, procuram nas aulas participar das atividades e assim, tais fatos geram motivos para adotarem a atividade física como parte de seu cotidiano.

Mediante aos depoimentos dos alunos será que a abordagem da saúde renovada, ou mesmo uma associação à melhoria da qualidade de vida é aplicada nessas aulas de EF? Evidentemente não. Aqueles que citam a saúde não expressam essa consciência em virtude das aulas, mas trazem-na de capitais adquiridos extracurricularmente.

Com isso, é lícito frisar a relevância do professor em conhecer os conteúdos voltados para a saúde, suas variáveis e contextualize-os com a realidade da instituição e o contexto cultural dos alunos (OLIVEIRA et al., 2005). É importante que a saúde faça parte da EF e essa integração esteja presente no PPP da instituição. As aulas precisam configurar-se em um momento não de exclusividade ao esporte ou em detrimento de se objetivar o alcance de metas (embora eles façam parte do processo), mas propiciar também a reflexão entre teoria e prática de atividade física que proporcione bem-estar no presente e no futuro (SEVERINO; SILVA, 2014).

Promover a abordagem da saúde renovada nas aulas não se restringe apenas a ela como proposta pedagógica. O fato de pensar criticamente, participar em conjunto das atividades, tornar o aluno um ser participativo, melhorar a qualidade de vida e desenvolver aspectos cognitivos, afetivos e socioculturais há integração de abordagens como: críticoemancipatória (KUNZ, 2004), sistêmica (BETTI, 1991), construtivista (FREIRE, 1989), cultural (DAOLIO, 1997), desenvolvimentista (TANI et al., 1988). Não priorizar o trabalho isolado de uma abordagem, como observa-se atualmente um viés maior para a desenvolvimentista, mas integrar algumas delas para promoção da qualidade da plena formação do educando. 
Mudar toda uma cultura demanda tempo e trabalho. É preciso agir para propiciar capitais e promover aprendizagens culturais com novas formas de conhecimento que signifiquem a EF em prol da saúde. Romper com o modelo Ortodoxo como afirma Bourdieu (1983) seria preciso para construir uma nova legitimidade no campo, nesse caso da EF, destituir um modelo padronizado e desenvolvimentista para transformar as práticas em benefício da qualidade de vida. Uma prática com significado e benefício para todos como propõe abordagens como a sistêmica e cultural, por exemplo (BETTI, 1991; DAOLIO, 1997).

Para esses alunos, que apreciam e possuem a atividade física como parte de suas vidas, a EF é algo intrinsecamente motivado e a saúde está atrelada a ela (é citada naturalmente).

O sujeito que espera das aulas benefícios à saúde apenas para a melhoria de algum problema (patologia) que possui ou mesmo acredita no benefício por meio do senso comum é caracterizado como extrinsecamente motivado. Neste estudo, aqueles que precisaram ser indagados sobre a saúde tendem a apresentar muito mais motivos extrínsecos para as aulas.

Enfim, a EF como disciplina escolar precisa criar nos alunos o interesse pela prática regular de exercício físico e a busca por um estilo de vida saudável (FERREIRA, 2001). Cabe aos professores de EF promover aulas que levem os educandos a perceberem a importância de incorporar o hábito da atividade física no cotidiano para seu próprio benefício (OLIVEIRA et al., 2005).

Portanto, a função do professor de EF não se resume em transmitir o conteúdo, mas conscientizar o aluno sobre a importância de possuir em seu cotidiano atividades físicas que contribuam à melhoria da qualidade de vida (SEVERINO; SILVA, 2014), e também consequências positivas futuramente.

\section{CONSIDERAÇÕES FINAIS}

O presente estudo analisou a motivação dos alunos do ensino fundamental (concluintes) para as aulas de EF e identificou alunos pouco motivados e que anseiam por algo diferenciado.

O referencial teórico permitiu elucidar transformações que ocorreram e ainda ocorrem na disciplina, ratificar sua obrigatoriedade no currículo e os objetivos que visa para o aluno. Sendo assim, concebem-se atualmente a EF como a área que integra o aluno na cultura corporal, relacionada às linguagens por meio de esportes, jogos, lutas, ginástica e atividades rítmicas. 
A EF é norteada por várias abordagens pedagógicas, que estão à disposição do professor e com potencial para construir seu ambiente de ensino, e todas possuem sua relevância e complementam-se, não sendo definida uma específica e ideal a ser utilizada. Um tema relevante e que aparece, inclusive, como abordagem é a saúde (nas abordagens: saúde renovada), que visa promover um estilo de vida ativo para o aluno, além da autonomia para a prática de exercícios físicos na vida adulta.

As definições e teorias sobre motivação ajudam a compreender como e porque o indivíduo é atraído e movido à ação/atividade e a persistir nesse processo. Assim, foi possível mostrar as diferenças entre um sujeito motivado intrinsecamente (com motivos inerentes à atividade) e extrinsecamente (com motivos externos à prática) aproximando do ambiente educacional, em especial das aulas de EF.

Como foi visto a EF e todo ambiente escolar estão inseridos e dependem de um determinado contexto. O "habitus" dos agentes envolvidos (alunos, professores e outros), bem como os capitais que possuem interferem no desenvolvimento da aula, na motivação e na aquisição de novos conhecimentos que produzem e transformam culturas de aprendizagem sejam elas favoráveis ou não. Dimensão sociológica que também auxiliou a compreensão e discussão do cenário da disciplina.

Os depoimentos dos alunos possibilitaram conhecer a realidade dos concluintes do ensino fundamental e regatar fatos que transcendem para outros campos do conhecimento devido à riqueza dos dados. Conforme a literatura e a experiência profissional, resultados confirmam o que se verifica em outros contextos escolares, como: "aula livre", conteúdos sem significados, ênfase na EF voltada ao esporte, alunos sem motivação e poucos motivados, relação com a saúde, professor como agente responsável por uma boa aula, participação e efetividade da gestão democrática.

O estudo possibilitou observar em relação aos objetivos que poucos dos entrevistados estão motivados intrinsecamente para a EF e que essa motivação depende de vários fatores, inclusive da realidade sociocultural em que vivem. Verificou-se que há certa motivação nos alunos já familiarizados com esporte ou atividades físicas, enquanto para outros ela é indiferente e até mesmo há aqueles alunos que não gostam. Boa parte da falta de interesse de alguns é originária da qualidade do conteúdo, da postura do professor e da falta de significado na prática. Assim, o significado da aula para alguns se resume em: "tempo livre" e esporte. Esses não parecem consistentes para provocar mudança na percepção e na atitude dos alunos perante a EF. 
Em vista disso, a motivação associa-se ao significado que o aluno proporciona à prática da disciplina. Caso ela agrade e faça sentido, tem-se o gosto pela aula. Em contrapartida, para outros alunos, o esporte não proporciona interesse, então, ocorre há resistência. Eles anseiam por mediação docente para conduzir atividades e esperam por uma aula diferenciada que não seja "livre" ou somente atividades repetitivas.

Mesmo com os significados atribuídos pelos alunos, é importante a relação da EF com a saúde (a qual a pesquisa também objetivou investigar) citada pelos alunos e confirmada por outros quando questionada. A melhora da saúde (por meio dos exercícios físicos) e o combate ao sedentarismo faz-se presente nos relatos, mesmo daqueles que não são adeptos às práticas da EF. Portanto, a saúde configura-se um fator favorável ao trabalho do professor, para (re)significar suas aulas e elevar o nível de motivação dos alunos. O estilo de vida saudável é o maior potencial da EF em seus objetivos atuais, mas é preciso reflexão sobre a prática em meio a essa relação e que conste no PPP da unidade escolar como ações e metas.

A partir do conceito de melhoria da saúde corporal é possível avançar e atingir outros significados, como: autonomia, cultura corporal, cooperação, e outros. Motivos extrínsecos serão transformados em intrínsecos, visto que a prática de exercícios é algo preventivo (à saúde) e poderia proporcionar benefícios como prazer e bem estar (gosto e motivo pelo que se realiza).

Portanto, a motivação se faz um dos maiores desafios para a EF escolar, bem como para todo o ensino. Manter o aluno motivado favoreceria o seu aproveitamento escolar em geral, seja na assimilação do conhecimento como na formação do cidadão. Em especial para a $\mathrm{EF}$, este estudo evidencia que a saúde é aliada ao combate do cenário desmotivador que se apresentou.

Durante a pesquisa, notou-se que os alunos pouco se expressam quando são entrevistados, talvez por timidez por não estarem acostumados a este tipo de situação e relação aluno-pesquisadores. Para auxiliar os dados que foram interpretados, poderia ter sido aplicado um questionário anterior ao diálogo para, juntamente com o roteiro, nortear a entrevista e o aluno explicaria o que respondeu com complementações.

Contudo, a experiência do momento com esses alunos traz reflexões importantes e deixa um legado, pois, dificilmente eles são ouvidos e suas opiniões consideradas (ensino tradicional e conservador). Para além das contribuições aos leitores fica a experiência para esses jovens que participaram e são protagonistas de futuras mudanças. Além disso, a importância que a gestão democrática destaca no trabalho a fim de promover mudanças na EF (e em todo o ensino). Foi possível perceber a importância do docente, da equipe gestora, da 
família (como incentivadora e participativa) e, principalmente, do aluno em promover melhoria na motivação das aulas, ou seja, um trabalho que envolve toda a comunidade escolar da instituição prevista no PPP e na legislação para garantir um ensino de qualidade.

Vale ressaltar que, mesmo ao corresponder favoravelmente aos objetivos, o trabalho é concluído e a pesquisa não se encerra. É preciso ainda mais estudos e investigações que envolvam outros alunos, instituições de ensino e até mesmo os pais e/ou responsáveis. Cada fator aqui apresentado desencadeia diversas possibilidades de estudo. Dentre elas é possível destacar: pesquisas na motivação dos docentes, na motivação para práticas esportivas, na participação familiar seja no esporte ou na vida escolar, a questão do capital cultural e social dos alunos para a prática de atividades físicas, o aprofundamento na relação EF e saúde dos alunos dentre outros. Portanto, em virtude do cenário motivacional apresentado, o trabalho fomenta investigações que contribuam e transformem a EF escolar na sociedade contemporânea. 


\section{REFERÊNCIAS}

ARELARO, L. R. G.; JACOMINI, M. A.; KLEIN, S. B. O ensino fundamental de nove anos e o direito à educação. Educação e Pesquisa, São Paulo, v.37, n.1, p. 35-51, 2011.

AZEVEDO, S. E.; SHIGUNOV, V. Reflexões sobre as abordagens pedagógicas de Educação Física. Revista Kinein, v. 1. n. 1, 2000.

BARKER-RUCHTI, N. et al. Learning cultures and cultural learning in high-performance sport: opportunities for sport pedagogues. Physical Educationand Sport Pedagogy. 2016.

BENTO, J. O. Conjuntura Corporal, Inatividade e Obesidade: Papel do Desporto e da Escola. In: MOREIRA, W.W. et al. (Org.). Educação Física, Esporte, Saúde e Educação. Uberaba, p.11-50, 2010.

BETTI, I. C. R. Esporte na escola: mas é só isso professor?. Motriz, São Paulo, v.1. n. 1, 25$31,1999$.

BETTI, M. Educação Física e sociedade. São Paulo: Movimento, 1991.

. Valores e finalidades na Educação Física Escolar: uma concepção sistêmica.

Revista Brasileira de Ciências do Esporte, v.16, n. 1, p. 14-21, 1994.

BETTI, M.; LIZ, M. T. F. Educação Física Escolar: a perspectiva de alunas do ensino fundamental. Motriz, Revista de Educação Física. UNESP, Rio Claro, v.9, n.3, p.135-142, 2003.

BETTI, M.; ZULIANI, L. R. Educação Física Escolar: Uma Proposta de Diretrizes Pedagógicas. Revista Mackenzie de Educação Física e Esporte, v. 1, n. 1, 2002.

BOURIDEU, P. Algumas propriedades dos campos. In: Questões de Sociologia. Rio de Janeiro: Marco Zero, 1983.

Razões práticas: sobre a teoria da ação. Campinas: Papirus, 1996.

. The forms of capital. In: RICHARDSON, J. (Ed.). Handbook of Theory and

Research for the Sociology of Education. New York: Greenwood, p. 241-258, 1986.

BRACHT, V. A constituição das teorias pedagógicas da educação física. Cadernos Cedes, ano 19, n. 48, 1999.

BRASIL. Casa Civil. Dispõe sobre o Estatuto da Criança e do Adolescente. Brasília, 1990.

Disponível em http://www.planalto.gov.br/ccivil_03/leis/L8069.htm. Acesso em: 20/07/2017.

. Lei de Diretrizes e Bases. Lei no 9.394/96, de 20 de dezembro de 1996.

. Secretaria de Educação Fundamental. Parâmetros curriculares nacionais:

Educação física / Secretaria de Educação Fundamental. Brasília: MEC/SEF, 96p,1997. 
. Secretaria de Educação Fundamental. Parâmetros curriculares nacionais: meio ambiente, saúde / Secretaria de Educação Fundamental. Brasília: MEC/SEF, 1997. 128p. . Presidência da República. Lei n. 11.274/2006. Brasília, 2006.

. Ministério da Educação. Conselho Nacional de Educação. Câmara de Educação Básica. Resolução CNE/SEB no . 3, de 3 de agosto de 2005.

BONI, V.; QUERESMA, S. J. Aprendendo a entrevistar: como fazer entrevistas em Ciências Sociais. Revista Eletrônica dos Pós-Graduandos em Sociologia Política da UFSC, v. 2, n. 1, p. 68-80, 2005.

BRAUN; V.; CLARKE, V. Using thematic analysis in psychology, Qualitative Research in Psychology, 3:2, p. 77-101, 2006.

BROTTO, F. O. Jogos Cooperativos: se o importante é competir, o fundamental é cooperar. São Paulo: Cepeusp, 1995.

COLETIVO DE AUTORES. Metodologia de ensino de educação física. São Paulo: Cortez, 1992.

CAMACHO, R. S.; ALMEIDA, R. A. Os Parâmetros Curriculares Nacionais (PCNs) do ensino fundamental em debate. Revista Formação, n. 15, v. 1, p. 36-60, 2008.

CAMPOS, D. F. et al. As dificuldades encontradas pelos professores de Educação Física no ensino fundamental da escola pública. EFDeportes.com, Revista Digital. Buenos Aires, Ano 19, n. 201, 2015.

CARVALHO, F. F. B. A saúde vai à escola: a promoção da saúde em práticas pedagógicas. Physis Revista de Saúde Coletiva, Rio de Janeiro, v. 25, n. 4, p. 1207-1227, 2015.

CASTELLANI FILHO, L. Educação física no Brasil: a história que não se conta. Campinas, SP: Papirus, 1988.

CASTRO, C. In corpore sano - os militares e a introdução da educação física no Brasil. Antropolítica, Niterói, n. 2, p. 61-78, 1997.

CAVALIERI, D. Educação Física no Ensino Médio. Por que o desinteresse dos alunos? EFDeportes.com, Revista Digital. Buenos Aires, ano 17, n. 170, 2012.

CLARKE, V.; BRAUM, V. Teaching thematic analysis: Overcoming challenges and developing strategies for effective learning. The Psychologist, v.2, n. 26, p. 120-123, 2013.

COSTA, F. S.; SILVA, J. L. L.; DINIZ, M. I. G. A importância da Interface Educação/Saúde no Ambiente Escolar como prática de promoção da saúde. Informe-se em promoção da saúde, v.4, n.2. p.30-33, 2008.

DAOLIO, J. Cultura, educação física e futebol. Campinas: Unicamp, 1997. 
DARIDO, S. C. A educação física na escola e o processo de formação dos não praticantes de atividade física. Revista Brasileira de Educação Física e Esporte, v. 18, n. 1, p. 61-80, 2004.

. Apresentação e análise das principais abordagens da educação física escolar. Revista Brasileira de Ciências do Esporte, 20 (1), Setembro/1998. $\overline{\text { Koogan, } 2003 .}$

Educação física na escola: questões e reflexões. Rio de Janeiro: Guanabara

Os conteúdos da Educação Física na escola. Rio de Janeiro: Guanabara Koogan, 2005, p. 64-79.

DARIDO, S.C; SOUZA JÚNIOR, O. M. Para ensinar educação física: possibilidades de intervenção na escola. Campinas: Papirus, 2015.

FARIAS, W. L. S. et al. Educação Física escolar nos anos finais do ensino fundamental e a prática de atividades físicas fora da escola. Revasf, Petrolina-PE, v. 7, n.12, p. 163-176, 2017.

FERRAZ, O. L.; CORREIA, W. R. Teorias curriculares, perspectivas teóricas em Educação Física escolar e implicações para formação docente. Revista Brasileira Educação Física e Esporte, São Paulo, v.26, n.3, p.531-540, 2012.

FERREIRA, M. S. Aptidão Física e Saúde na Educação Física Escolar: Ampliando o enfoque. Revista Brasileira Ciências Esporte, v. 22, n. 2, p. 41-54, 2001.

FOLLE, A.; TEIXEIRA, F. A. Motivação de Escolares das Séries Finais do Ensino Fundamental nas Aulas de Educação Física. Revista Educação Física/UEM, v. 23, n. 1, p. 37-44, 2012.

FREIRE, J. B. Educação de corpo inteiro. Teoria e prática da Educação Física. Campinas: Scipione, 1989.

GIL, Antônio Carlos. Métodos e técnicas de pesquisa. 6. ed. - São Paulo: Atlas, 2008.

GUEDES, D. P. Educação para a saúde mediante programas de Educação Física escolar. Motriz, Revista de Educação Física. Rio claro, v. 5, n. 1, p. 10-14, 1999.

GUEDES, D. P.; GUEDES, J. E. R. P. Subsídios para implementação de programas direcionados à promoção da saúde através da Educação Física Escolar. Revista da APEF. Londrina, v. 8, n.15 p. 3-11, 1993.

GUIMARÃES, C. C. P. A. Educação Física escolar e promoção da saúde: uma pesquisa participante. 2009. 156f. (Texto de dissertação de mestrado) - Universidade de São Judas Tadeu, São Paulo, SP.

HILDEBRANDT-STRAMANN, R. Textos pedagógicos sobre o ensino da Educação Física. Ijuí: Unijuí, 2003. 
HODKINSON P.; BIESTA, G. J. J.; JAMES, D. Learning Cultures and a Cultural Theory of Learning. In: JAMES, D., BIESTA, G. Improving Learning Cultures in Further

Education. Improving Learning, New York and London: Routledge, p. 21-37, 2007. . Understanding learning culturally: overcoming the dualism between social and individual views of learning, Vocations and Learning, n.1, v. 1, p. 27-47, 2008.

JACO, J. F. Educação Física Escolar e Gênero: Diferentes maneiras de participar das aulas. 2012. 120f. (Texto de dissertação de mestrado em Educação Física) - Faculdade de Educação Física. Universidade Estadual de Campinas, Campinas.

KOBAL, M. C. Motivação intrínseca e extrínseca nas aulas de educação física. 1996. 176f. (Texto de dissertação de mestrado) - Universidade Estadual de Campinas, Faculdade de Educação Física, Campinas.

LIMA, L. B. Q. et al. A Ginástica Artística na proposta curricular para a Educação Física em São Paulo. Pensar a Prática, Goiânia, v. 18, n. 2, 2015.

KUNZ, E. Transformação didático-pedagógica do esporte. $6^{\text {a }}$ ed. Ijuí: Unijuí, 2004.

LE BOULCH, J. O desenvolvimento psicomotor: do nascimento até 6 anos. Porto Alegre: Artes Médicas, 1992.

MAGILL, R. A. Aprendizagem Motora: Conceitos e Aplicações. São Paulo: Edgard Blücher, 1984.

MARCHINI, A. C.; ARMBRUST, I. Educação Física e sua influência fora da escola: Opinião de alunos do Ensino Médio. Coleção Pesquisa em Educação Física, v. 11, n. 4, 2012.

MARTINELLI, C. R. et al. Educação física no ensino médio: motivos que levam as alunas a não gostarem de participar das aulas. Revista Mackenzie de Educação Física e Esporte, São Paulo, v. 5, n. 2, p. 13-19, 2006.

MARZINEK, A. A motivação de adolescentes nas aulas de Educação Física. 2004. 89f. (Texto de dissertação de mestrado) - Universidade Católica de Brasília, Programa de Pósgraduação Strictu Sensu em Educação Física, Brasília, DF.

MONTEIRO, A. M. P.; NAVARRO, A. C. Prevalência de obesidade em crianças e adolescentes do ensino fundamental numa cidade do interior de Minas Gerais. Revista Brasileira de Obesidade, Nutrição e Emagrecimento, São Paulo, v. 5, n. 28, p. 272-6, 2011.

MOREIRA, E. C. Educação física escolar: desafios e propostas 1. 2 ed. - Jundiaí, SP: Fontoura, 2009.

MATTOS, M. G.; NEIRA, M. G. Educação Física na adolescência: construindo o conhecimento na escola. São Paulo: Phorte, 2000. 
NAHAS, M. V. Educação Física no Ensino Médio: educação para um estilo de vida ativo no terceiro milênio. Anais do IV Seminário de Educação Física Escolar / Escola de Educação Física e Esportes, p.17-20, 1997.

NASCIMENTO, B. B.; GARCES, S. B. B. Educação Física ou rola a bola? A percepção da comunidade escolar sobre as aulas de Educação Física. EFDeportes.com, Revista Digital, Buenos Aires, Ano 17, n. 178, 2013.

NEIRA, M. G. Teorias pós-críticas da educação: subsídios para o debate curricular da Educação Física. Dialogia, São Paulo, n. 14, p. 195-206, 2011.

NEVES, J. L. Pesquisa Qualitativa - Característica, Usos e Possibilidades. Caderno de Pesquisas em Administração, São Paulo, v.1, n. 3, 1996.

NETO, A. R. M. et al. Evasão escolar e desinteresse dos alunos nas aulas de Educação Física. Pensar a Prática, Goiânia, v. 13, n. 2, p. 115, 2010.

NETO, J. J. S.; TEIXEIRA, R. F. Monitorando o ambiente escolar para a Educação Física no ensino fundamental. Estudos Avaliação Educacional, São Paulo, v. 28, n. 69, p. 686-717, 2017.

NICHOLLS, J. G. Achievement Motivation: Conceptions of Ability, Subjective Experience, Task Choice, and Performance. Psychological Review, v. 91, n. 3, 328-346, 1984.

NISTA-PICCOLO, V. L.; MOREIRA, W. W. Esporte como Conhecimento e Prática nos anos iniciais do Ensino Fundamental. $1^{\circ}$ ed. São Paulo: Cortez, 2012.

NOBRE, G. C. et al. Conteúdos aplicados na Educação Física em escolas da cidade Juazeiro do Norte, Ceará. EFDeportes.com Revista Digital, Buenos Aires - Ano 14, n. 134, 2009.

NUNOMURA, M.; OLIVEIRA, M. S. A participação dos pais na carreira das atletas femininas de ginástica artística: a perspectiva dos técnicos. Revista Brasileira Educação Física e Esporte, São Paulo, 2014.

OLIVEIRA, A. R. et al. A promoção da saúde e qualidade de vida na educação básica: Um olhar na educação física que temos para a educação física que queremos. Anais do II

CONPEF - Congresso Norte Paranaense de Educação Física Escolar, p. 103 - 116, 2005.

OLIVEIRA, P. P. Illusio: aquém e além de Bourdieu. Mana, v.11 n. 2, Rio de Janeiro, 2005.

OLIVEIRA, S.A. Reinventando o esporte: possibilidade da prática pedagógica.

Campinas: Autores Associados, 2001.

Organização Mundial da Saúde. Problemas de la salud de la adolescencia. Informe de un comité de expertos de la O.M.S (Informe técnico n 308). Genebra, 1965

PEREIRA, L. A. A.; SILVA, M. C. A aplicação do conteúdo ginástica nas aulas de Educação Física escolar no município de Araruna, PR. EFDeportes.com, Revista Digital. Buenos Aires, Ano 15, n. 148, 2010. 
PEREIRA, M. G. R. A motivação de adolescentes para a prática da Educação Física: uma análise comparativa entre instituição pública e privada. 2006. 109f. Dissertação (Mestrado em Educação Física) - Universidade São Judas Tadeu, São Paulo.

PEREZ, L. et al. Motivación de logro eneducación física escolar: um estudio comparativo entre cinco paises. Revista de Educación, n. 333, p. 345-361, 2004.

PIMENTA, T.; HONORATO, T. Esporte moderno e mediação pedagógica nas aulas de educação física. Revista brasileira Educação Física Esporte, São Paulo, v. 24, n. 4, p. 493-505, 2010.

PINTO, J. M. R. Os prováveis efeitos dos exames padronizados e do IDEB na política educacional. In: PINHO, S. Z. (Org.). Formação de Educadores: dilemas contemporâneos. São Paulo: Editora da UNESP, 2011.

PRANDINA, M. Z.; SANTOS, M. L. A Educação Física escolar e as principais dificuldades apontadas por professores da área. Horizontes - Revista de Educação, Dourados - MS, v.4, n.8, 2016.

RANGEL-BETTI, I. C. Educação Física escolar: a preparação discente. Revista Brasileira de Ciências do Esporte. Campinas, nº 16 (3), p. 158-167, 1995.

REEVE, J. Autonomy support as an interpersonal motivating style: Is it teachable?

Contemporary Educational Psychology, n. 23, p.312-330, 1998.

RESENDE, D. M. S. Sentidos e significados da promoção da saúde na educação física escolar (Trabalho de conclusão de curso). Goiânia: Universidade Federal de Goiás, Curso de Licenciatura Plena em Educação Física, 2013.

ROCHA, C., C. M. A motivação de adolescentes do ensino fundamental para a prática da Educação Física escolar. 2009. 104f. (Texto de Dissertação de Mestrado em Psicologia do Desporto) - Universidade Técnica de Lisboa - Faculdade de Motricidade Humana, Lisboa, PT.

RYAN, R. M.; DECI, E. L. Intrinsic and Extrinsic Motivations: Classic Definitions and New Directions. Contemporary Educational Psychology. v. 25, p. 54-67, 2000.

. The darker and brighter sides of human existence: basic psychological needs as a unifying concept. Psychological Inquiry, n. 11, v. 4, p. 319-338, 2000 b.

SALLES, L. M. F. Infância e adolescência na sociedade contemporânea: alguns apontamentos. Estudos psicologia, Campinas, v. 22, nº. 1, 2005.

SAMULSKI, D. M. Psicologia do esporte. $1^{\text {a }}$ ed. brasileira. Barueri: SP. Ed. Manole, 2002.

SANTOS, R. M.; DUQUE, L. F. Evasão na aula de Educação Física: fatores que interferem na participação do aluno. EFDeportes.com, Revista Digital. Buenos Aires, Ano 15, n. 149, 2010 . 
SÃO PAULO (ESTADO). Proposta Curricular do Estado de São Paulo: Educação Física / Coord. Maria Inês Fini - São Paulo: SEE, 2008.

. Secretaria da Educação. Currículo do Estado de São Paulo: Linguagens, códigos e suas tecnologias / Secretaria da Educação; coordenação geral, Maria Inês Fini; coordenação de área, Alice Vieira. - 2. ed. - São Paulo: SE, 260 p., 2011.

. Secretaria da Educação do Estado de São Paulo. Resolução SE no 81 de 16 de dezembro de 2011. Estabelece diretrizes para a organização curricular do ensino fundamental e do ensino médio nas escolas estaduais. Disponível em: $<$ http://siau.edunet.sp.gov.br/ItemLise/arquivos/81_11.HTM>. Acesso em: 28/07/17.

SECRETARIA DA EDUCAÇÃO. Referencial Curricular: Ensino Fundamental - Anos Iniciais / Coord. Maria Ângela S. Sordi Marchi - Ribeirão Preto: Secretaria Municipal da Educação, 2011.

. Referencial Curricular: Ensino Fundamental - Anos Finais / Coord. Luciana Menna Barreto Gasparini - Ribeirão Preto: Secretaria Municipal da Educação, 2017.

SEVERINO, C. D.; ADRIANO, L. G. Pontos divergentes da Educação Física em escolas públicas e privadas: a visão de professores do ensino superior. Cadernos Unifoa, Ed. 28, 2015 .

SEVERINO, C. D.; SILVA, B. M. Educação Física escolar e a promoção da saúde: um ponto de vista. Caderno de Educação Física e Esporte, Marechal Cândido Rondon, v. 12, n. 2 , p. 77-86, 2014.

SCHOEN-FERREIRA, T. H.; AZNAR-FARIAS, M. Adolescência através dos séculos. Psicologia: Teoria e Pesquisa, v. 26, n. 2, p. 227-234, 2010.

SILVA, A. T. et al. Conhecimento sobre as abordagens pedagógicas da Educação Física: escola estadual x escola particular. EFDeportes.com, Revista Digital. Buenos Aires, Ano 15, n. $151,2010$.

SILVA, M. M. Razões da Desmotivação nas aulas de Educação Física no Ensino Médio. Monografia (Especialização em Educação Física Escolar) - Universidade do Extremo Sul Catarinense - UNESC, SC, 2010.

SOARES, C. L. Educação Física: raízes europeias e Brasil. $4^{\mathrm{a}}$ ed. Campinas: Autores Associados, 2007.

SOUZA JUNIOR, M. B. M.; MELO, M. S. T.; SANTIAGO, M. E. A análise de conteúdo como forma de tratamento dos dados numa pesquisa qualitativa em Educação Física escolar. Movimento, Porto Alegre, v. 16, n. 03, p. 31-49, 2010.

SOUZA, F. T. R.; PAGANI, M. M. A Educação Física Escolar do Ensino Médio: A Ótica do Aluno. Educação, Cultura e Sociedade, Sinop, v. 2, n. 2, p.109119, 2012. 
TANI, G. et al. Educação Física Escolar: fundamentos de uma abordagem desenvolvimentista. São Paulo: EPU: Editora da Universidade de São Paulo, 1988.

TAYLOR, I. M.; NTOUMANIS, N. Teacher Motivational Strategies and Student SelfDetermination in Physical Education. Journal of Educational Psychology, v. 99, n. 4, p. 747-760, 2007.

TEIXEIRA, R. F. Avaliação do ambiente escolar para o ensino e prática da Educação Física no ensino fundamental. 2015. 119f. (Texto de dissertação de Mestrado em Desenvolvimento, Sociedade e Cooperação Internacional) - Universidade de Brasília, Brasília, DF.

TENORIO, J. G.; SILVA, C. L. Educação Física escolar e a não participação dos alunos nas aulas. Ciência em Movimento, Ano 15, n. 31, 2013.

TENORIO, M. C. M.; TASSITANO, R. M.; LIMA, M. C. Conhecendo o ambiente escolar para as aulas de educação física: existe diferença entre as escolas?. Revista Brasileira Atividade Física e Saúde, Pelotas/RS, n. 17, v. 4, p. 307-313, 2012.

THIRY-CHERQUES, H. R. Pierre Bourdieu: a teoria na prática. RAP, Rio de Janeiro, v. 1, n 40, p. 27-55, 2006.

TODOROV, J. C.; MOREIRA, M. B. O Conceito de Motivação na Psicologia. Revista Brasileira de Terapia Comportamental e Cognitiva. v. 7, n. 1, p. 119-132, 2005.

TRESCA, R.; DE ROSE JR, D. Estudo comparativo da motivação intrínseca em escolares praticantes e não praticantes de dança. Revista Brasileira de Ciência e Movimento, Brasília, v. 8, n. 1, p. 9-13, 2000.

TRIVINOS, A.N.S. Introdução à pesquisa em ciências sociais. São Paulo: Atlas, 1992.

TOLEI, G. G.; MANZINI, E. J. Etapas da Estruturação de um Roteiro de Entrevista e Considerações Encontradas Durante a Coleta dos Dados. VIII encontro da associação brasileira de pesquisadores em educação especial, Londrina, 2013.

VAGO, T. M. Início e fim do século XX: Maneiras de fazer a educação física na escola. Cadernos Cedes, ano 19, n. 48, 1999.

VIANNA, A. J. C. et al. Significado da prática esportiva extracurricular para os pais. Arquivos em Movimento, v.13, n.1, p.21-31, 2017.

VILANI, L. H. P; SAMULSKI, D. M. Família e Esporte: uma revisão sobre a influência dos pais na carreira esportiva de crianças e adolescentes. In: SILAMI GARCIA, E.; LEMOS, K. L. M. Temas Atuais VII: Educação Física e Esportes, Belo Horizonte: Editora Health, p. 09-26, 2002.

WEINBERG, R.S.; GOULD, D. Fundamentos da Psicologia do Esporte e do Exercício. $2^{\circ}$ Ed. Porto Alegre: Artmed, 2001.

WEINER, B. An atribucional theory of ach and emotion. Psychological Review, v. 4, n. 92, 1985. 
WITTER, G. P., LOMONACO, J. F. B. Psicologia da Aprendizagem. São Paulo: Editora Pedagógica e Universitária Ltda., 1984.

ZABALA, A. A prática educativa: como ensinar. Porto Alegre: Artmed, 1998. 
ANEXOS

ANEXO A

Parecer Consubstanciado do Comitê de Ética e Pesquisa

USP - ESCOLA DE EDUCAÇÃO
FÍSICA E ESPORTE DE
RIBEIRÃO PRETO DA USP

PARECER CONSUBSTANCIADO DO CEP

\section{DADOS DO PROJETO DE PESQUISA}

Título da Pesquisa: CONSCIENTIZAÇÃO DA SAÚDE CORPORAL, MOTIVAÇÃO E EDUCAÇÃO Fí́SICA ESCOLAR NO ENSINO FUNDAMENTAL

Pesquisador: Myrian Nunomura

Área Temática:

Versão: 1

CAAE: 63949717.4 .0000 .5659

Instituição Proponente:UNIVERSIDADE DE SAO PAULO

Patrocinador Principal: Financiamento Próprio

DADOS DO PARECER

Número do Parecer: 1.938 .879

Apresentação do Projeto:

Será desenvolvida uma pesquisa de campo em uma escola pública da cidade de Ribeirão Preto/SP.Fssa pesquisa será qualitativa, isto é, não estará

preocupada com a mensuração quantitativa dos dados coletados. O intuito nesse tipo de pesquisa é analisar e interpretar os dados analisados,

contextualizando-os e sem necessidade de generalizar (TRIVINOS, 1992). Além disso, a pesquisa nos permite conhecer o contexto recortado a

partir do depoimento dos sujeitos. Participarão da pesquisa alunos regularmente matriculados no $9^{\circ}$ ano do Ensino Fundamental, com faixa etária

entre 14 e 15 anos. Para as entrevistas serão selecionados dentre todos os alunos da sala aqueles (meninos e meninas) que iniciaram seus estudos

na referida escola desde o $1^{\circ}$ ano do Ensino Fundamental. Caso o número ainda se faça muito elevado será priorizado aquele que tiver a idade de

14 anos. Todos os alunos receberão o Termo de Livre Consentimento Esclarecido (TLCE) para seus responsáveis assinarem e também o Termo de

Assentimento Livre Esclarecido (TALE) para que por eles próprios sejam assinados, concordando com sua participação na pesquisa. Para a coleta

Endereço: Avenida Bandeirantes, 3900

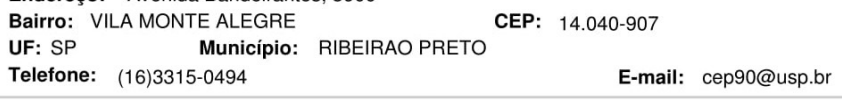




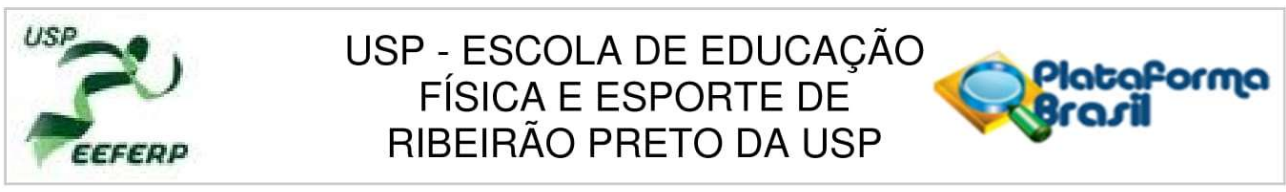

Continuação do Parecer: 1.938 .879

de dados serão realizadas entrevistas que segundo Gil (2008) possibilita ter um contato com a realidade vivida pelos atores, e uma forma flexível

para coleta. Serão feitas perguntas diretas para permitir que 0 aluno fale livremente sobre suas aulas de Educação Fisica, podendo em alguns

momentos haver outras indagações sobre temas que surjam. Em um primeiro momento, e para reconhecimento do público na sala escolhida do 9은

ano, será feita uma observação de todos os alunos em algumas aulas de Educação Física. As entrevistas serão gravadas e transcritas. Os dados

serão tratados da forma categorial temática sendo feito uma pré-análise, exploração do material e por fim o tratamento dos dados e interpretação

(BARDIN, 2010). Por fim, iremos confrontas os resultados das entrevistas, com as propostas da Educação Física escolar para essa faixa etária,

outros estudos realizados e entender a motivação dos alunos e sua possível relação com a conscientização da saúde corporal. Cronograma: $O$

projeto de pesquisa será executado após a aprovação do CEP (de acordo com a carta circular 061/2012 CONEP).

\section{Objetivo da Pesquisa:}

Objetivos Gerais: Analisar a relação entre a conscientização para a saúde e a motivação para a as aulas de Educação Física escolar no ensino

fundamental. Objetivos Específicos: Identificar fatores positivos e negativos que impactam no nível de motivação para as aulas de Educação Física

escolar; indicar propostas/direcionamentos para elevar o nível de motivação para as aulas de Educação Física escolar.

\section{Avaliação dos Riscos e Benefícios:}

Os riscos e benefícios inerentes a pesquisa foram descritos corretamente.

Comentários e Considerações sobre a Pesquisa:

O projeto foi apresentado com clareza e objetividade.

Considerações sobre os Termos de apresentação obrigatória:

Todos os termos foram apresentados.

\section{Recomendações:}

O projeto foi apresentado com clareza e objetividade, além de estar com toda a documentação presente.

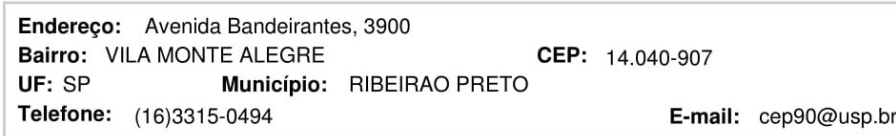




USP - ESCOLA DE EDUCAÇÃO
FÍSICA E ESPORTE DE
RIBEIRÃO PRETO DA USP

Continuação do Parecer: 1.938 .879

Conclusões ou Pendências e Lista de Inadequações:

Nada a relatar.

Considerações Finais a critério do CEP:

O projeto encontra-se APROVADO para execução. Pedimos atenção aos seguintes itens:

1) De acordo com a Resolução CNS n. $0466 / 2012$, o pesquisador deverá apresentar relatórios semestrais (parciais e final, em função da duração da pesquisa);

2) Eventuais emendas (modificações) ao protocolo devem ser apresentadas, com justificativa, ao CEP de forma clara e sucinta, identificando a parte do protocolo a ser modificada. Neste caso, o pesquisador deve aguardar nova aprovação do CEP para realizar os procedimentos de acordo com as mudanças solicitadas; 3) Sobre o TCLE: caso o termo tenha DUAS páginas ou mais, lembramos que no momento da sua assinatura, tanto o participante da pesquisa (ou seu representante legal) quanto o pesquisador responsável deverão RUBRICAR todas as folhas, colocando as assinaturas na última página;

4) Caso haja instituição(ões) coparticipante(s) no projeto, atender a solicitação da carta $n$. 응 0212/CONEP/CNS, de 21 de outubro de 2010.

Este parecer foi elaborado baseado nos documentos abaixo relacionados:

\begin{tabular}{|c|c|c|c|c|}
\hline Tipo Documento & Arquivo & Postagem & Autor & Situação \\
\hline $\begin{array}{l}\text { Informações Básicas } \\
\text { do Projeto }\end{array}$ & $\begin{array}{l}\text { PB_INFORMAÇŌES_BÁSICAS_DO_P } \\
\text { ROJETO 853008.pdf }\end{array}$ & $\begin{array}{l}18 / 01 / 2017 \\
09: 47: 07\end{array}$ & & Aceito \\
\hline $\begin{array}{l}\text { TCLE / Termos de } \\
\text { Assentimento / } \\
\text { Justificativa de } \\
\text { Ausência } \\
\end{array}$ & TALE_Alunos.pdf & $\begin{array}{c}17 / 01 / 2017 \\
13: 47: 05\end{array}$ & $\begin{array}{l}\text { EDUARDO } \\
\text { HENRIQUE DE } \\
\text { OLIVEIRA }\end{array}$ & Aceito \\
\hline $\begin{array}{l}\text { TCLE / Termos de } \\
\text { Assentimento / } \\
\text { Justificativa de } \\
\text { Ausência }\end{array}$ & TCLE_Responsavel.pdf & $\begin{array}{c}17 / 01 / 2017 \\
13: 46: 53\end{array}$ & $\begin{array}{l}\text { EDUARDO } \\
\text { HENRIQUE DE } \\
\text { OLIVEIRA }\end{array}$ & Aceito \\
\hline $\begin{array}{l}\text { Projeto Detalhado / } \\
\text { Brochura } \\
\text { Investigador }\end{array}$ & ProjetoPesquisaDetalhado.docx & $\begin{array}{c}17 / 01 / 2017 \\
13: 46: 44\end{array}$ & $\begin{array}{l}\text { EDUARDO } \\
\text { HENRIQUE DE } \\
\text { OLIVEIRA }\end{array}$ & Aceito \\
\hline Outros & Roteiro_Entrevista.pdf & $\begin{array}{l}15 / 01 / 2017 \\
21: 36: 52\end{array}$ & $\begin{array}{l}\text { EDUARDO } \\
\text { HENRIQUE DE } \\
\text { OLIVEIRA }\end{array}$ & Aceito \\
\hline Outros & AutorizacaoPesquisa.pdf & $\begin{array}{l}15 / 01 / 2017 \\
21: 35: 31\end{array}$ & $\begin{array}{l}\text { EDUARDO } \\
\text { HENRIQUE DE }\end{array}$ & Aceito \\
\hline
\end{tabular}

Endereço: Avenida Bandeirantes, 3900

Bairro: VILA MONTE ALEGRE

UF: SP Município: RIBEIRAO PRETO

CEP: $14.040-907$

Telefone: (16)3315-0494

E-mail: cep90@usp.br 


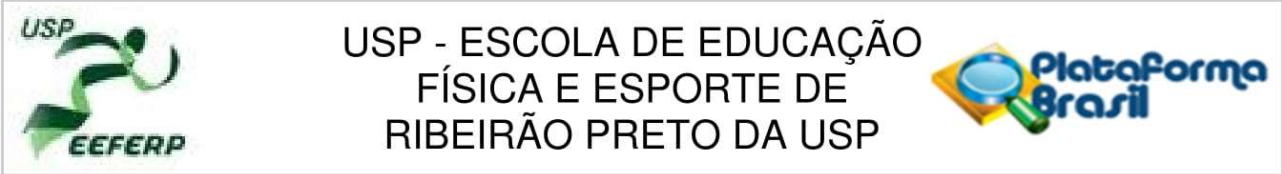

Continuação do Parecer: 1.938 .879

\begin{tabular}{|l|l|c|l|r|}
\hline Outros & AutorizacaoPesquisa.pdf & $\begin{array}{c}15 / 01 / 2017 \\
21: 35: 31\end{array}$ & OLIVEIRA & Aceito \\
\hline Folha de Rosto & FolhaRostoAssinada.pdf & $15 / 01 / 2017$ & EDUARDO & Aceito \\
& & $21: 32: 54$ & HENRIQUE DE & \\
& & & \\
& & & \\
\hline
\end{tabular}

Situação do Parecer:

Aprovado

Necessita Apreciação da CONEP:

Não

RIBEIRAO PRETO, 22 de Fevereiro de 2017

Assinado por:

Carlos Roberto Bueno Júnior

(Coordenador)

Endereço: Avenida Bandeirantes, 3900

Bairro: VILA MONTE ALEGRE

CEP: $14.040-907$

UF: SP

Município: RIBEIRAO PRETO

Telefone: (16)3315-0494

E-mail: cep90@usp.br

Página 04 de 04 


\section{ANEXO B}

\section{Roteiro de Entrevistas}

Nome do aluno:

Idade:

Endereço:

O presente roteiro será aplicado após assinatura do Termo de Consentimento Livre e Esclarecido por parte dos responsáveis e do Termo de Assentimento Livre e Esclarecido por parte do entrevistado.

Inicialmente será apresentada ao aluno a trajetória do entrevistador (pesquisador Eduardo) na Educação Física durante sua vida acadêmica. Esse exemplo pode ajudar a deixar o aluno mais a vontade para expressar suas experiências e opiniões no momento das perguntas. Estima-se cerca de 10 minutos para essa exposição da experiência do pesquisador.

*As perguntas nos subitens serão realizadas se necessário conforme o desenvolvimento da fala do aluno.

1. Fale o que as aulas Educação Física representam para você?

1.1. Se não prática, por quê?

1.2. Caso não goste, por quê?

1.3. Participa ativamente das aulas? Classifique a participação.

2. O que você mais gosta da aula? Caso não goste ou não pratique o que falta para você participar da aula?

3. Quais conteúdos você menos gosta e por quê?

4. Você acha que falta algo em sua aula de Educação Física? O que?

5. Como é a relação com seu professor de Educação Física?

6. Tem algum esporte preferido? Qual? Por quê?

6.1. Pratica esse esporte? Onde? Possui custo?

6.2. Na família tem algum esportista?

6.3. Sua família apoia sua prática? Incentiva?

7. Seus pais (responsáveis) ou alguém da família incentiva você a praticar esportes? O que acham de sua participação nas aulas de Educação Física? (Pergunta realizada caso o aluno não aprecie as aulas e não pratique atividade física).

8. Você acha importante a prática de atividade física? Por quê? (pergunta provocativa caso o aluno não mencione a importância da atividade física na saúde).

8.1. E as aulas de Educação Física como você relaciona com essa importância de se praticar um exercício físico?

9. O que mais lhe motiva a praticar atividade física? Ou o que a desmotiva a não praticar caso não pratique? 